\section{Evolución constructiva de Santa Eulalia de Bóveda (Lugo, Galicia)}

\section{Building sequence of Santa Eulalia de Bóveda (Lugo, Galicia)}

Rebeca Blanco-Rotea*

Laboratorio de Patrimonio (LaPa) - CSIC

Rosa Benavides García

TOMOS Conservación y Restauración, S.L.

Jorge Sanjurjo Sánchez

Instituto Universitario de Xeoloxía «Isidro Parga Pondal».

Universidade da Coruña

Daniel Fernández Mosquera

Instituto Universitario de Xeoloxía «lsidro Parga Pondal».

Universidade da Coruña

\section{Resumen}

El conjunto monumental de Santa Eulalia de Bóveda (Lugo, Galicia) es una de las arquitecturas más emblemáticas, pero también problemáticas, del patrimonio lucense. Desde su descubrimiento en el año 1926 muchos han sido los investigadores que han analizado el edificio desde un punto de vista arquitectónico, arqueológico, artístico e incluso simbólico, aportando variadas interpretaciones sobre este conjunto. Sin embargo, todavía no existe un consenso sobre su cronología, su funcionalidad o su evolución constructiva. Este texto corresponde a los trabajos realizados en Bóveda desde tres puntos de vista: el análisis de su arquitectura, el análisis de su decoración y la búsqueda de unos métodos de datación absoluta; y pretende ser una reflexión sobre los resultados obtenidos, una apuesta de futuro y un llamamiento sobre la necesidad de trabajar de forma conjunta entre profesionales de distintos campos disciplinares.

Palabras Clave: arquitectura tardorromana; arquitectura altomedieval; abovedamiento; pintura mural; decoración arquitectónica; luminiscencia; datación absoluta.

\section{Abstract}

The monumental complex of Santa Eulalia de Bóveda (Lugo, Galicia) is one of the most emblematic, but also most problematic, architectural works of the building heritage of Lugo. Since it was discovered in 1926, many researchers have analysed this building from an architectonical, archaeological, artistic and even symbolic point of view, providing several different interpretations of it. However, there is still no consensus about its chronology, its utility or its constructive evolution. This paper focus on the works carried out in Bóveda from three points of view: the analysis of its architecture, of its decoration, and the search for methods for absolute dating. It intends also to reflect on the outcome, to propose a commitment for the future, and to point out the necessity for professionals from different researching fields to work together.

Keywords: Late roman architecture; Early medieval architecture; vaulting; wall paint; architectonic decoration; luminescence; absolute dating.

\footnotetext{
* rebeca.blanco-rotea@iegps.csic.es; rosabenavides@mundo-r.com; jsanjurjo@udc.es; xemos@udc.es
}

De todos modos, este trabajo no se trata de un producto acabado. Cada tratado, cada edificio al que se hace referencia, cada autor, cada idea, expone ante nosotros un universo propio, rico y complejo donde transcurren tantas sugerencias como son posibles. Esta investigación, como concluimos lo pueden ser todas, es en el fondo una provocación para continuar recorriendo por el espacio de las ideas y en nuestro caso, por el espacio de la técnica; el mismo que desde hace muy pocos años se ha venido desenrollando y extendiendo sobre nosotros como cuando se corta por su eje una cinta de Moëbius.

Galindo Díaz (1996)

\section{UN EDIFICIO COMPLICADO}

Santa Eulalia de Bóveda es el clásico ejemplo de una arquitectura por la que han pasado diversos investigadores que la analizaron desde distintos campos disciplinares. Este hecho ha confluido en una gran disparidad interpretativa, tanto desde el punto de vista funcional como cronológico, que ha llevado a encuadrar Santa Eulalia como un ninfeo tardorromano o un edificio cristiano asturiano, con toda una serie de variantes entre ellos. De ello se puede hacer una primera lectura, que podríamos resumir de la siguiente manera: en este monumento están presentes técnicas, materiales, formas y decoraciones que se pueden relacionar tanto con el mundo romano como con el paleocristiano o

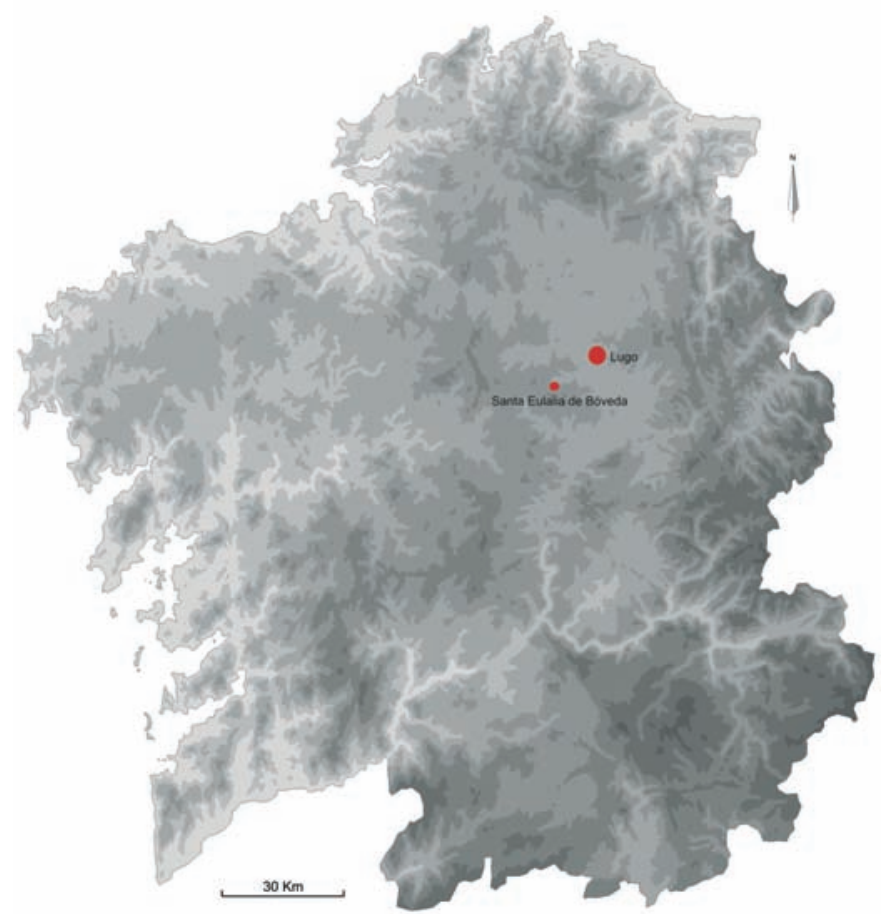

Fig. 1. Mapa de Galicia con la situación del pueblo de Santa Eulalia de Bóveda de Mera (Lugo) 


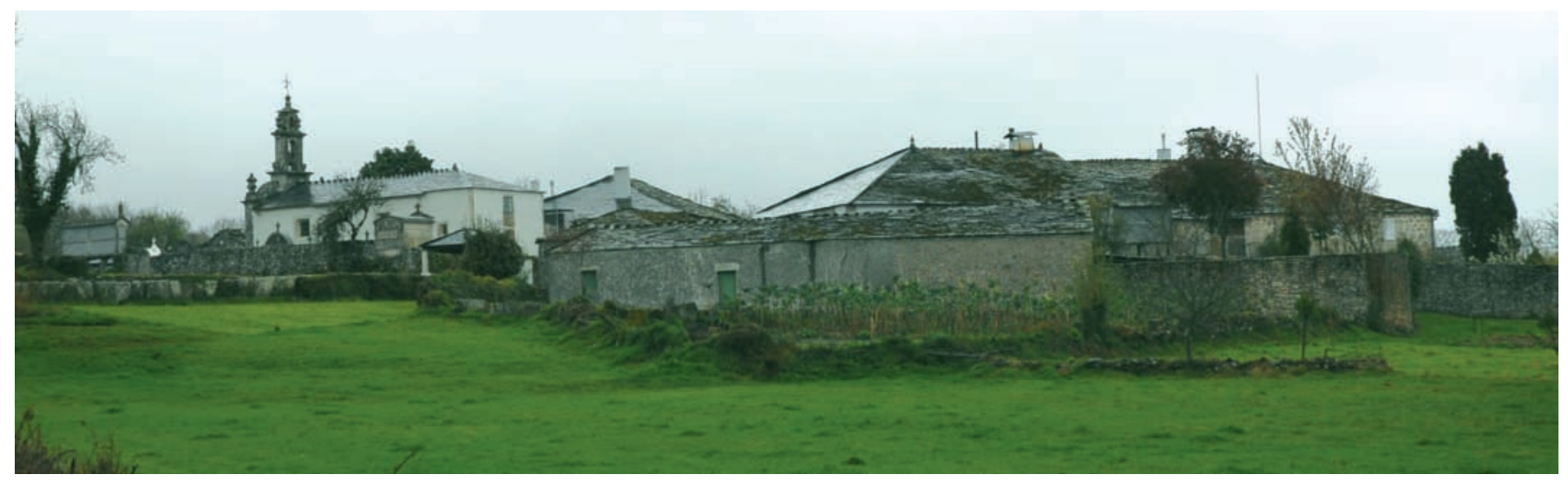

Fig. 2. El pueblo de Santa Eulalia de Bóveda de Mera (Lugo). Debajo de la iglesia se localiza el monumento

el altomedieval. De este modo, cada autor ha maximizado aquellos de estos aspectos que ha considerado que tenían un mayor peso dentro del edificio, contribuyendo a primar una u otra interpretación.

Si a ello añadimos la cantidad de datos que se han ido sumando y, a la vez, perdiendo desde su descubrimiento, con las aportaciones de diferentes autores, con las distintas intervenciones o las restauraciones más o menos acertadas, nos encontramos con un edificio al que hay que incorporar una memoria reciente que debe tenerse en cuenta en su actual lectura. Memoria que empieza en 1929 y finaliza en el 2007, posiblemente con solución de continuidad en el tiempo.

Pongamos como ejemplo las pinturas analizadas in situ y los fragmentos de estas que recientemente se revisaron en el Museo Provincial de Lugo para la elaboración del presente artículo. La diferencia de color o del tratamiento superficial que se observa entre ambas nos habla de que en las pinturas de la bóveda que se conservan in situ ha sucedido toda una serie de procesos naturales y antrópicos que han afectado a su estado de conservación tal y como se encontraban en la fecha de su descubrimiento. Se hacía necesario leer entre las líneas del documento, como quien trascribe un texto que ha perdido algunas de sus letras, intentando interpretar la escritura inicial. Por todo esto, cuando se nos planteó el estudio del conjunto monumental de Santa Eulalia de Bóveda suponía, por un lado, una responsabilidad y, por otro, un compromiso.

Como comentábamos arriba uno de los problemas de este edificio está directamente relacionado con su origen que unos autores sitúan en época tardorromano y otros en época altomedieval; todavía hoy resulta difícil responder a esta cuestión.

Nuestra intención en este texto era poner sobre el papel todos aquellos datos que hemos analizado y que nos parecen interesantes para continuar el trabajo en Santa Eulalia. Como en la cita con la que se abre este artículo esta investigación es en el fondo una provocación para continuar recorriendo por el espacio, en este caso, de Santa Eulalia. Emulando el título de una reciente e interesante publicación ${ }^{1}$ no pretendemos más que poner Santa Eulalia frente a Santa Eulalia.

En este sentido, cuando nos propusimos volver a escribir sobre este edificio, nuestra intención era doble. Por un lado, considerábamos que era necesario dar a conocer las conclusiones alcanzadas mediante el estudio del conjunto de Santa Eulalia llevado a cabo por distintos equipos, con un planteamiento realizado desde la Arqueología de la Arquitectura, empleando un instrumento científico de validez contrastada mediante el cual hemos podido rescatar la microhistoria del edificio, lo que nos ha permitido acceder a su secuencia constructiva. Es decir, podemos hablar de una datación relativa de sus fases: una vez analizados los edificios que se han conservado en Bóveda, podemos ordenarlos secuencialmente.

Por otra parte, el trabajo con otros profesionales nos ha permitido aunar datos a la investigación histórica y, sobre todo, incorporar información desde otros campos disciplinares a cada una de las etapas diferenciadas. Este es, por ejemplo, el caso de la investigación realizada sobre las técnicas de los morteros y enlucidos de Santa Eulalia.

El estudio inicial del que parten los resultados que aquí presentamos se enmarcó en el proyecto de intervención realizado por el arquitecto César Portela entre los años 2006-2007 para la protección de los restos de la bóveda del piso superior, momento en el que la Dirección Xeral de Patrimonio Cultural de la Consellería de Cultura e Deporte de la Xunta de Galicia encarga al Laboratorio de

\footnotetext{
«El siglo VII frente al siglo VII: arquitectura» (Caballero et al., 2009).
} 
Patrimonio, Paleoambiente y Paisaje (IIT, USC), Unidad Asociada al CSIC, el levantamiento volumétrico y la lectura estratigráfica de alzados del edificio y a la empresa TOMOS Conservación-Restauración S.L., la consolidación de la bóveda alta, aunque finalmente, desde esta empresa, se opta por ampliar estos trabajos y realizar análisis de las patologías y morteros de todo el conjunto. Estos análisis, además, se plantearon sobre la base previa de los resultados del estudio estratigráfico. A partir de estos proyectos iniciales, hemos continuado un trabajo conjunto entre ambos equipos, al que posteriormente se ha sumado también un equipo de la Unidad de Geocronología del Instituto Universitario de Xeoloxía Isidro Parga Pondal (Universidad de A Coruña), que está llevando a cabo las dataciones por termoluminiscencia de material constructivo de las fases identificadas en el edificio.

\section{LAS ARQUITECTURAS DE SANTA EULALIA DE BÓVEDA}

Como ya habían apuntado algunos autores, no podemos hablar de una única Santa Eulalia, sino de varios edificios que partiendo de una forma específica, en palabras de Baker (1998: 70), se han ido superponiendo en el tiempo. Las transformaciones espaciales que ha sufrido Santa Eulalia han ido acompañadas, probablemente, de cambios funcionales que llevaron a sus usuarios a ir transformando poco a poco el edificio original en el conjunto monumental que hoy conocemos, incluyendo la iglesia parroquial de Santa Eulalia de Bóveda de Mera, que se construye a finales del siglo XVIII y que afectará a la conservación del edificio original, o las distintas actuaciones que a lo largo del siglo XX se han llevado a cabo en él con mayor o menor fortuna.

Con la intención de situar al lector haremos un breve resumen sobre las principales corrientes interpretativas del monumento ${ }^{2}$, que se mueven entre vincularlo a un origen cristiano o pagano, en cuanto a su funcionalidad, y romano o altomedieval en cuanto a su cronología. Las primeras interpretaciones sitúan al monumento como tardorromano, entre los siglos IV-V, y con un predominio cristiano, sería el caso de López-Martí (1934) quien encuentra en el monumento paralelos con el arte paleocristiano de las catacumbas romanas. A esta interpretación se sumará Martínez Morás (1927).

En 1935 Schlunk considera que el edificio tendría un origen romano, que fecha de forma provisional en el siglo IV, y una función funeraria relacionándolo con paralelos orientales del sur de Rusia y Siria. Incluye, inicialmente, la

\footnotetext{
${ }^{2}$ Se puede consultar en mayor detalle las distintas interpretaciones funcionales y cronológicas en Montenegro (2005 y 2008: 26-36) y un resumen de su cronología en Utrero (2006: 583-584).
}

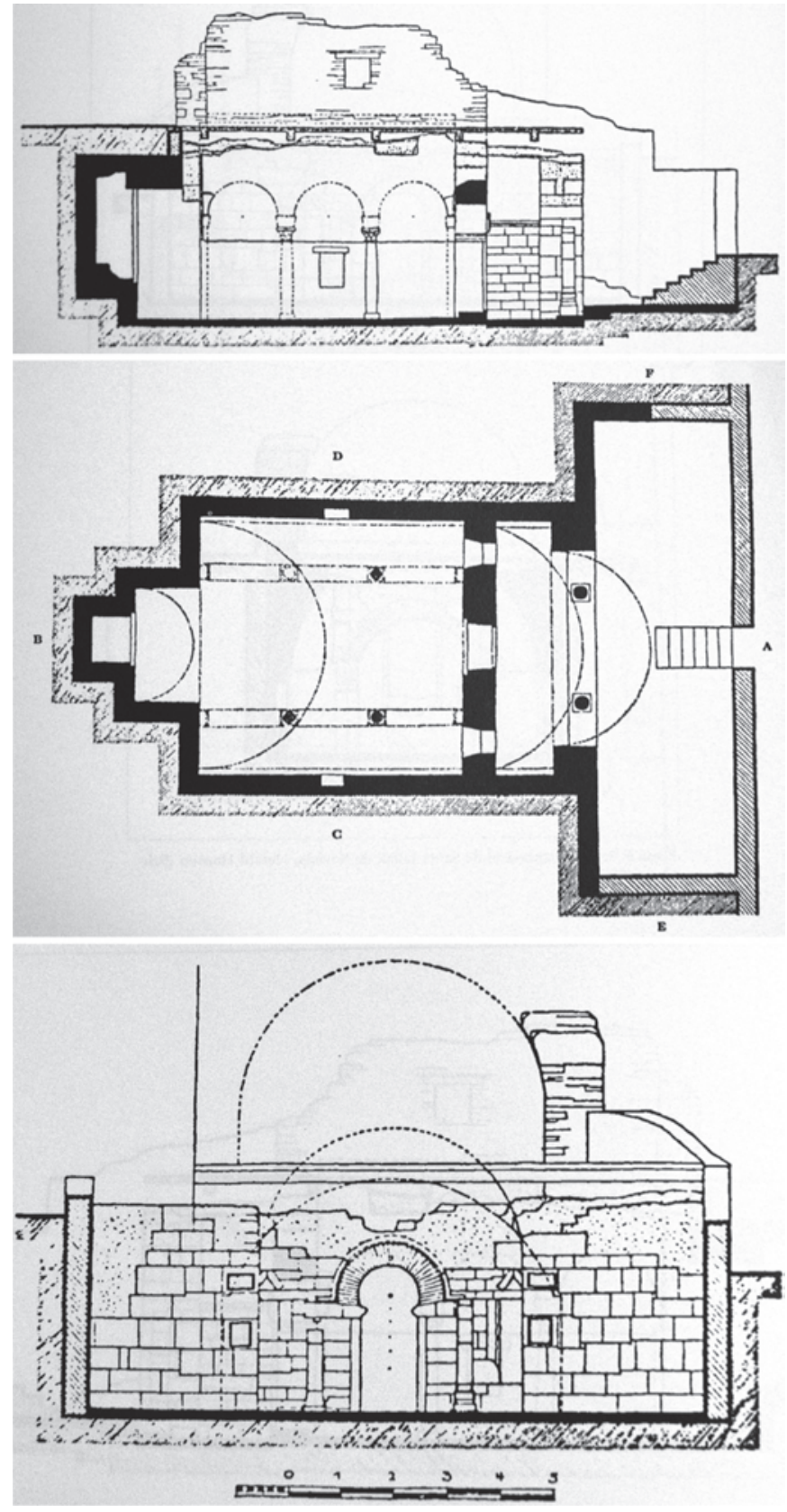

Fig. 3. Planimetrías de Santa Eulalia de Bóveda realizados por Herald Hanson (Schlunk, 1935): sección longitudinal, planta y alzado exterior

transformación del edificio en templo cristiano en el siglo IX, con la construcción de las arcadas, la reconstrucción de la bóveda y la decoración pictórica. Sin embargo, tras el descubrimiento por Chamoso de la piscina asume la interpretación de que se trata de un santuario medicinal, retrasando hasta época romana la reforma del interior del edificio (Montenegro, 2008: 35).

Ángel del Castillo (1932) lo identifica como un templo consagrado a las ninfas posiblemente del siglo IV. Gómez-Moreno (1949) considera que tanto la arquitectu- 

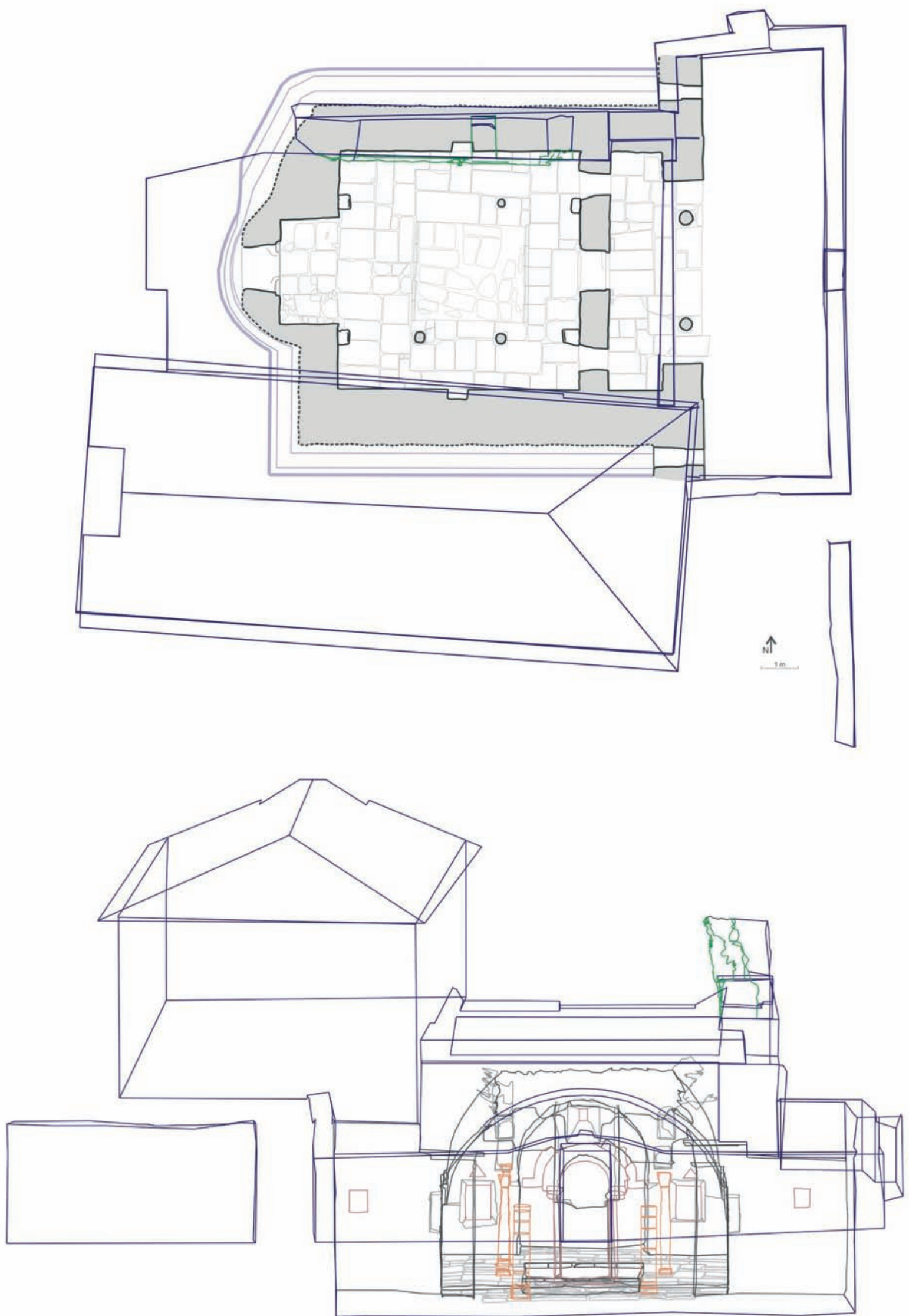

Fig. 4. Planta y vista tridimensional desde el E del conjunto monumental. En la planta se han marcado en verde los restos del piso superior. Como se puede apreciar, estos sobresalen del muro N de la planta baja del monumento. Dibujos realizados por P. Mañana-Borrazás y A. Rodríguez Paz 
ra como la decoración serían romanas con influencias del mundo oriental, pero retrae el origen a finales del siglo III, aunque apunta que las arcadas podrían no ser coetáneas al edificio original, sin aportar una fecha clara. En cuanto a la funcionalidad prioriza la interpretación como ninfeo (Montenegro, 2008: 29).

A partir del descubrimiento de la piscina, Chamoso Lamas (1952) vincula el origen del edificio a un ninfeo y la transformación del edificio a una fase visigoda con la introducción de las arcadas y la amortización de la piscina. Núñez (1978) considera que las características arquitectónicas de las fases iniciales del monumento se relacionan con la cultura castreña (Montenegro, 2008: 28) y que la transformación del edificio en un templo cristiano se produciría en el siglo VIII.

Acuña (1973) identifica también dos momentos constructivos, un edificio romano del siglo IV de una sola nave y una etapa cristiana con una planta basilical y la amortización de la piscina. Arias Vilas (1980) acepta también la existencia de dos fases, pero considera que la arquitectura y la decoración son coetáneas y las data en torno al siglo IV (Montenegro, 2008: 31).

Rodríguez Colmenero (1992 y 1993) relaciona el origen de Santa Eulalia con cultos de religiones orientales e identifica dos etapas constructivas en época pagana y otra en época cristiana, fechada esta última en la segunda mitad del siglo IV. Singul (1997 y 1998) considera que existirían también dos fases paganas (correspondientes a un edificio subterráneo de planta rectangular y a un edificio de dos plantas abovedadas, con nártex y ábside la inferior, respectivamente; Utrero, 2006: 584) y una cristiana (en la que se produce la división interna y el uso como baptisterio, amortizado posteriormente para uso basilical; Id.) fechada en la segunda mitad del siglo VI en la que se realizarían las pinturas.

Finalmente, Vidal Caeiro (2003 y 2006) propone la existencia de cinco fases constructivas, un edificio romano de aula rectangular; un edificio visigodo datado a finales del siglo V-finales del siglo VII, en el que se construye el ábside y una nueva fachada con el arco de herradura; un edificio perrománico del siglo VIII en el que se construye el piso superior, se retrae la fachada para construir un nuevo ábside abovedado y se construye la bóveda del aula; un edificio perrománico del siglo IX en el que se llevaría cabo la decoración pictórica, la arquería interior y el alfiz mozárabe de la entrada; en la última fase se incluirían las restauraciones contemporáneas (Utrero, 2006: 584).

En este apartado, trataremos de analizar los pormenores constructivos de los primeros edificios de Santa Eulalia, concretamente los correspondientes a las fases I, II y $\operatorname{III}^{3} \mathrm{y}$, basándonos en este análisis, recuperar la espacialidad de cada uno de ellos.

La metodología aplicada ha sido el análisis estratigráfico de alzados (tanto del edificio semienterrado como de los restos que se conservan del piso superior). Además se llevó a cabo el levantamiento planimétrico ${ }^{4}$ aplicando una herramienta topografía de alta definición mediante un Láser Escáner $3 \mathrm{D}^{5}$. Debemos indicar que, puesto que recientemente hemos publicado un artículo sobre Santa Eulalia de Bóveda $^{6}$ en el que se exponían los resultados de la lectura estratigráfica y del levantamiento planimétrico, obviaremos aquí todos aquellos aspectos relativos a la parte más metodológica, centrándonos en lo que desde la finalización de aquellos trabajos y desde que se realizó aquella publicación, pudimos avanzar una vez llevados a cabo los procesos interpretativos.

\section{Fase I}

De este momento únicamente se conservan los restos de un edificio semienterrado de planta cuadrangular absidiada y precedido por un nártex. Sin embargo, varios son los aspectos, que trataremos más abajo, que nos llevan a proponer la existencia ya desde este primer momento de dos pisos en el edificio, aunque posiblemente no conservemos nada de este segundo piso.

Este primer edificio se divide en dos espacios bien diferenciados, el aula absidiada y el nártex. En cuanto al aula, esta tiene una planta cuadrangular que mide entre 6,50 y 6,56 m de lado, tanto en el eje E-W como en el N$\mathrm{S}$; el ábside tiene una planta rectangular que mide $2,90 \mathrm{~m}$ en el eje N-S y 1,55 m en el eje E-W. Ambos espacios son coetáneos, ya que no se ha documentado un corte entre ellos ni cambios en el aparejo; lo mismo sucedería con respecto al nártex, a pesar de la diferencia de aparejo con el interior del aula.

Por su parte, el nártex tiene también una planta rectangular que mide $6,40 \mathrm{~m}$ en el eje N-S y $1,40 \mathrm{~m}$ en el

\footnotetext{
${ }^{3}$ Las fases IV y V corresponden a las intervenciones llevadas a cabo en épocas moderna y contemporánea, respectivamente, nos referiremos a ellas únicamente cuando sea relevante por su influencia en las fases anteriores. Para su descripción nos remitimos a Benavides y Blanco-Rotea (2008).

${ }^{4}$ Ficha Técnica: Dirección de la actuación: Rebeca Blanco-Rotea; Equipo técnico: Sonia García-Rodríguez, Patricia Mañana-Borrazás; Dibujos y reconstrucciones: Patricia Mañana-Borrazás y Anxo Rodríguez Paz; Croquis: Rebeca Blanco-Rotea y Sonia García Rodríguez; Fotografías: Rebeca Blanco-Rotea, Sonia García Rodríguez y Anxo Rodríguez Paz; Sistematización de la Información: Matilde Millán Lence.

${ }^{5}$ Tanto la metodología como los resultados de este levantamiento se pueden ver en Mañana et al. (2008).

${ }^{6}$ Benavides y Blanco-Rotea (2008).
} 


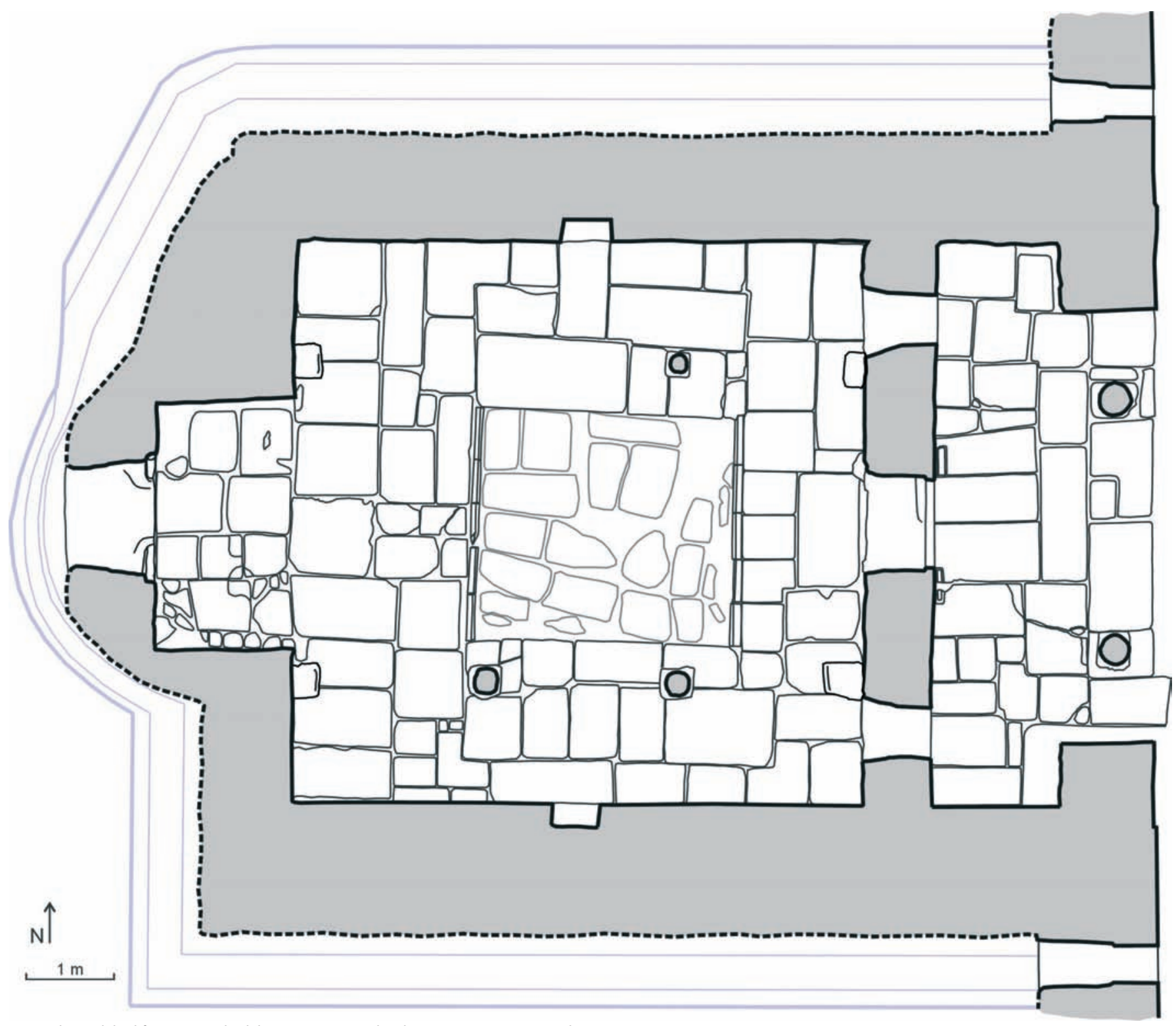

Fig. 5. Planta del edificio soterrado del monumento, realizada por P. Mañaná y A. Rodríguez Paz

eje E-W. Está precedido por grandes machones separados entre sí $5 \mathrm{~m}$ que miden de ancho $1,10 \mathrm{~m}$.

Para la construcción de este edificio se excavó el terreno, por lo que se encuentra, al menos parcialmente, enterrado ${ }^{7}$. Creemos que este hecho habría que vincularlo con la existencia en el aula de una piscina en la que se

${ }^{7}$ En un informe inédito de Rosa Gimeno (Portela y Gallego, 1990: 76-80) se mencionan varios aspectos interesantes a este respecto. En esta intervención se realizaron varios sondeos en el interior del edificio, el exterior de la entrada al mismo, el exterior de la parte alta del monumento y en sus alrededores. En estas dos últimas zonas, la arqueóloga documenta el xabre (suelo natural) a $3 \mathrm{~m}$ (concretamente a la altura del muro E de la actual iglesia parroquial) y $4 \mathrm{~m}$ (en la parte W de la iglesia, en este caso con un fuerte buzamiento hacia el $\mathrm{N}$ ) por encima del localizado en el monumento, dato que contribuye a afirmar que la zona en la que se emplaza el edificio de Santa Eulalia está excavada. Por otra parte, apunta también que «el xabre constituye una fuerte capa freática natural, y localizan dos canales con distinta orientación, ya que se estarían buscando los niveles freáticos, dato que ya apuntó Montenegro (2005: 96-97). En las distintas intervenciones realizadas en el subsuelo del edificio se documentan también canales situados por debajo de los muros perimetrales del aula y el nártex, dato recogido en los planos de González Trigo (Montenegro et al., 2008: 19, figura 15) y, más recientemente, en un croquis realizado por José López Fernández en el año 1992 (Id.: 93) durante la toma de datos en el edificio.

que quizás por posibles obras se halla [sic] alterado su discurrir natural, como lo pudimos comprobar ante la rápida subida del nivel de aguas en los diferentes sondeos.» (Id.: 80). Los análisis del agua indican que «se trata de agua potable tras ser clorada, poco mineralizada, con un pequeño contenido en sales, y con presencia de componentes tóxicos como el aluminio.» (Id.). 

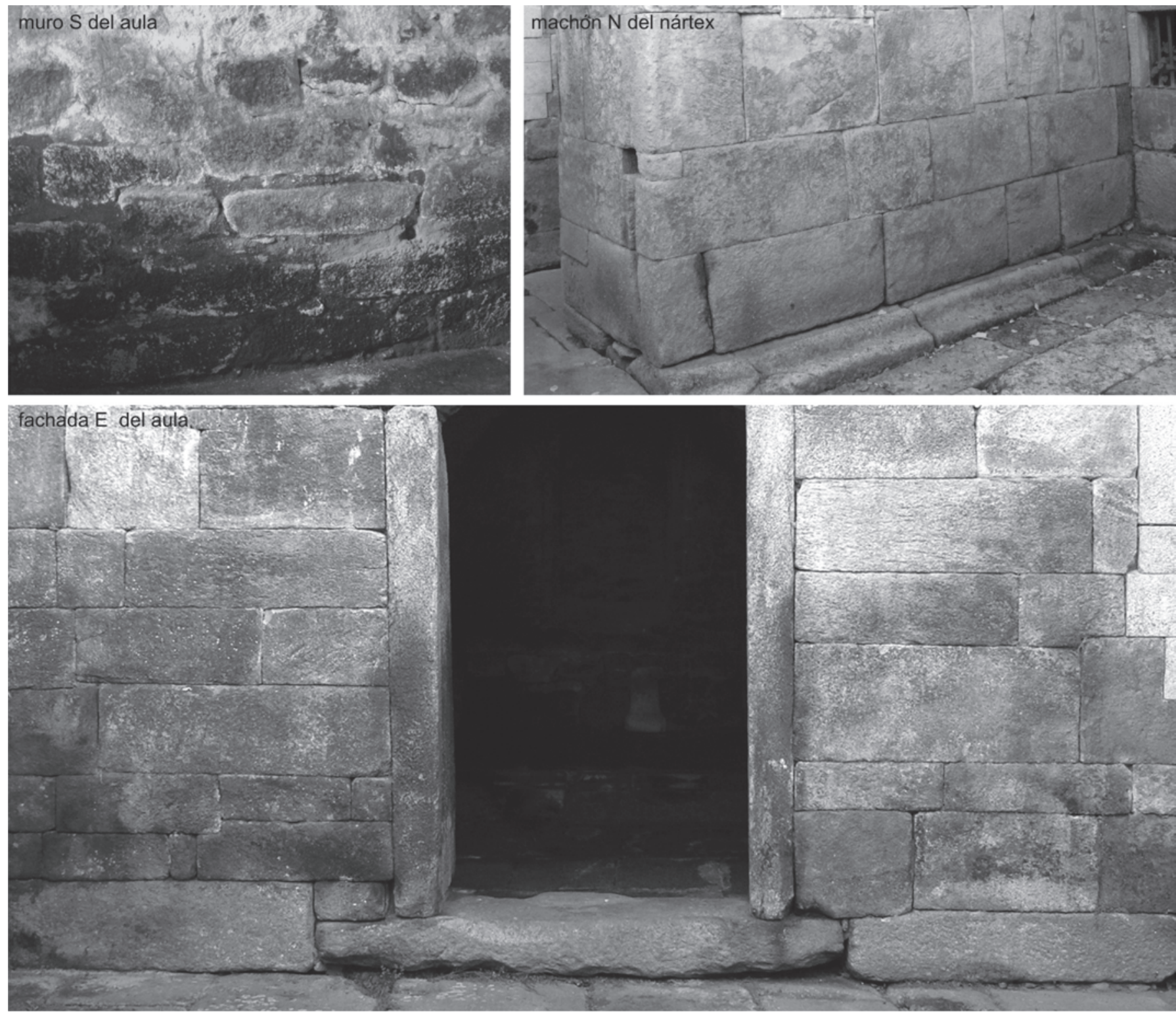

Fig. 6. Imágenes de los distintos aparejos de la fase I (muro interior y fachadas), en las que se aprecia también cómo los muros apoyan directamente sobre el enlosado

El muro perimetral del aula está realizado en un aparejo de mampostería irregular, de gran tamaño, en la que se emplean sillares, bloques y cantos de granito, reservándose las piezas más largas para las hiladas inferiores. Tiende a formar hiladas regulares, sobre todo en las zonas bajas del muro. Las juntas son muy anchas y se observan algunos ripios del mismo material, aunque en su mayor parte están revestidos de mortero.

Algunas piezas parecen reutilizadas, ya que presentan codos colocados en algunas ocasiones sin un concierto lógico y una de las piezas del muro $\mathrm{W}$ del testero tiene un perfil semicircular y parece una columna o el tambor de una columna.

Por lo que se ha podido apreciar en la cámara que circunda el edificio ${ }^{8}$, el muro está compuesto por una hoja exterior de mampostería (la que acabamos de describir) y un relleno de hormigón, con áridos de gran tamaño, un opus caementicium. Por lo tanto, funcionaría a modo de muro de contención del terreno excavado para la construcción del aula y el ábside.

${ }^{8}$ En la etapa en la que interviene González Trigo en Bóveda (1974-1983), con la intención de eliminar el alto grado de humedad existente en el interior que amenazaba las pinturas murales, se decide abrir una cámara bufa que circundará la planta baja del monumento por el N, W y S, así como construir una gran cubierta que proteja los restos del piso superior y permita abrir lucernarios para mejorar la ventilación y reducir la alta condensación del monumento (Montenegro, 2008: 18-19). Esta actuación, como apunta Montenegro, se lleva a cabo sin ningún tipo de control arqueológico. Una de sus consecuencias inmediatas es que se ha aislado el edificio de su contexto inmediato, cortando las relaciones estratigráficas que pudiera tener el yacimiento con otros elementos de su entorno. 


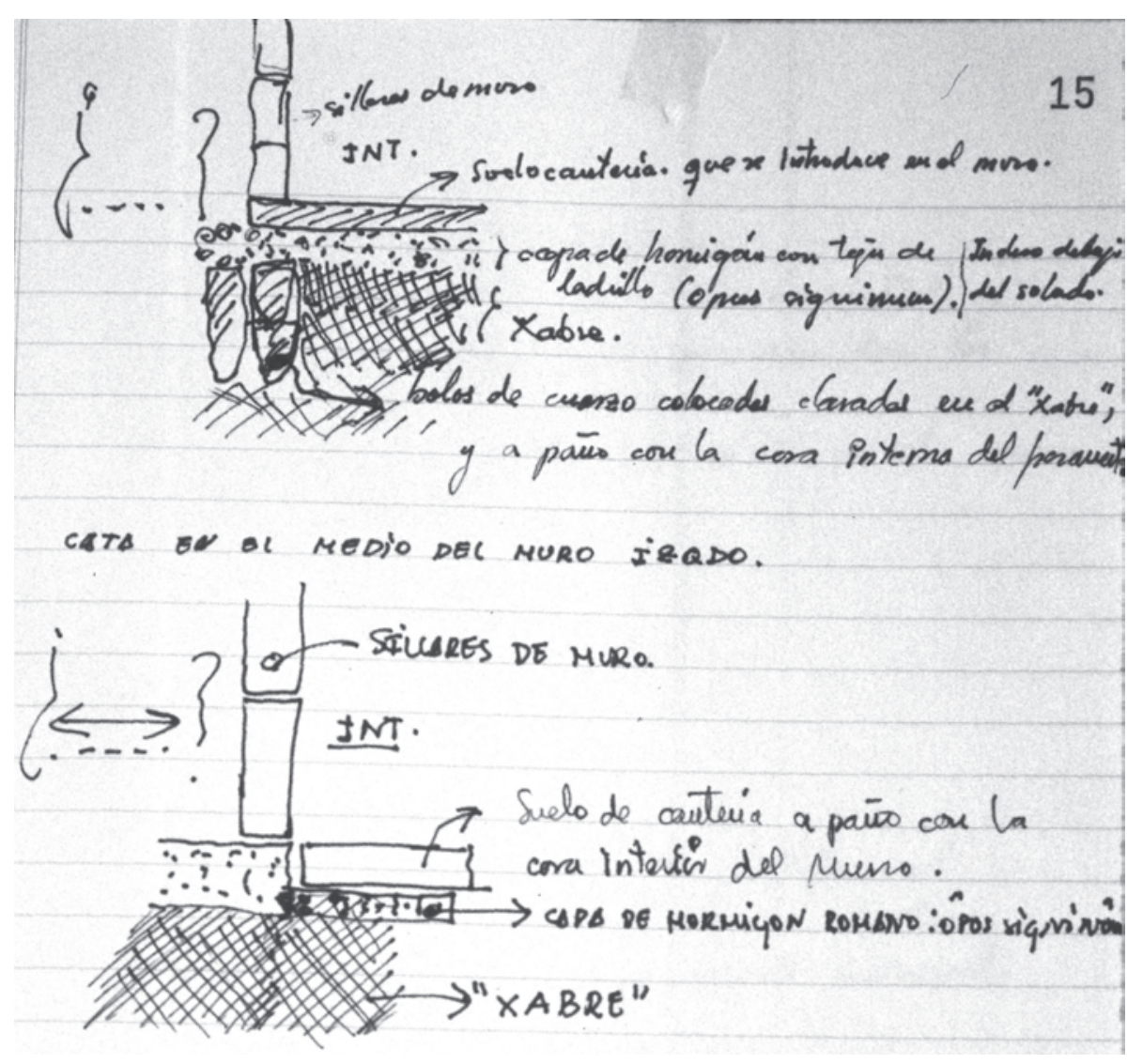

Fig. 7. Croquis de José López Fernández (en torno a 1989-1990) en el que se muestra un esquema de la cimentación de los muros del aula
Tanto la fachada del aula como los machones que cierran el nártex están realizados en un aparejo de sillería de granito de gran tamaño, sobre todo en los machones, donde el módulo de los sillares es mayor, en general, que en la fachada'. Los sillares se disponen a hueso siguiendo hiladas horizontales, sin regularidad en altura, y tienen las juntas muy finas. Muchos de los sillares presentan codos y las hiladas van disminuyendo de altura hacia los extremos del muro, sobre todo los parametos $\mathrm{N}$ y $\mathrm{S}$ del nártex y la fachada E del aula. Podríamos decir que la diferencia entre este aparejo y el de los interiores estriba en el tipo de material empleado y en la junta, pero no parecen corresponder a momentos cronológicos distintos, sino a su posición con respecto al edificio.

A pesar de la aparente irregularidad de estos muros (el interior y las fachadas) que podrían llevarnos a pensar en la mala calidad de las fábricas, creemos interesante traer a colación la siguiente cita de Utrero: «Las irregularidades y sinuosidades de las hiladas [...] contribuyen a armar los muros. Estos caracteres contradicen la estética de los

\footnotetext{
${ }^{9}$ En el caso de los machones la altura de las hiladas oscila entre los 32 y los 56 $\mathrm{cm}$, siendo la media de $44,5 \mathrm{~cm}$, y en la fachada oscilan entre 15 y $54 \mathrm{~cm}$, siendo la media de $40 \mathrm{~cm}$.
}

paramentos y pueden conducir a una interpretación errónea sobre la mala calidad de las fábricas que no se preocupan de una regularidad o no son formalmente homogéneas.» (id., 2006: 58).

En cuanto a la cimentación, hemos de decir que los muros carecen de zanjas para su cimentación. Estos se asientan directamente sobre el enlosado (ver figura 6). Cabría pensar que la zanja de cimentación para los muros del aula y el ábside, si es que existió, tendría relación con la excavación que se hace para la construcción del edificio; es decir, estaría relacionada con el muro de hormigón que constituye el alma del muro perimetral, pero, desgraciadamente, como comentamos en la nota 8, esta fue excavada por González Trigo para la construcción de la cámara bufa y, por lo tanto, no podemos saber qué tipo de zanja se construye para cimentar los muros perimetrales del edificio. Nuevamente, gracias a uno de los croquis realizados por José López Fernández (ver figura 7), quien estuvo presente en la intervención arqueológica realizada por Rosa Gimeno (Montenegro et al., 2008: 20-21), podemos rastrear las características de esta cimentación que, según su croquis, se compone en un caso desde la base de granito descompuesto (xabre), bolos de cuarzo hincados bajo el muro, una capa de opus signinum, el enlosado y el muro, 

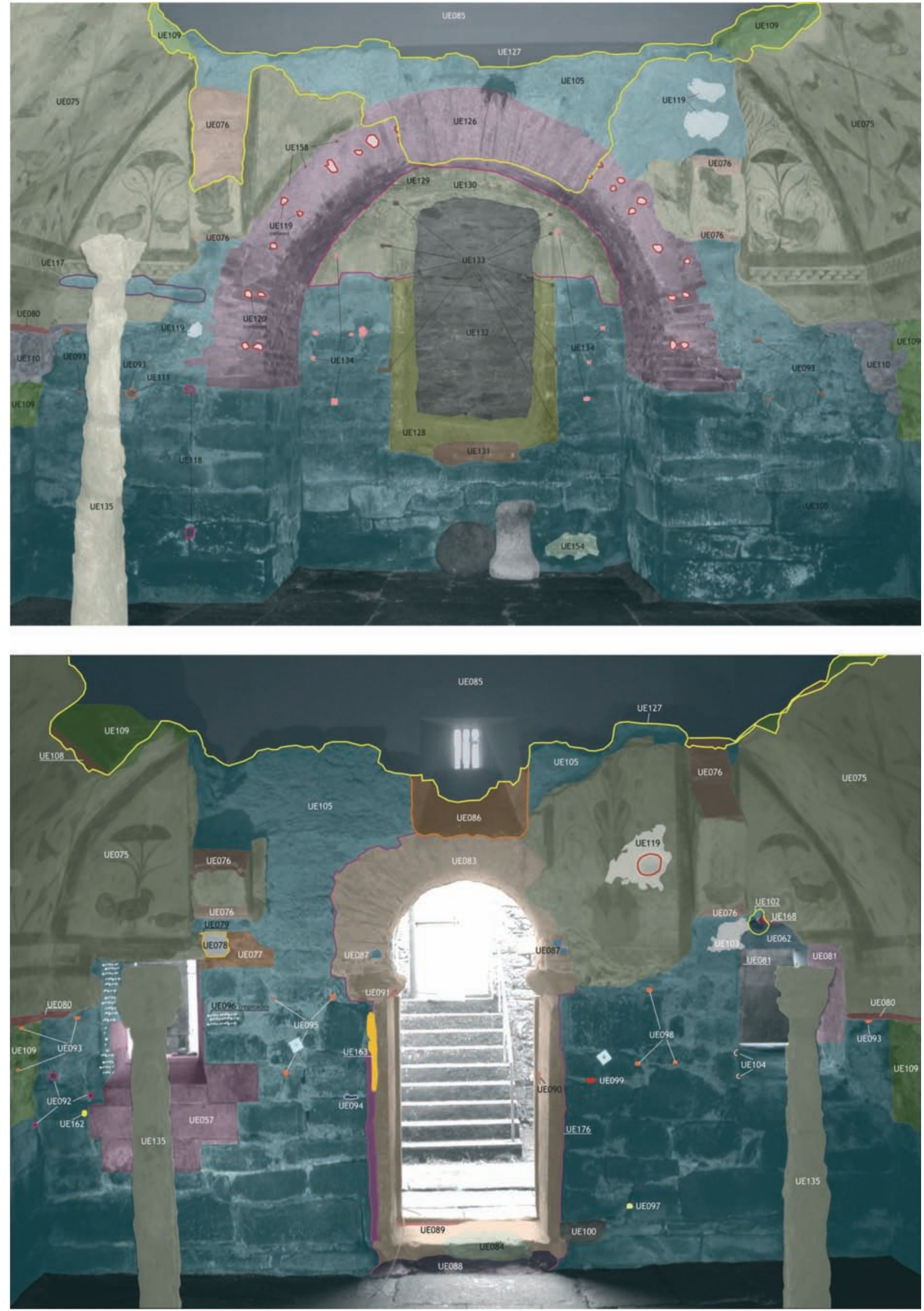

Fig. 8. Lecturas de los paramentos W (imagen superior) y E (imagen inferior) del aula 


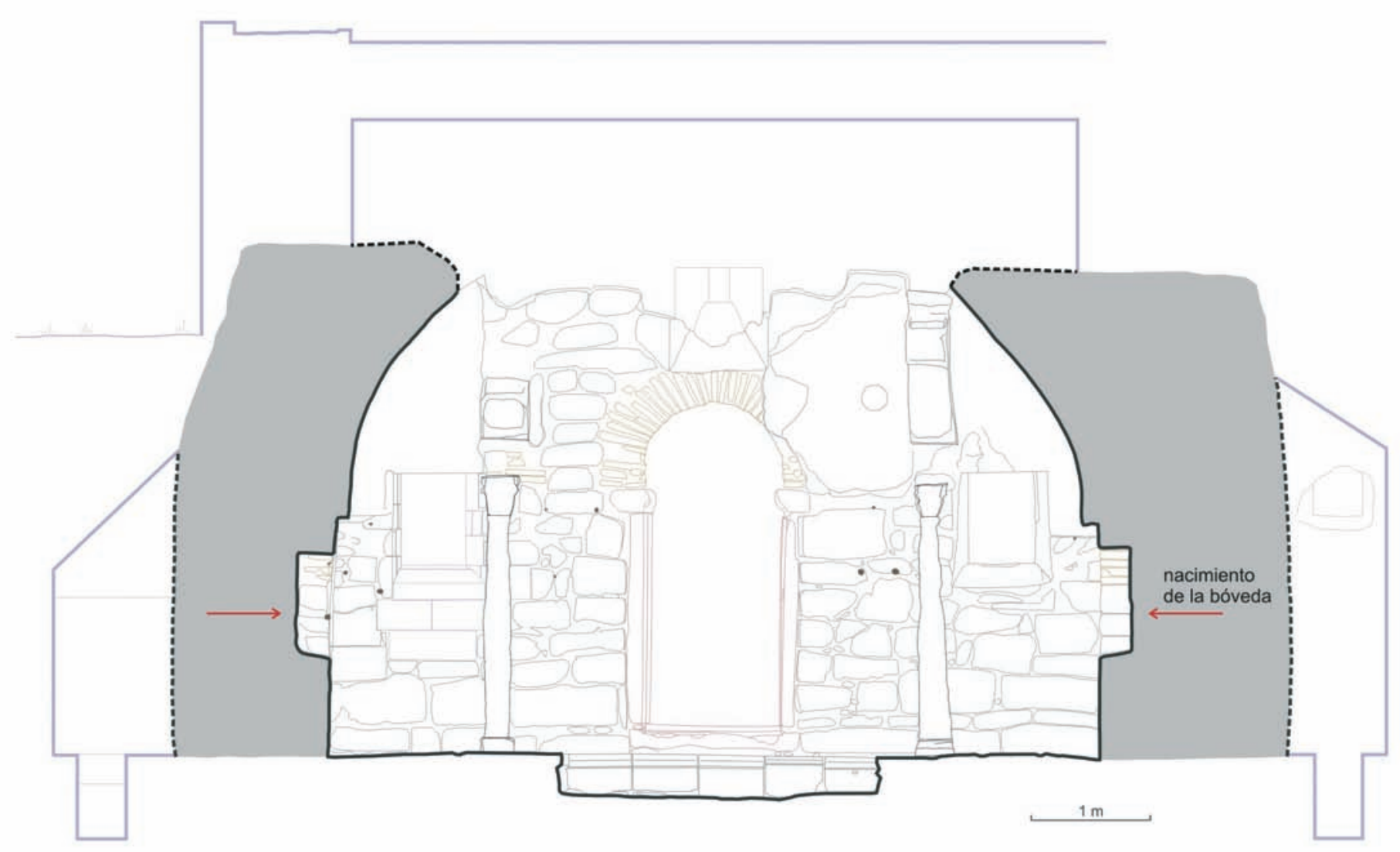

Fig. 9. Sección N-S del aula. Las flechas rojas indican la altura a la que nace la bóveda, Id fig. 5

mientras que en otro caso el muro se apoya directamente sobre el opus signinum y las losas del suelo se adosan a la hoja exterior del paramento, pero en ambos carecen de zanja de cimentación. Según apunta Utrero las cimentaciones no se ajustan a un tipo preestablecido siendo las características del terreno y el tipo de estructura las que marcan sus condicionantes, por ejemplo, en el caso de construirse sobre el geológico de piedra se prescinde de zanjas o zócalos y los cimientos son mínimos o inexistentes. Finalmente, apunta algunos ejemplos que revelan que las estructuras abovedadas no van necesariamente asociadas a cimentaciones profundas ya que la seguridad del asiento se busca en la superficie de apoyo; es decir, en el grosor, no en la profundidad (Utrero, 2006: 53-54). Este último podría ser el caso de Bóveda.

Tanto el aula como el nártex están abovedados; sin embargo, llevamos la bóveda del nártex a una fase posterior. En el caso del aula se conservan únicamente los tramos de la bóveda que corresponderían a las naves laterales ${ }^{10}$, ya que a la altura de los restos de los enjarjes de la arcada que dividía el aula la bóveda se ha fracturado de $\mathrm{E}$ a W. Este hecho nos permite comprobar el sistema cons-

${ }^{10}$ Esta división espacial se llevaría a cabo en una segunda fase. tructivo de este elemento, lo cual no sería posible de otra manera, ya que se encuentra cubierto por pinturas. Se trata de una bóveda de cañón generada por un arco de medio punto peraltado, que arranca a una altura localizada entre 1,11 y $1,18 \mathrm{~m}$ del suelo ${ }^{11}$. La bóveda está realizada con plementería de hormigón y seis arcos fajones de ladrillo incluidos en la rosca de $0,40 \mathrm{~m}$ de anchura y dispuestos a intervalos regulares de $0,60 \mathrm{~m}$. Los ladrillos tienen una anchura que oscila entre los 5 y los $7 \mathrm{~cm}$ y un largo de 20 $\mathrm{cm}$. Están asentados con una capa de mortero que emplea como aglomerante arcilla y cal (esta en menores proporciones que el resto de los morteros analizados; ver la descriptiva del mortero 1a en la Tabla 1). Llama la atención la inclinación que tienen algunos de estos arcos desde su nacimiento en sentido E-W, lo cual se puede apreciar en los dos primeros arcos $\mathrm{W}$ del alzado $\mathrm{N}$.

El ábside está también cubierto por una bóveda construida en ese caso íntegramente en ladrillo. La rosca del arco de ingreso al ábside es de ligerísima herradura, que

${ }^{11} \mathrm{El}$ arranque de los arcos fajones de la bóveda empieza a mayor altura, entre 1,40 y $1,50 \mathrm{~m}$ del suelo, pero entre el muro del aula descrito arriba y el arranque de los fajones se dispone una zanja de opus caementicium que podría estar regularizando la parte superior del muro y que hemos incluido dentro de la estructura de la bóveda por ser del mismo material que esta. 

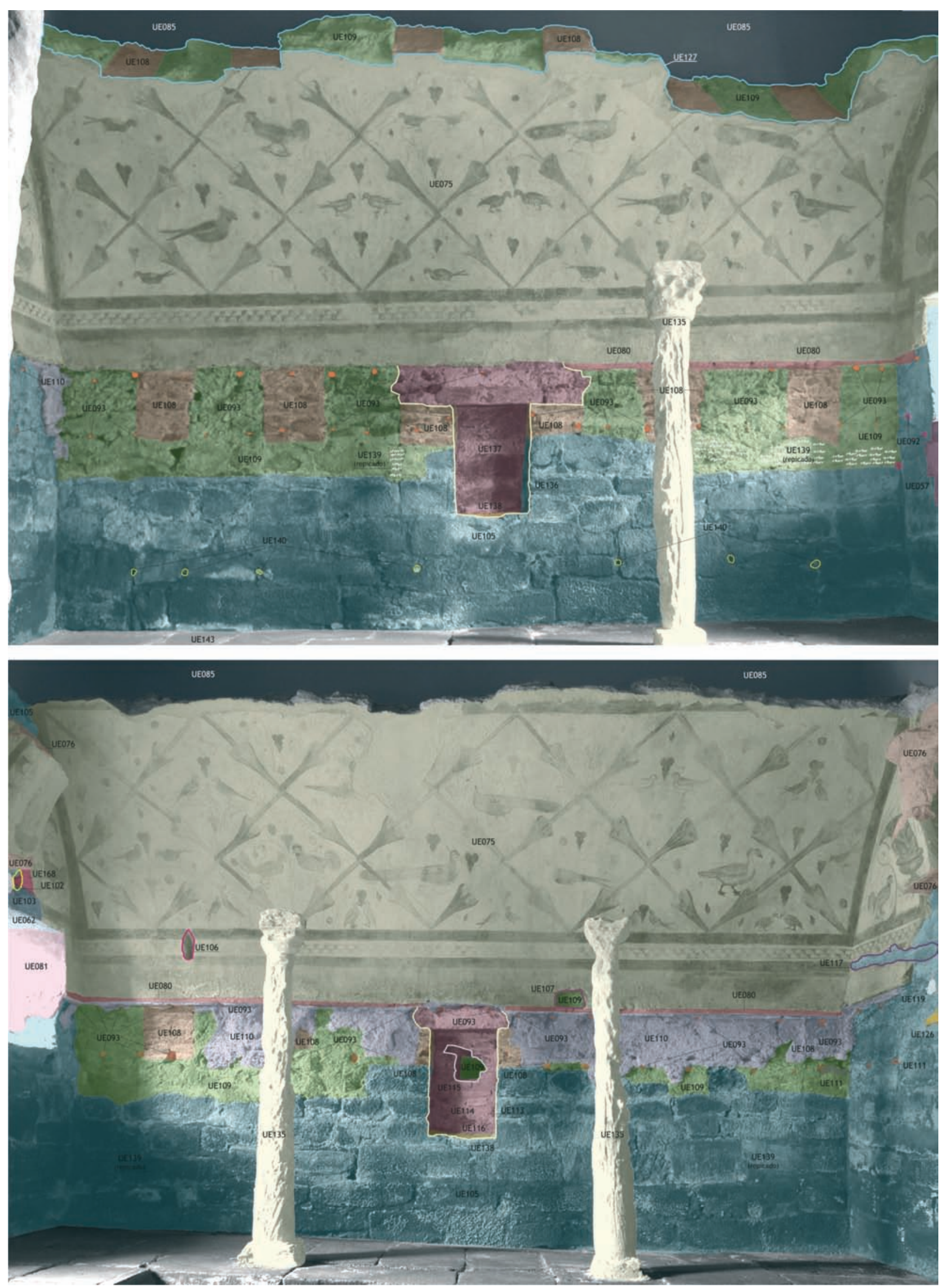

Fig. 10. Lecturas de los alzados $\mathrm{N}$ (imagen superior) y $\mathrm{S}$ (imagen inferior) del aula 


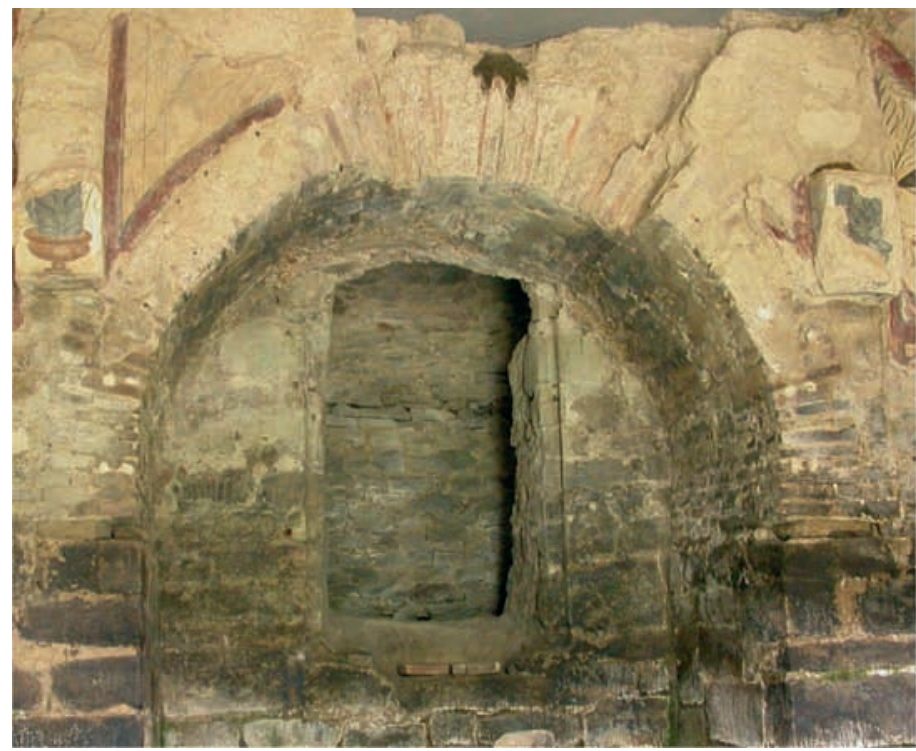

Fig. 11. Fotografías de la bóveda del ábside

se forma porque desde el salmer los ladrillos van retranqueando ligeramente. Esta forma del arco prácticamente no se aprecia y semeja un arco de medio punto peraltado.

En las partes bajas de la rosca sobresale el ladrillo del extradós del arco, en una hilada en el lado $S$ y cuatro hiladas en el lado N. A partir de ahí el extradós del arco sigue la misma curvatura. En la zona de la clave se emplea una alternancia de un ladrillo grueso (de entre $5 \mathrm{~cm}$ y 5,50 $\mathrm{cm}$ ) y uno más estrecho (de entre $3 \mathrm{~cm}$ y $3,50 \mathrm{~cm}$ ), que alterna hasta cuatro veces y a los lados de esta alternancia se disponen tres ladrillos estrechos. A partir de estos y hasta la imposta sobre la que descansa el arco son ladrillos gruesos.

Los ladrillos no siempre son enteros, sino que hay algunos cortados para alcanzar las medidas tanto del arco exterior como de la bóveda. La rosca descarga sobre sendas impostas de mármol, material actualmente muy desgastado.

Con respecto a las medidas cabe destacar algunos aspectos que aportan información sobre la forma de construir el arco. Las medidas de la rosca del arco son: en el lado $S$ el salmer mide $0,45 \mathrm{~m}$ y la primera dovela $0,60 \mathrm{~m}$; en el lado $\mathrm{N}$ el salmer mide $0,60 \mathrm{~m}$ y la primera dovela $0,46 \mathrm{~m}$ (en este caso hay que destacar la alternancia de medidas entre el lado $S$ y el N). A partir del salmer y hasta la tercera dovela, tanto en el lado $\mathrm{N}$ como en el $\mathrm{S}$, van retranqueando ligeramente, como ya se comentó. A partir de la cuarta dovela ya comienzan a sobresalir, dando lugar a la curvatura del arco.

Las medidas de la rosca son en los hombros entre 0,40 m y $0,41 \mathrm{~m}$, en los riñones $0,50 \mathrm{~m}$ y en la clave $0,59 \mathrm{~m}$. Una vez que el arco se unifica a partir de las primeras

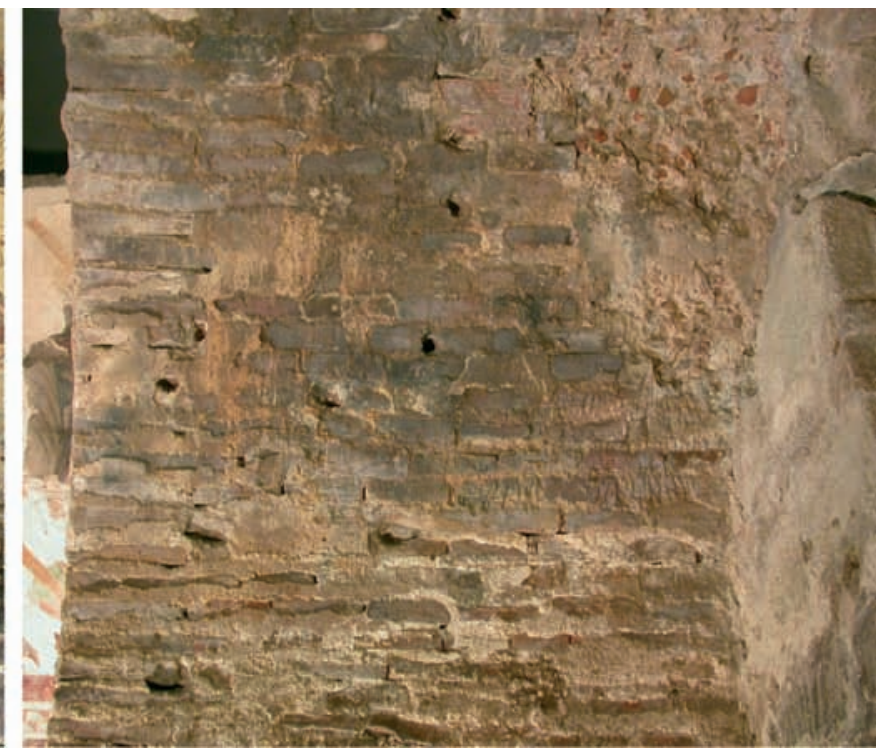

dovelas, como se comentaba antes, las medidas van aumentando desde los hombros hacia la clave; entre los hombros y los riñones se aumentan $10 \mathrm{~cm}$ y entre los hombros y la clave entre 9 y $10 \mathrm{~cm}$. La forma de disponer las dovelas de la rosca, asentadas las primeras horizontalmente respecto al muro y formando con el mortero la curvatura del arco, es semejante a la empleada en los arcos fajones.

Con respecto a la bóveda, el intradós del lado $S$ mide $1,56 \mathrm{~m}$ y el del lado $\mathrm{N} 1,58 \mathrm{~m}$. La luz es de $2,90 \mathrm{~m}$ y la flecha de $1,70 \mathrm{~m}$.

En el intradós de la bóveda, tanto en el lado $\mathrm{N}$ como en el S, entre los ladrillos se documenta hacia la zona de los hombros una hilada realizada con mampuestos de granito; el resto (al menos en lo que se aprecia entre el mortero) está realizado con ladrillo. El intradós de la bóveda iba revestido de mortero y se han registrado abundantes agujeros que la cortan (la mayoría de ellos circulares y que ponemos en relación con los agujeros documentados en los alzados del aula que comentaremos en la fase II).

En su lado W la bóveda está cortada para abrir el hueco de una puerta rematada en un arco escarzano que hemos llevado a la fase IV.

Sobre la mampostería de los alzados $\mathrm{N}$ y $\mathrm{S}$ del ábside, a la altura del salmer y la primera dovela de la rosca del arco, se disponen en la bóveda unas hiladas de regularización hechas con fragmentos de ladrillos. Es más evidente en el lado $\mathrm{N}$ de la bóveda, ya que allí la última hilada de este alzado de mampostería es más irregular que en el $S$.

El aula contaba en esta fase con un único vano de acceso situado en la fachada E. Formalmente sería distinto 

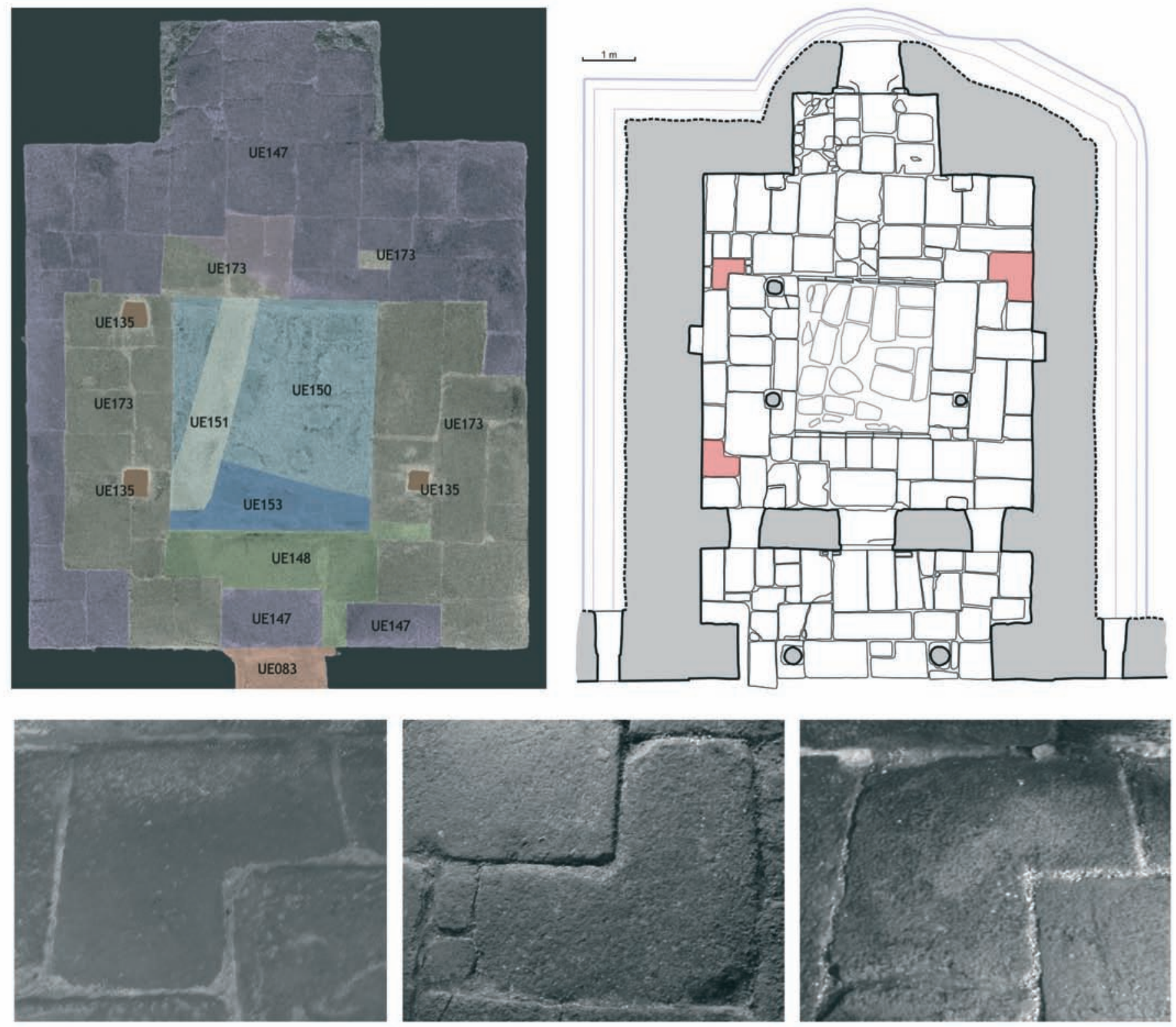

pieza SE

pieza SW

pieza NW

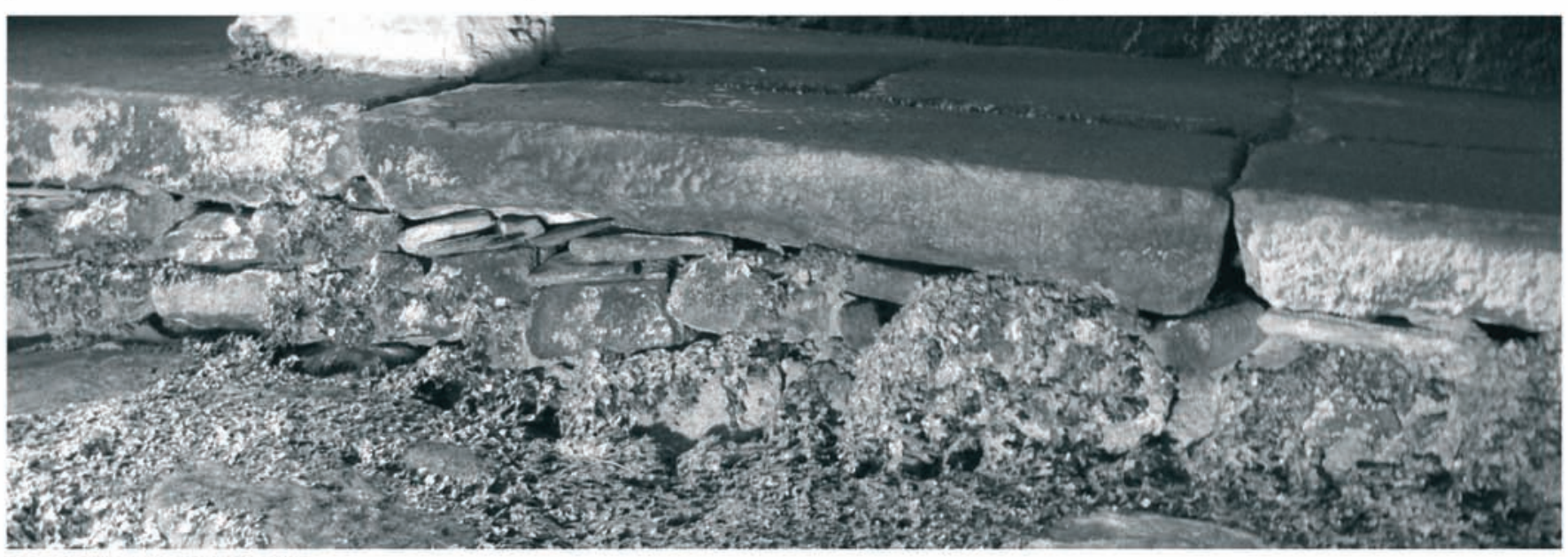

paramento sur de la piscina

Fig. 12. Distintos aspectos del enlosado y la piscina del aula. En la planta se han marcado en rojo las piezas que, según la hipótesis barajada, enmarcarían la piscina de la fase I 
al actual, ya que la actual puerta corresponde a la siguiente fase, como lo demuestra el corte documentado en los sillares de la fachada y del alzado E interior que comentaremos en el siguiente apartado. Desconocemos cómo sería la puerta original. Para la reconstrucción hipotética de la fase I hemos decido emplear el único sistema original de los vanos de esta fase, las ventanas, que son adinteladas. Las dos ventanas, situadas a ambos lados de la puerta, tienen además un arco de descarga en mitra sobre ellas, ambos realizados con el muro.

Otro de los elementos característicos de la fase I, con toda probabilidad relacionado con la función originaria del monumento, es la piscina que se localiza en el aula en la que se pueden apreciar las tapas de dos canalizaciones en su base, una dispuesta en sentido NNE-SSW y la otra en sentido W-N-W y E-S-E. Una vez estudiado el edificio, creemos que la piscina original sería de mayores dimensiones que la que actualmente se puede observar en el monumento, acortada o colmatada con la división espacial realizada en la fase II, con motivo de la disposición de las arcadas. La diferenciación del espacio que originalmente ocuparía la piscina resulta bastante problemática, ya que el enlosado de aula y ábside ha sido levantado en varias ocasiones, en relación con las distintas intervenciones que se han llevado a cabo en el subsuelo, entre ellas la eliminación del enlosado de mármol que cubría la piscina, una vez descubierta por Chamoso Lamas (1952). Para su diferenciación, nos hemos basado en el análisis visual de los materiales, ya que se observaban materiales de distinto tipo (de piedra, de acabados, de morteros), en las planimetrías anteriores y en las fotografías realizadas en intervenciones anteriores.

Si observamos la planta del aula (figuras 5 y 12), se puede apreciar cómo se conservan tres piezas cortadas en ángulo recto ${ }^{12}$, las únicas de estas características que existen en el suelo (se han marcado en color rojo en la figura 12). La hipótesis que barajamos es que estas piezas formarían parte de las esquinas de la piscina original, que se habría reducido en el momento en que se disponen los elementos sustentantes de las arcadas que dividen el aula. Las piezas NW y SW se encuentran en línea entre sí y con el lado W de la actual piscina. La SW está a su vez en línea con otra pieza situada en la esquina SE del aula. Esta última, sin

\footnotetext{
${ }^{12}$ Este dato ya lo apuntó Montenegro (2005: 46, figura 10), marcando cuatro piezas en ángulo recto sobre el primer plano de detalle del pavimento realizado por Chamoso Lamas. Sin embargo, la cuarta pieza, la NE, actualmente no se localiza en el pavimento. Por otra parte, Montenegro indica que estas piezas encuadran un área en relación a la piscina, pero no hace mención a la posibilidad de que esta hubiera sido de mayores dimensiones.
}

embargo, no está en línea con el alzado E de la piscina, tal vez porque el límite $\mathrm{E}$ de la actual piscina no se corresponda con el original. Según se aprecia en las fotografías de Chamoso Lamas (Id.: 245, Lámina VIII), el límite E de la piscina localizada bajo las losetas de mármol se encontraba más próximo a la fachada $\mathrm{E}$ del aula que el actual, acortándose durante la reconstrucción llevada a cabo en la intervención de Menéndez Pidal y Pons Sorolla, entre 1953 y 1960 en la que además, los lados E y W de la piscina se forran con molduras de granito imitando una pieza localizada en el interior de la misma. Se habría perdido la pieza que suponemos se localizaría en la zona NE que aparecía dibujada en el plano de Chamoso Lamas (ver nota 12). Si trazamos una línea recta desde la pieza NW hacia el $\mathrm{E}$ y desde la SE hacia el N, el punto de encuentro entre ambas nos daría el límite de lo que suponemos sería la piscina original. A todo ello debemos sumar el acabado que tienen los muros laterales $\mathrm{N}$ y $\mathrm{S}$ de la piscina, con diferente tratamiento a los otros dos que, por otra parte, han sido reconstruidos, como comentamos, por Menéndez Pidal y Pons Sorolla. En estos alzados se aprecia bajo el enlosado un relleno de mampostería de pequeño tamaño dispuesta a hueso (se puede observar en la imagen inferior de la figura 12), un tratamiento poco cuidado para el cierre de una piscina, a no ser que estuviera revestido, hecho que no se documentó durante la intervención de Chamoso Lamas.

Finalmente, nos queda por comentar en la fase I la cuestión que apuntamos más arriba sobre la posibilidad de la existencia de dos pisos desde el primer momento en Santa Eulalia ${ }^{13}$. La primera imagen que se tiene del monumento, una vez que hemos bajado las escaleras, son dos grandes machones, de $1,10 \mathrm{~m}$ de ancho el $\mathrm{N}$ y $1,14 \mathrm{~m}$ el $\mathrm{S}$, que cierran un espacio de $1,40 \mathrm{~m}$ de ancho, el que corresponde al nártex. Llama la atención la relación existente entre el espacio que se debe cerrar y la medida de los machones. Por otra parte, estos están realizados, como ya se comentó, con grandes sillares de granito, de hasta $56 \mathrm{~cm}$ de alto y $1 \mathrm{~m}$ de largo (las piezas dispuestas a tizón miden el ancho del muro). Si tenemos en cuenta que el edificio está semienterrado y que los muros perimetrales transmiten sus empujes horizontalmente (al estar abovedado) hacia el terreno excavado, estos grandes machones no pueden ponerse en relación con la estructura inferior. De ahí que consideremos que funcionalmente tienen sentido si desde el primer momento se proyecta la construcción de

\footnotetext{
${ }^{13}$ Queremos agradecer al arquitecto Antonio de Vega Rodríguez y al restaurador y arqueólogo Miguel Ángel López Marcos las discusiones mantenidas a este respecto.
} 


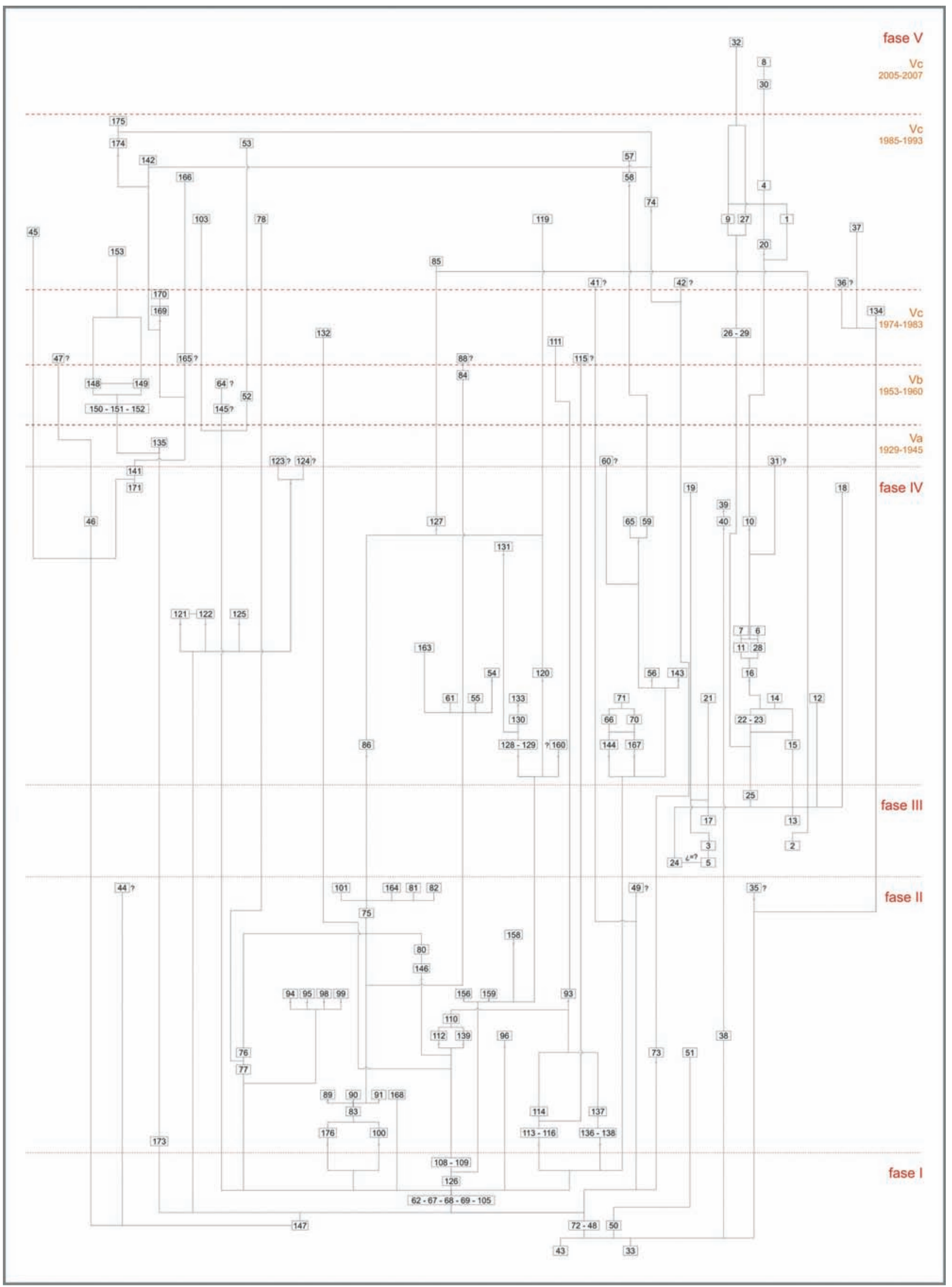

Fig. 13. Diagrama de UE de Santa Eulalia de Bóveda 


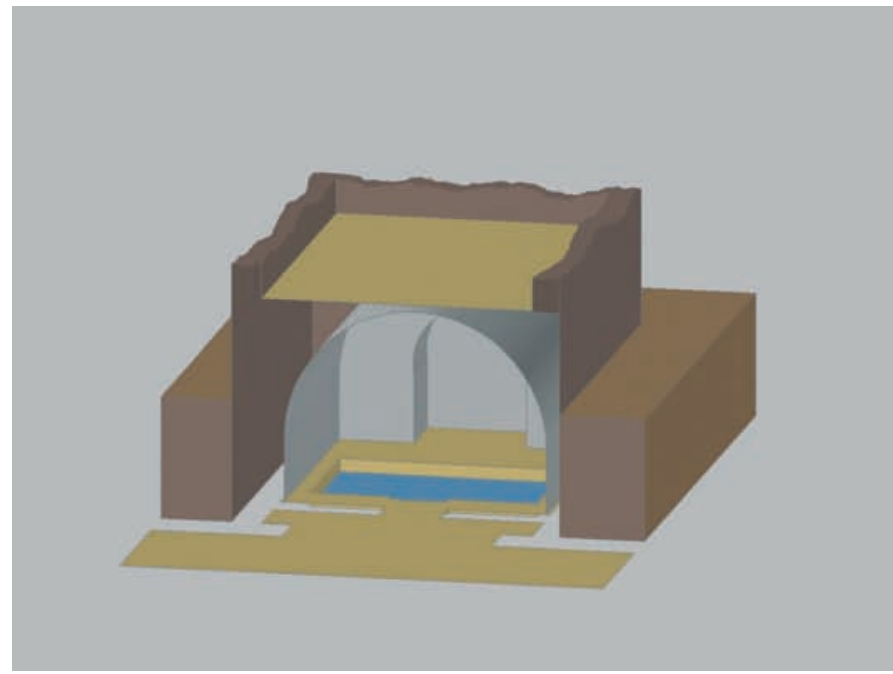

Fig. 14 Reconstrucción hipotética de la fases I y III realizada por A. Rodríguez Paz

un edificio con dos pisos que además, por el $\mathrm{E}$, se adelantaría hasta el límite de los machones. No podemos saber, sin embargo, cuál sería el sistema de cubierta empleado en ese segundo piso ya que no creemos, como se comentará, que el muro $\mathrm{N}$ que se conserva corresponda a esta primera fase por las diferencias constructivas que guarda con la bóveda del aula. Lo mismo sucedería con la cubierta del nártex, ya que la actual bóveda la hemos llevado a la fase IV, o con el tratamiento de la fachada, es decir, el remate de los machones que, por sus dimensiones parece que estarían soportando un gran arco, pero como decimos no tenemos los suficientes datos como para poder afirmar estas hipótesis. Es por ello que en la reconstrucción nos hemos limitado a insinuar los muros del segundo piso.

\section{Fase II}

La fase II de Santa Eulalia se centra en la transformación del espacio inferior, ya que los restos del segundo piso se corresponderían a un tercer momento constructivo. Aunque, como ya apuntábamos en Benavides y Blanco-Rotea (2008), teníamos algunas dudas con respecto a la fase III y su coetaneidad o no con la fase $\mathrm{II}^{14}$, los resultados preliminares de las analíticas realizadas hasta el momento parecen confirmar la diferencia entre los materiales constructivos analizados en la planta inferior y la superior ${ }^{15}$, apoyando la hipótesis sobre su adscripción a momentos distintos.

${ }^{14}$ Comentábamos en ese artículo la imposibilidad de comprobar la relación estratigráfica existente entre los elementos de ambas fases ya que esta había quedado oculta bajo la estructura de hormigón que actualmente cubre la planta inferior (Benavides y Blanco-Rotea, 2008: 56-57).

${ }^{15}$ Ver en este mismo texto el apartado Propuesta metodológica y limitaciones para la datación absoluta del monumento y, dentro de este, ver Resultados preliminares.

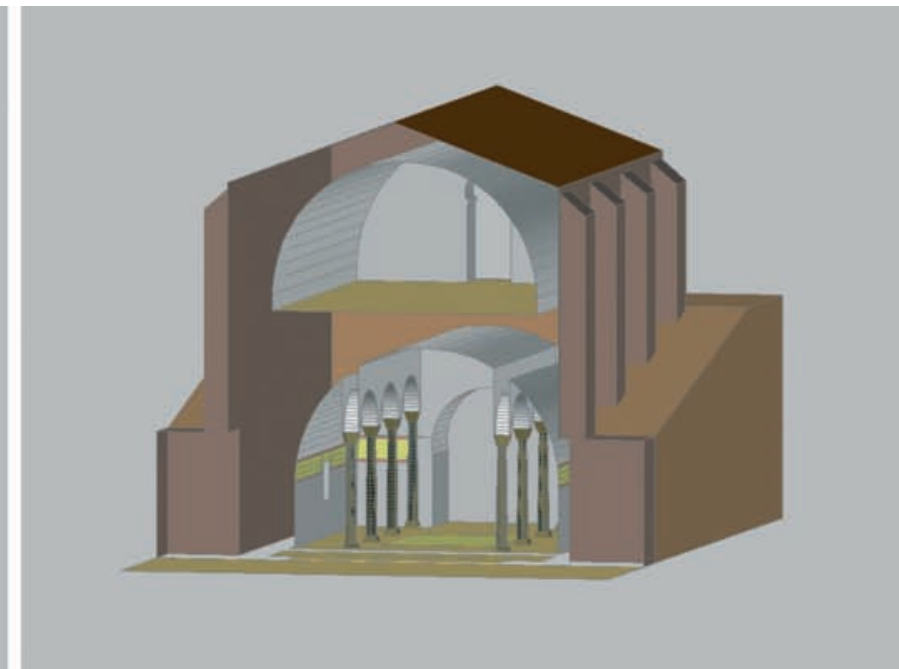

Estas reformas corresponden a cuatro aspectos, la división del aula en tres naves, la decoración del interior del aula con pinturas y placas, posiblemente decoradas ${ }^{16}$, la reforma de la puerta de entrada al monumento y la posible modificación de la fachada principal.

La división del aula en tres naves se efectúa mediante la construcción de dos arquerías dispuestas en sentido EW, cada arquería tendría tres arcos de medio punto ${ }^{17}$ construidos en ladrillo, piedra y mortero, aunque solamente se conservan los arranques de estos en los testeros del edificio. Para su construcción se practican varios cortes en ambos muros, en los que se embuten mampuestos de granito de manera intermitente, entre los cuales se disponen las piezas de ladrillo que se adosan al muro. Un dato que cabe resaltar en este caso, es la diferencia con respecto a los arcos fajones en la disposición de los ladrillos. Como ya comentamos, en los fajones cada ladrillo se separa del siguiente con una capa de mortero que mantiene el grosor en todo el ancho del ladrillo. Por el contrario, en los enjarjes, los ladrillos en el intradós presentan una junta más fina que se va engordando hacia el extradós, creando la curvatura con el mortero ${ }^{18}$ (este mismo sistema se documenta en los restos de la bóveda del piso superior, aunque

\footnotetext{
${ }^{16}$ Ambos aspectos serán tratados en detalle en el apartado correspondiente.

${ }^{17}$ Tanto la hipótesis de que cada arquería contaría con tres arcos como la forma de estos se basa en la reconstrucción de la curvatura que se conserva en los enjarjes realizada a partir de la topografía de alta definición que se ha llevado a cabo en el edificio.

${ }^{18}$ Creemos importante resaltar la función de los morteros en Santa Eulalia, que han tenido un papel importante a la hora de decidir qué tipo de analíticas llevar a cabo en el edificio. Como apunta Utrero (2006: 50) la verdadera función del mortero «es ayudar a transmitir la carga de compresión a través de toda superficie de contacto a unión, es decir, la junta».
} 

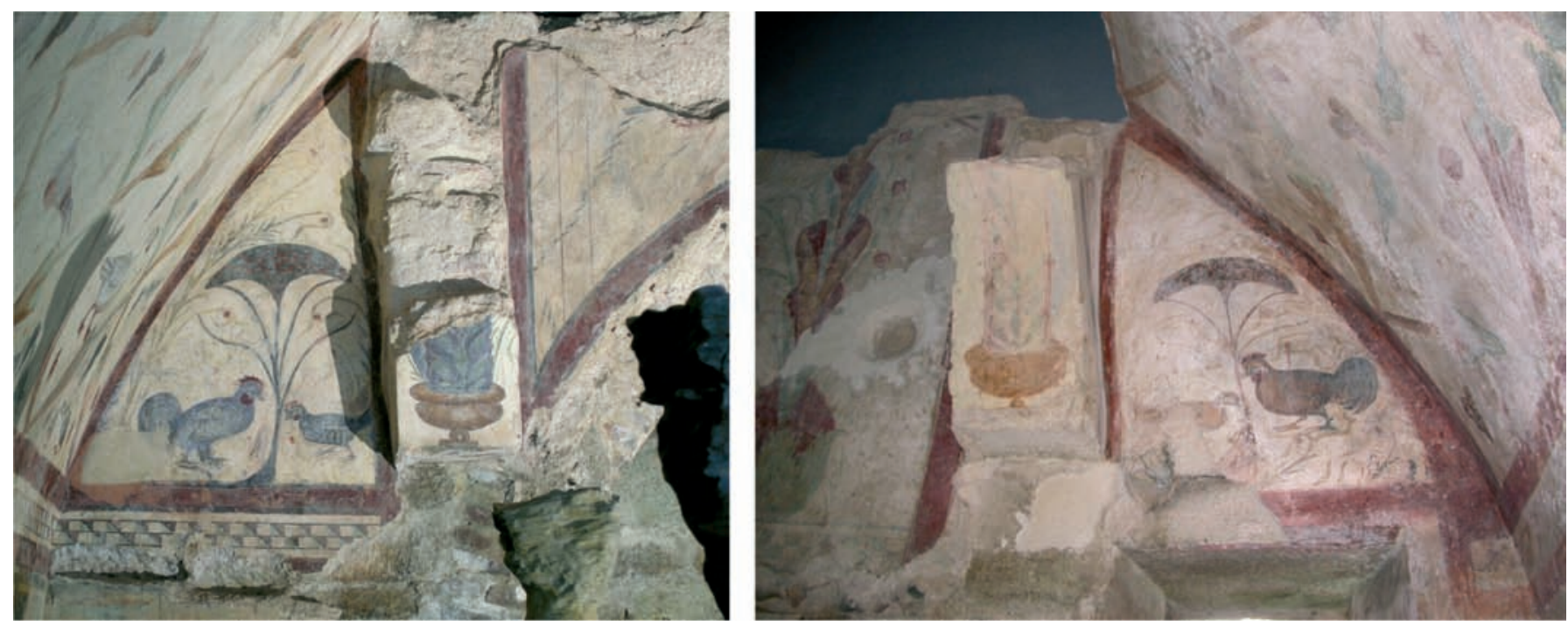

Fig. 15. Fotografías de los enjarjes $\mathrm{S}$ de los alzados W (imagen de la izquierda) y $\mathrm{E}$ (imagen de la derecha) en las que se pueden apreciar las deformaciones de los mismos $\mathrm{y}$ cómo la banda que enmarca las pinturas se adapta a éstas

allí los ladrillos son de distinta tipología). Los primeros ladrillos, los próximos al salmer, al igual que en el arco de la puerta de acceso, se disponen de forma ligeramente inclinada, mientras que hacia las partes altas conservadas lo hacen radialmente.

Uno de los aspectos que llama la atención de los restos de los arcos es la deformación que presentan, la cual se aprecia sobre todo en los enjarjes $S$ de los muros $\mathrm{E}$ y W, ya que son los que mayor altura conservan, aunque esta deformación está presente en los cuatro enjarjes. Del mismo modo, los tramos de bóveda conservada están también deformados, siendo más acusada la deformación del lado S. Inicialmente habíamos pensado que podían haberse producido por el colapso de la bóveda o la disposición sobre el muro $S$ del aula de la actual iglesia parroquial en el siglo XVIII.

No obstante, si estas deformaciones correspondieran a alguno de estos dos momentos, también tendrían que observarse en las pinturas grietas o roturas, pero las pinturas no presentan este tipo de patologías. Por lo tanto, tienen que haberse producido con anterioridad a la elaboración de las pinturas. Observando los arcos con detenimiento (ver figura 15), se puede apreciar cómo los mampuestos empleados en los enjarjes (sobre todo en el del muro W) son de mayor anchura que los ladrillos, generando un arco cuya rosca es irregular. De igual manera, el mortero que recubre los enjarjes tampoco presenta una superficie regular. Por otra parte, si la deformación resultase de la rotura de la bóveda o por el peso que ejerce la iglesia del siglo XVIII, tendría que haber generado unos empujes en el mismo sentido en los cuatro enjarjes y, sin embargo, estos son hacia el interior en los del paramento $\mathrm{E}$ y hacia el exterior en los del W (figura 16). Finalmente, el pintor intenta enmascarar las deformaciones adaptando a estas el ancho de la banda que enmarca las pinturas, generando un efecto óptico para corregir la deformación (ver figura 15). Todo ello nos lleva a concluir que las deformaciones de los enjarjes son de obra.

En cuanto a la bóveda, en el caso del lado $S$, el acusado pandeo (ver figura 9) tendría que ser también anterior a las pinturas, que tampoco presentan aquí grietas por asiento o roturas. Debemos recordar, como ya indicamos en la fase I, que los arcos fajones presentaban una inclinación desde la base. Pero la curvatura que hoy se observa, que cae casi recta desde aproximadamente la altura de la base de los enjarjes, está motivada por el engrosamiento del mortero (alcanzando hasta 9-10 cm), para lo cual se emplean incluso grandes fragmentos de ladrillo. Este engrosamiento no tiene otra funcionalidad que la de llevar la decoración pictórica hasta el grosor de las impostas de mármol y el friso que decoraba el edificio (ver figura 17). Este mismo engrosamiento se produce en los paramentos $\mathrm{E}$ y W, donde se genera una superficie cóncava por encima de la imposta.

Los arcos debían descansar sobre pies derechos, dos exentos y, posiblemente, dos adosados a los testeros en cada arquería. Para disponer las basas de estos elementos sustentantes sería necesario amortizar, como comentamos, la piscina o al menos disminuir sus dimensiones mediante la colocación de un enlosado. 


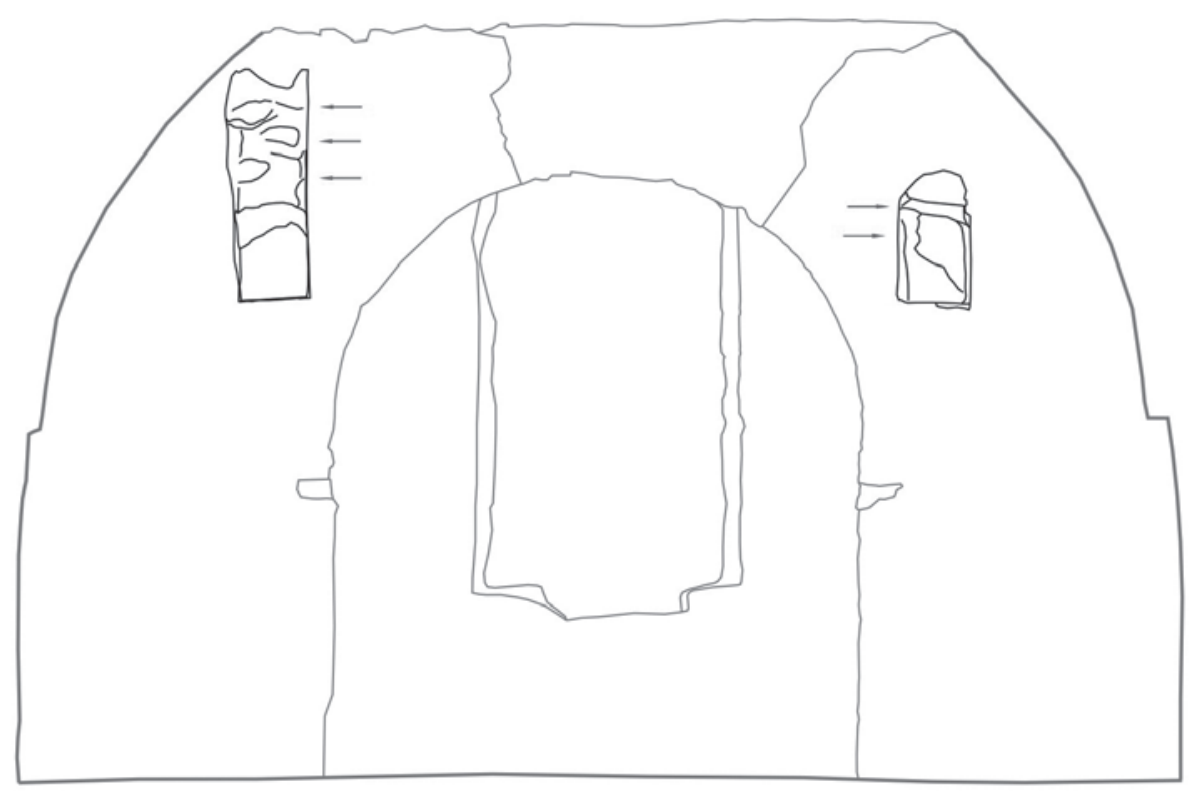

$1 \mathrm{~m}$

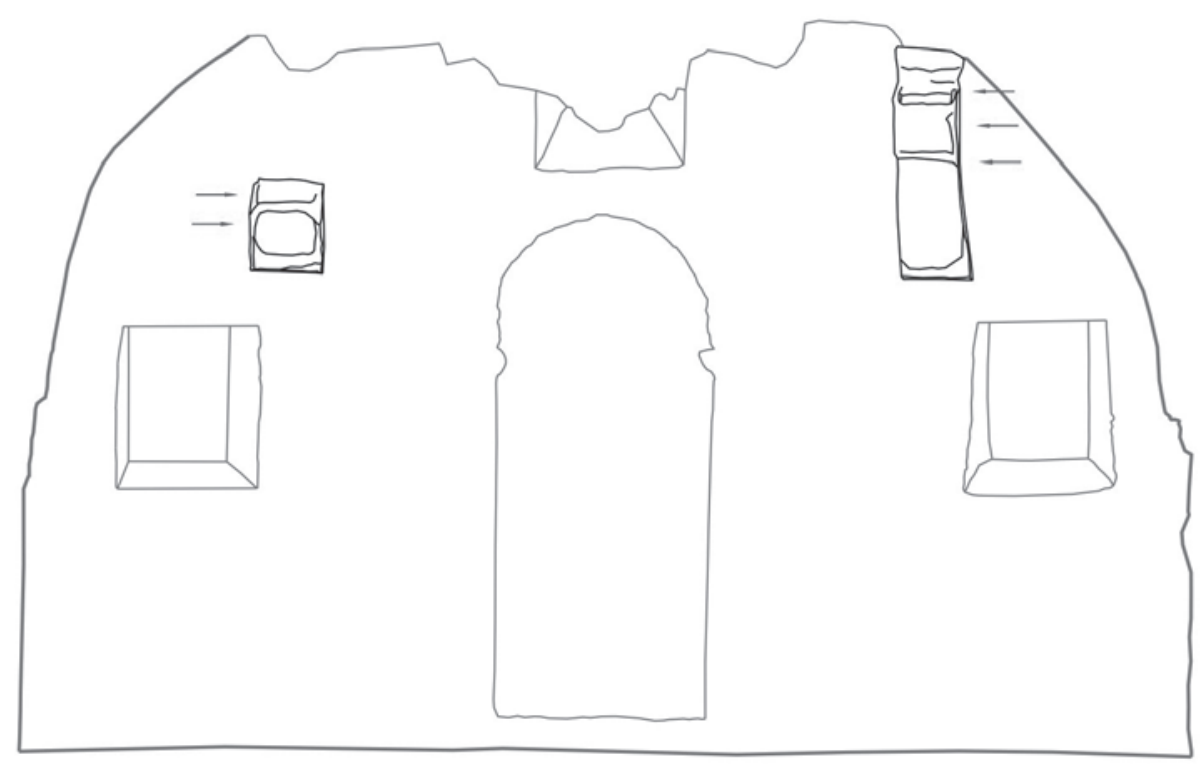

Fig. 16. Alzados E y W del aula. Las flechas rojas indican el sentido de la deformación que presentan los enjarjes, en el alzado W (imagen superior) hacia el exterior y en el $\mathrm{E}$ (imagen inferior) hacia el interior. También se pueden observar las deformaciones de los restos de la bóveda

La extraordinaria degradación parece indicar una erosión en la que participarían las sales y el viento, además de la humedad (ver figura 18$)^{19}$.

En el año 1929 (Montenegro, 2005: 26) se disponen en el entorno de la piscina tres columnas ${ }^{20}$ muy erosiona-

${ }^{19}$ Esta última causa ya fue atribuida por varios autores. Para que tal degradación se produjese por la acción del agua, mediante la disolución del carbonato cálcico, tendrían que haber estado sometidas a una escorrentía continua, lo que corrobora que no pueden pertenecer al aula, ya que nunca estuvo a la intemperie. El análisis petrográfico puede sacarnos de dudas porque la teoría sería diferente si se tratara de alabastro y no de caliza.

${ }_{20}$ Tanto los fustes como los capiteles parecen de roca caliza, pero están tan degradados que no podemos saber si se trata de un mármol local o de una caliza. En todo caso, el material nada tiene que ver con el que se emplea en las impostas das con sus respectivos capiteles, que fueron hallados durante las labores de excavación del interior del monumento, colmatado por tierra y escombros, considerando que formaban parte de las arquerías mencionadas. Sin embargo, si se observa la imagen que recoge Montenegro de este proceso (Id., 2008: 12), se puede apreciar cómo uno de los fustes recolocados en esa fecha se encontraba aproximadamente a la altura del arranque de la bóveda del ábside, es decir, en las zonas superiores del relleno, al lado

o en las placas decoradas halladas en el monumento, que son de un mármol muy blanco de cristales apreciables, ni tampoco con el mármol del Incio, documentado en monumentos romanos de Lugo. 

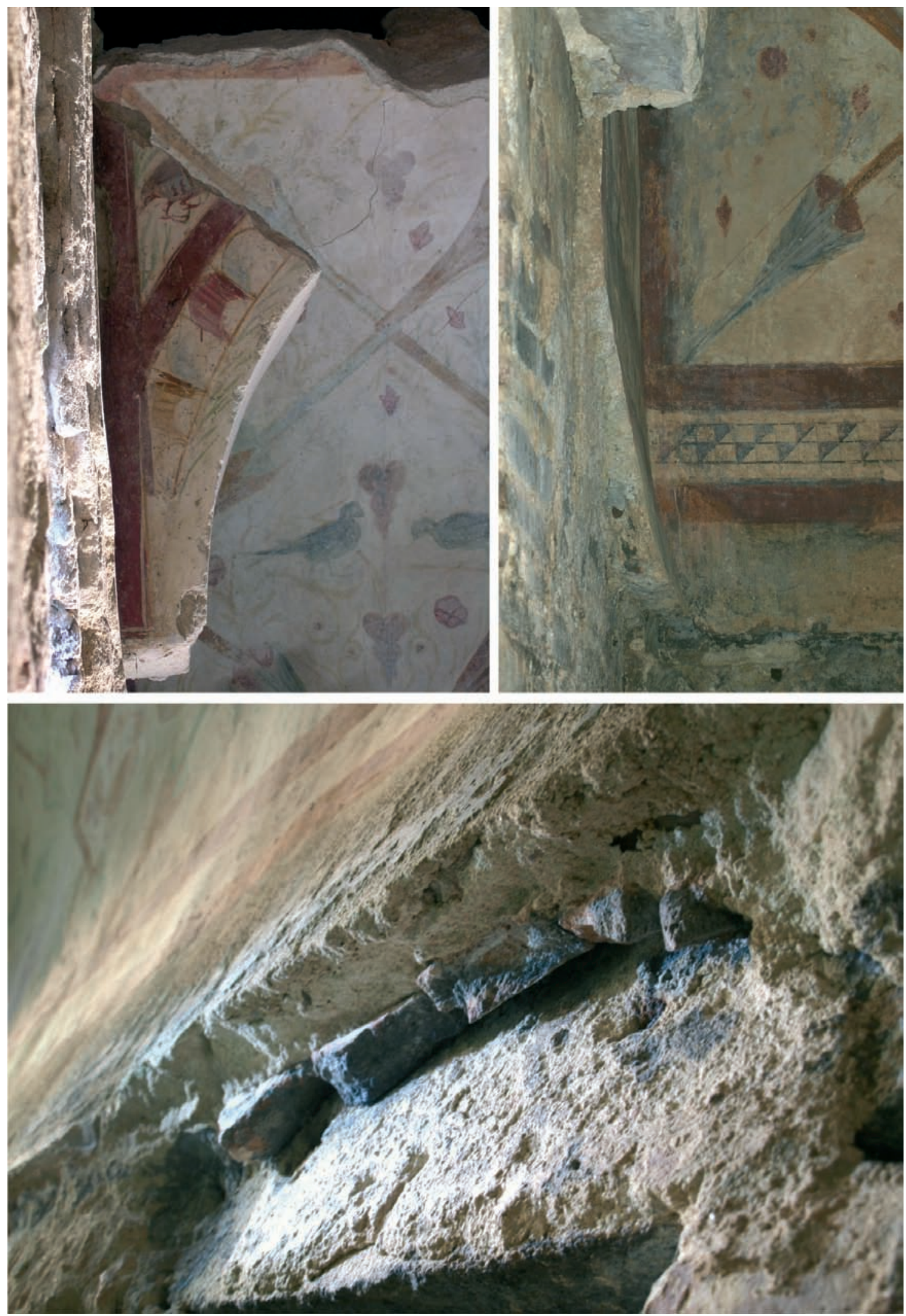

Fig. 17. Distintas fotografías de los revocos que cubren los muros del aula. En la imagen superior izquierda (muro E) se observan las distintas capas de mortero que se aplican. En esta rotura se puede ver una estratigrafía bastante completa de la preparación de las pinturas, en la que se distinguen, al menos, tres capas y el enlucido. En la imagen superior derecha (muro W) se puede apreciar cómo se engrosa el mortero, hasta llevarlo a la altura a la que se localizaría la imposta de mármol, que en esta zona se ha perdido pero permanece su impronta. En la imagen inferior (muro S) se pueden ver los fragmentos de ladrillo dispuestos bajo el mortero sobre el dintel de la hornacina. 

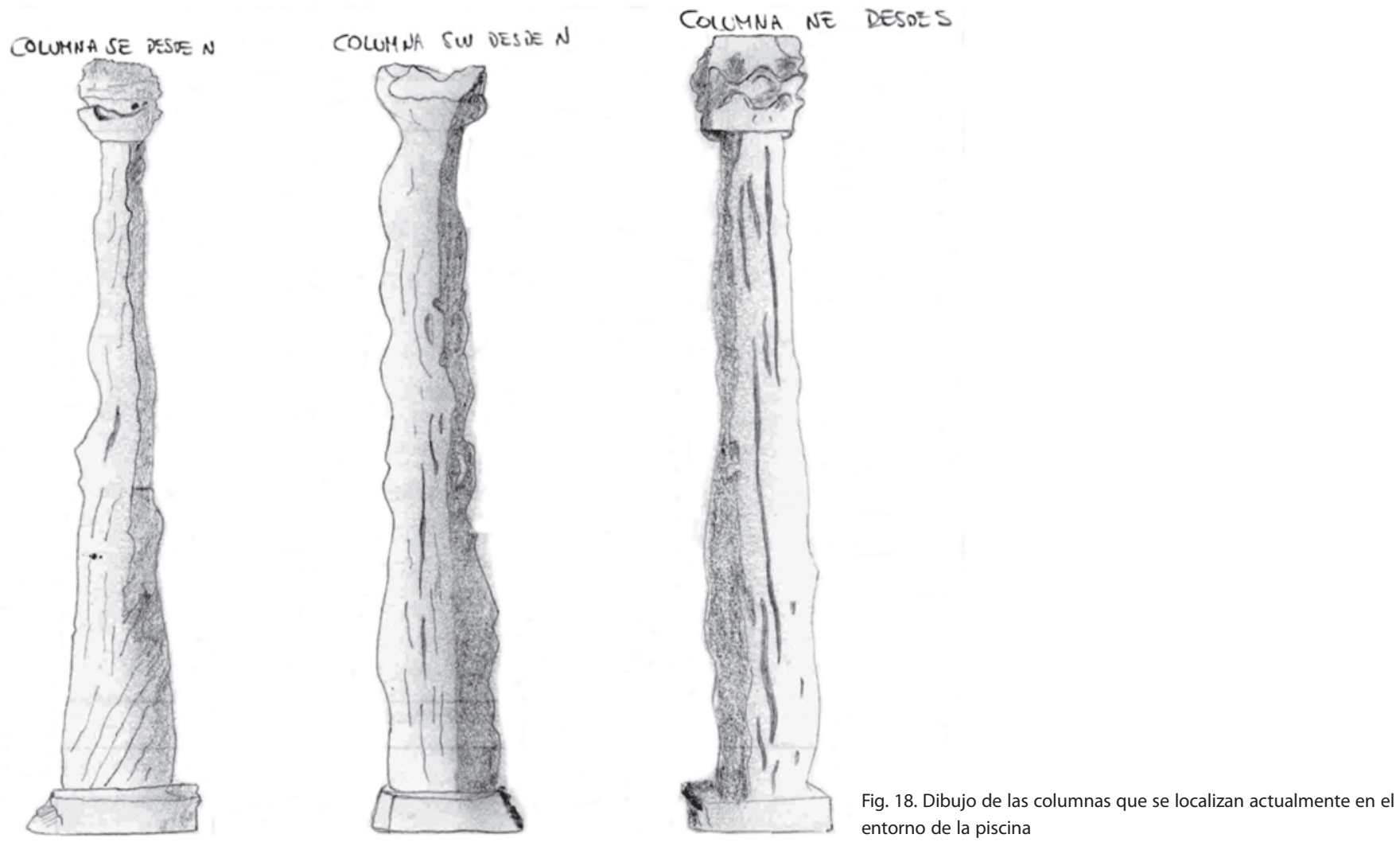

de varios fragmentos de la bóveda caída; por lo tanto, el relleno, al menos parcialmente, tiene que ser anterior a la fractura de la bóveda. Esta posición estratigráfica nos hace dudar de la pertenencia de este fuste al aula, siendo más lógico que provenga del piso superior.
La mayor parte de los autores consultados coinciden en llevar la división en tres naves a una etapa posterior a la original (ver nota 2), aunque, como en el caso de esta, existen bastantes controversias en cuanto a su adscripción cultural.

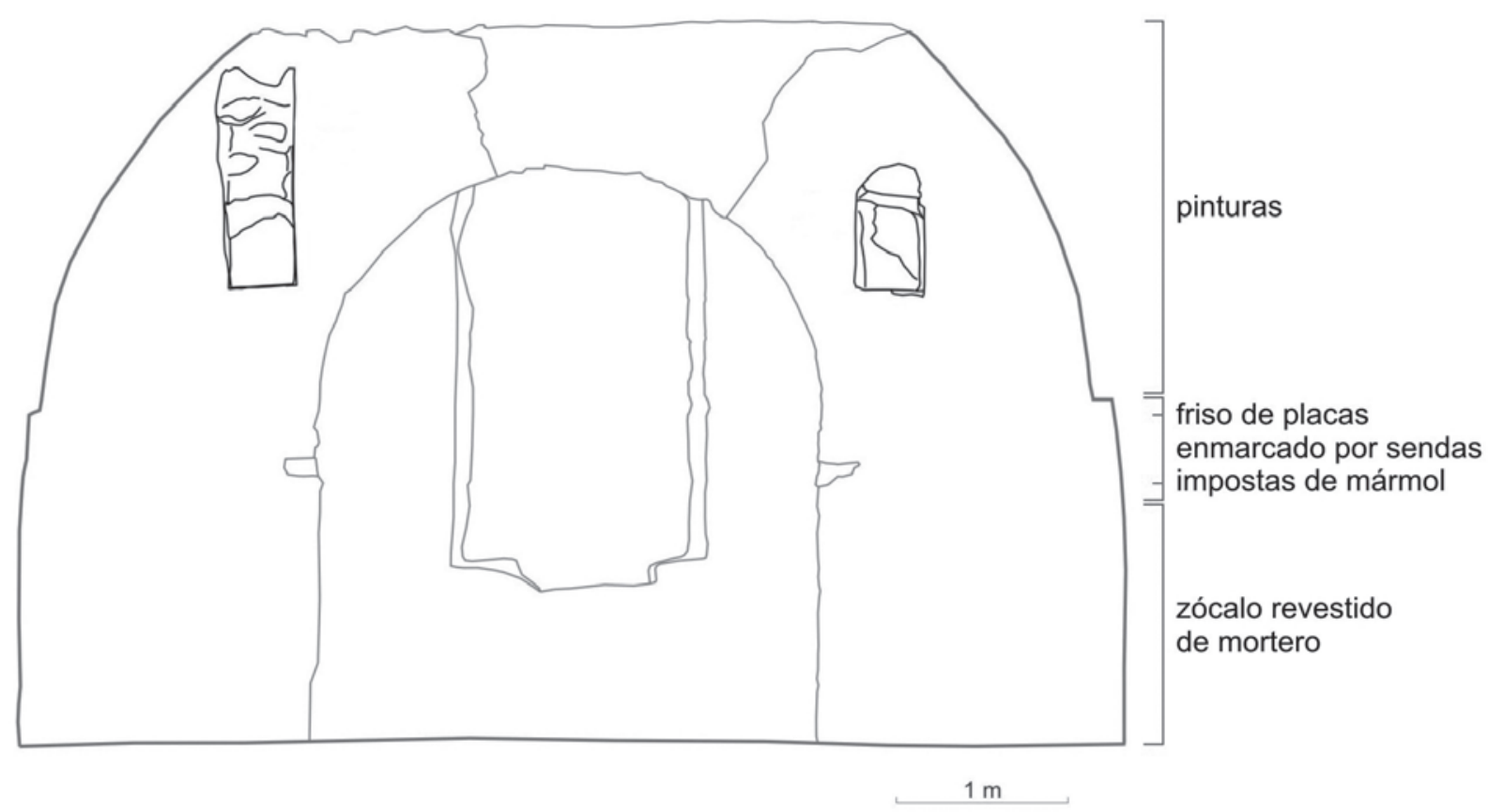

Fig. 19. Esquema de las diferentes partes que compondrían la decoración arquitectónica del interior del monumento en la planta baja 

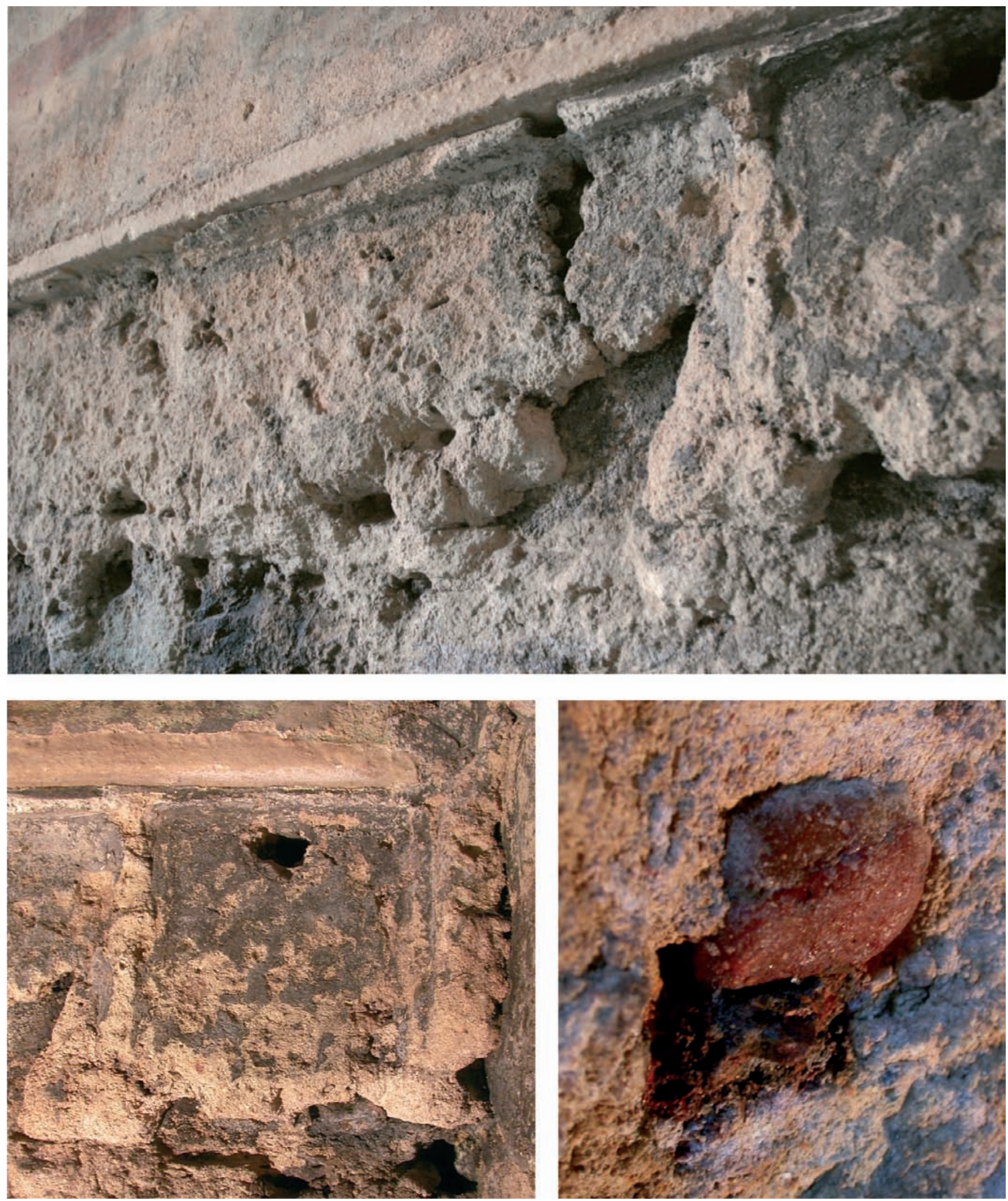

Fig. 20. En la imagen superior se presenta un detalle el alzado $\mathrm{S}$, en el que se aprecia, de abajo arriba, la impronta de la imposta inferior (por debajo de la cual se conservan fragmentos de mortero), los agujeros de los engarces, la imposta de mármol superior así como las improntas que han dejado las placas del friso. En la imagen inferior izquierda un detalle de una de las improntas de una placa y, en la derecha, de los restos de un engarce, compuesto por un fragmento de hierro y un canto de cuarzo 
En este momento, se acomete un programa iconográfico que incluye varios elementos decorativos en el interior del aula y el ábside. Únicamente conservamos in situ, algunos de estos elementos, concretamente las pinturas, parte de la imposta superior de mármol y parte del revestimiento de los alzados, pero gracias a las huellas dejadas sobre el mortero podemos reconstruir, al menos, los aspectos formales de aquella decoración. De abajo arriba, estaría compuesta por el enlucido de las paredes del aula que hemos denominado zócalo (ver figura 19) y, posiblemente, del ábside; de un friso de placas corrido en los paramentos $\mathrm{N}$ y $\mathrm{S}$ del aula y parte de los muros $\mathrm{E}$ (se interrumpiría a la altura de la puerta) y W (donde se interrumpiría a la altura de la rosca de la bóveda del ábside ${ }^{21}$, enmarcado por una doble imposta decorativa (suponemos que ambas serían de mármol, pero sólo conservamos la superior que es de este material); finalmente, sobre la imposta superior descansan las pinturas que recubren tanto la bóveda como las arquerías, empleando distintos motivos en las naves laterales y la central, como se comentará más adelante.

Los engarces de las piezas de las impostas y del friso se localizan a cuatro alturas, por debajo de la imposta inferior, por debajo y por encima de las placas del friso y por debajo de la imposta superior. En la primera lectura del edificio, únicamente habíamos detectado una doble línea que habíamos puesto en relación con el friso, pero nos llamaba la atención que en algunas zonas los agujeros no guardaban horizontalidad entre ellos. Una vez revisados los datos en los procesos interpretativos, nos hemos dado cuenta de que este hecho se debe a que realmente corresponden a las cuatro posiciones que acabamos de describir, que únicamente se perciben en algunos sitios del edificio, ya que parte del mortero de recubrimiento de los alzados se ha perdido o han desaparecido los elementos que rellenan estos agujeros, un canto de cuarzo y un fragmento de hierro (ver figura 20).

Por otra parte, las placas no debían presentar todas las mismas dimensiones a lo largo (aunque sí en altura) porque las improntas que se observan se localizan a intervalos irregulares. Uno de los aspectos que trataremos en el apartado siguiente es la revisión de las placas decoradas de mármol que se encuentran depositadas en el Museo Diocesano y Catedralicio de Lugo, trabajo que realizamos con la intención de obtener algún dato sobre este elemento decorativo y, sobre todo, comprobar si las placas allí conservadas podrían corresponder a este friso.

\footnotetext{
${ }^{21}$ En ambos casos, muros E y W, la imposta superior se localizaría a mayor altura que en los muros $\mathrm{N}$ y $\mathrm{S}$, concretamente sobre el límite superior de ésta.
}

En todo caso, la articulación de esta decoración genera la impresión de que la bóveda nace a mayor altura que la de la estructura original. Nuevamente, a través de la decoración, se está intentando enmascarar la verdadera estructura del edificio.

Habría que comentar también que el mismo tipo de engarces y su relleno se documenta en el intradós de la bóveda del ábside, donde se disponen toda una serie de agujeros irregularmente (ver figura 11). Ello nos hace plantear que probablemente esta bóveda estaba también recubierta por algún tipo de placa, pero, en este caso, no conservamos ninguna impronta que nos permita establecer una hipótesis sobre cómo sería esta decoración. Sin embargo, el tipo de agujeros y relleno documentados nos llevan a situarla en la misma fase que el programa iconográfico acometido en el resto del aula.

A esta fase correspondería también la apertura de dos hornacinas en los alzados $\mathrm{N}$ y $\mathrm{S}$ del aula que están cortando, para embutir sendos dinteles, los arcos fajones de la bóveda de la Fase I.

La reforma de la puerta afecta al umbral, las jambas, las mochetas, el arco de ligera herradura y la decoración que lo enmarca. Resultó bastante complicado documentar el corte que corresponde a la reforma de la puerta ya que, sobre todo en el interior, el mortero de las pinturas que recubrían el paramento impide ver, en muchas zonas, el límite entre el ladrillo que conforma el arco y la mampostería. Del mismo modo, las jambas por el interior no se encuentran a paño con el muro del aula; este espacio se recubre con un mortero de cal que impedía ver la totalidad del corte. Sin embargo, apreciábamos en algunas zonas de la puerta algunos cortes que nos llevaron a plantear la pertenencia de esta y el muro a dos momentos constructivos diferentes. Por el interior, donde no se conservaba el mortero, se aprecian repicados en la cara de los mampuestos donde se ubica la jamba y un corte a la altura de las mochetas. Además, en la parte baja del lado $S$ interior se documenta un agujero en el que se ha perdido uno de los mampuestos. La rosca exterior del arco, por el interior, es irregular, los ladrillos no presentan la misma longitud y en algunas zonas donde el mortero se había desprendido se observa el corte en los mampuestos. Por el exterior, la rosca está enmarcada por una moldura y entre esta y los sillares se conservan restos de mortero, únicamente en un sillar del lado $\mathrm{N}$, donde la rosca se ha partido, pudimos apreciar el corte. En este caso, la rosca exterior es regular. En cuanto a la zona de las jambas, únicamente se observa con claridad a la altura de las mochetas y en la parte baja del muro, para introducir el umbral que, por otra parte, presenta roturas 

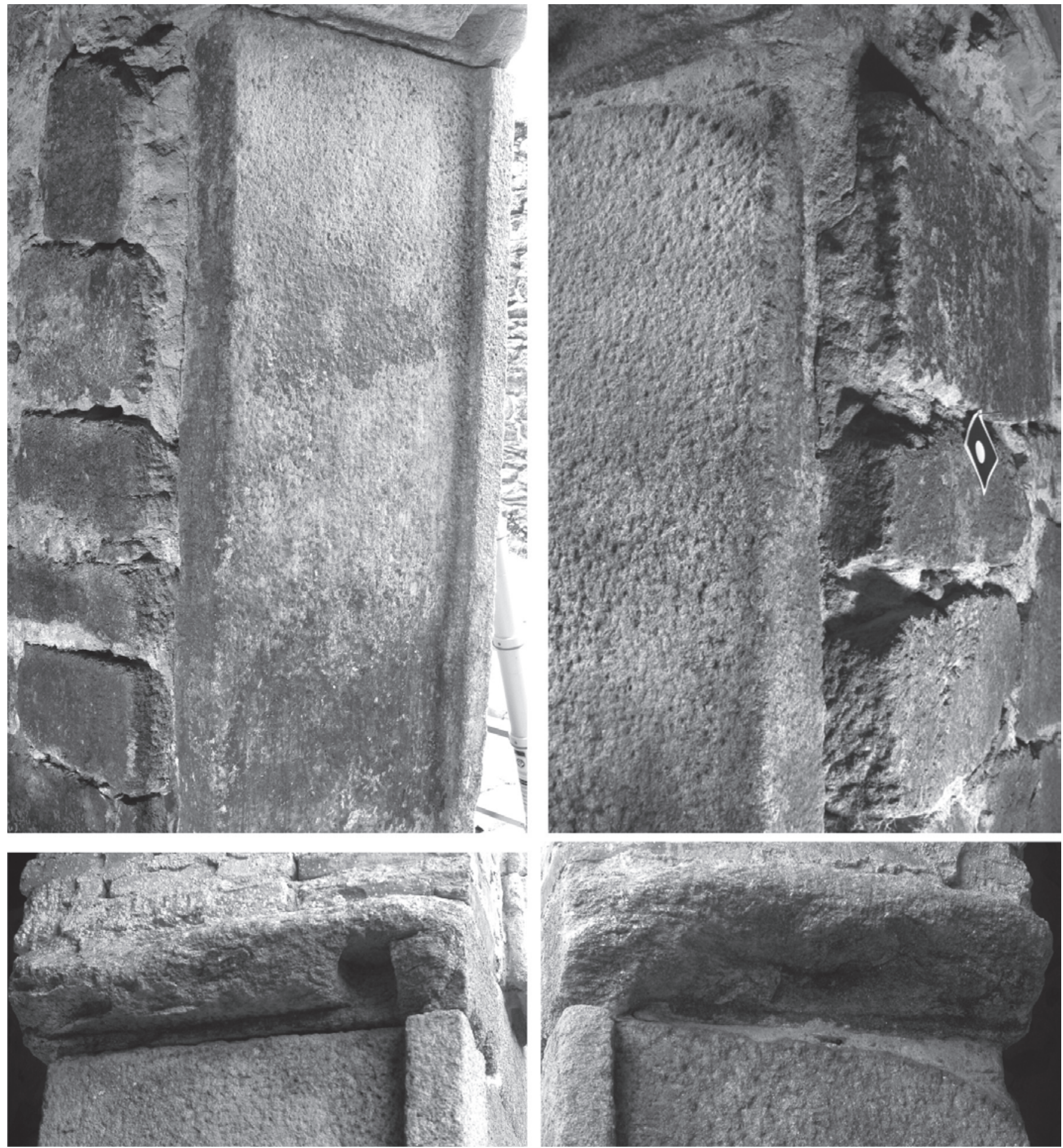

Fig. 21. Puerta E de acceso al aula. En las imágenes de la izquierda, jamba y mocheta $\mathrm{N}$ y en las de la derecha, jamba y mocheta $\mathrm{S}$. Se aprecian los cortes practicados en ambas piezas

en toda la superficie inferior (ver figura 6). La ausencia de cortes en las jambas nos lleva a plantear dos hipótesis, bien que no apreciemos el corte por el exterior al haberse adosado las piezas monolíticas de las jambas o bien que se estén adosando éstas y únicamente se corte el muro de la fase I para introducir el umbral, las mochetas y el arco, es decir, que el vano de la puerta de la fase II sea más estrecho que es de la fase I.

El arco que remata la puerta es de ligera herradura construido con ladrillo y junta de mortero de cal, en el cual 

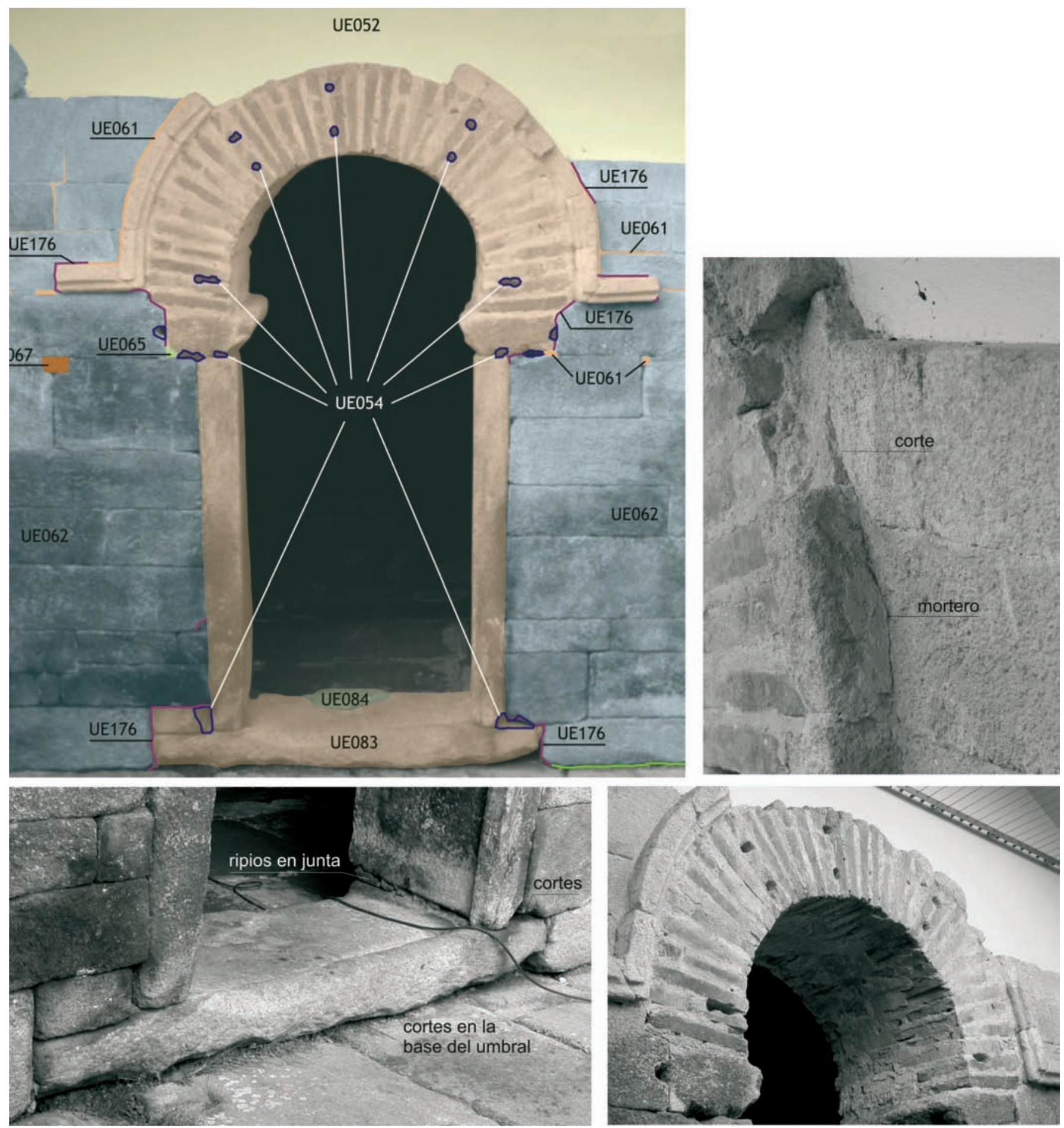

Fig. 22. Lectura estratigráfica y fotografías de detalle del exterior de la puerta

se conservan todavía las improntas de la cimbra. Los ladrillos miden de largo entre 37 y $29,50 \mathrm{~cm}$, de grosor entre 5 y $6,50 \mathrm{~cm}$ y de ancho oscilan entre 10 y $39,50 \mathrm{~cm}$, aunque algunos están cortados para adaptarse a las medidas del intradós del arco. Son más estrechos cuanto más próximos a la clave, pero no guardan la alternancia documentada en la rosca exterior de la bóveda del ábside.
La forma de hacer la rosca es la misma que la registrada en los enjarjes de las arquerías del aula, los primeros ladrillos se disponen inclinados y a medida que se aproximan a la clave, radialmente.

La rosca exterior del arco está cortada por varios agujeros (figura 23) que hemos puesto en relación con la colocación de una reja en la fase IV. Agujeros de similares 


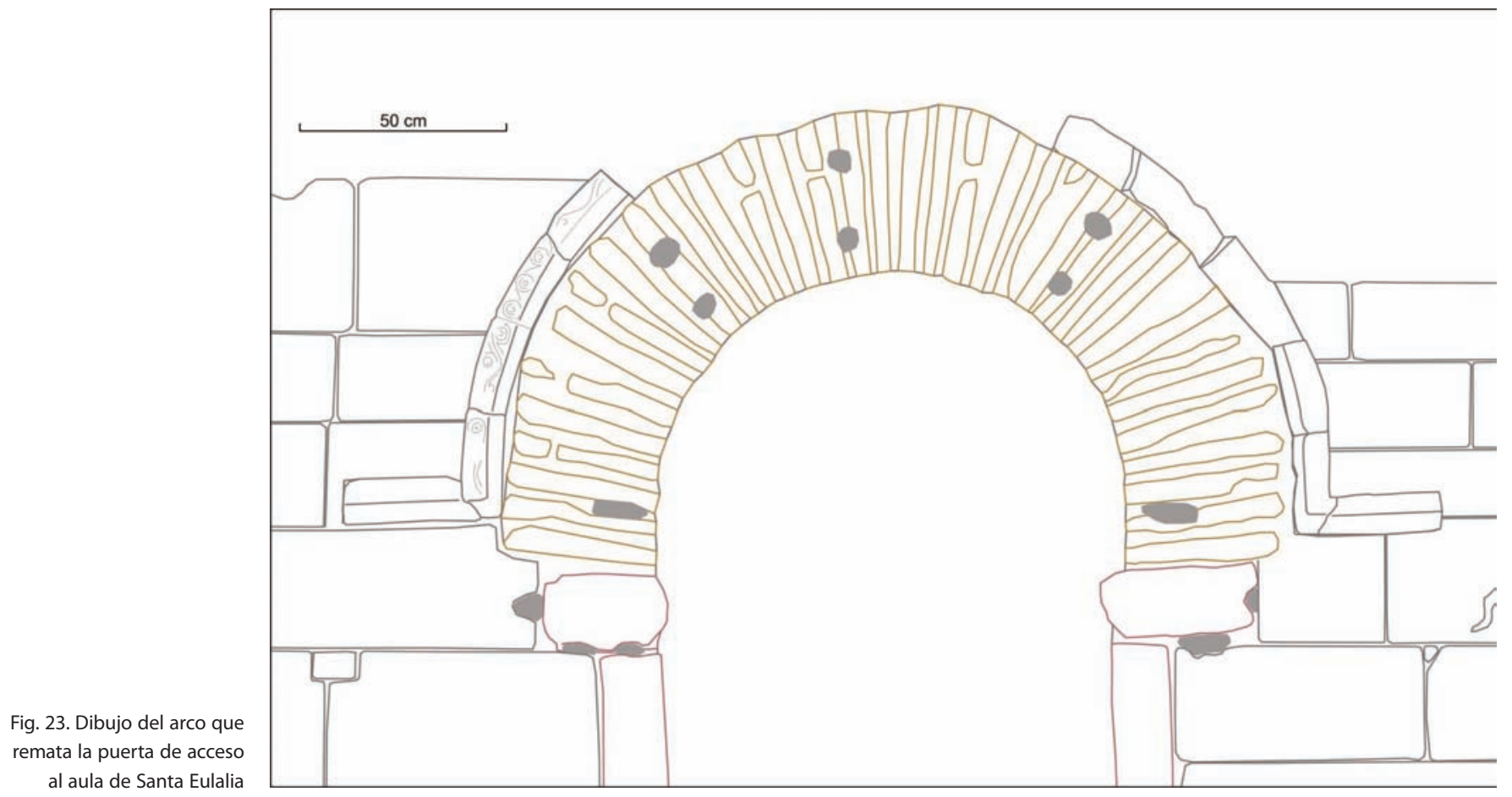

características y disposición se documentan también en la rosca del arco de ingreso al ábside.

El arco está enmarcado por una moldura que se adosa al extradós y tiene un perfil en listel, nacela y bocel. El listel está decorado con motivos vegetales incisos, a modo de roleos, aunque la decoración está muy erosionada y solo se aprecia en el lado $S$.

El arco descansa sobre sendas mochetas de granito, de perfil achaflanado e inclinadas en la parte superior. Algunos autores, entre ellos Gómez Moreno) han apuntado que las actuales mochetas serían el resultado de la rotura de un dintel «en el que antes encajaba la hoja de madera, provista de quicios, batientes y taladro lateral para pasador o cerrojo.» (Id., 1949: 418). Sin embargo, de haber existido efectivamente un dintel, este tendría un grosor excesivamente delgado como para soportar el vano que tiene que salvar, ya que, por lo que se aprecia en las mochetas, estas se han cortado para encajar los goznes y los batientes de la puerta, aunque quizás pueda haber sido este el motivo de la rotura del dintel.

Como comentamos, el umbral y las jambas están realizados con piezas monolíticas de granito que, en el caso de las segundas, se adosan al muro. Posiblemente las jambas, sobre todo la $S$, sean piezas reutilizadas, por el desgaste y corte que presenta en la parte superior. Llama la atención que las jambas, al interior, no están a paño con el muro, sino que se produce un retranqueo. De hecho, el muro interior tiene repicadas las piezas que se encuentran con las jambas. No pasa lo mismo al exterior, pero hay pequeñas piezas que parecen estar rellenando huecos al haberse eliminado los sillares, sobre todo en la jamba $S$. Sin embargo, las mochetas sí tienen la medida de todo el ancho del muro. Este dato podría llevarnos a plantear que inicialmente esta puerta tuviera la o las hojas de madera en el interior, y que los cortes que se documentan tanto en las mochetas como en las jambas sean posteriores.

Finalmente, se documenta además una reforma en las partes altas de los machones para la construcción de sendos dinteles que apoyarían sobre grandes columnas o pilares, aunque dudamos que estos elementos sustentantes sean los que actualmente se conservan, los cuales, por otro lado, se encuentran movidos con respecto a la posición original en la que se encontraron (una foto antigua de estas columnas se puede ver en Montenegro -2008: 14- en la que se puede apreciar la diferencia entre la posición actual y la de aquel momento), ya que no existe una correlación entre las dimensiones que tendría el dintel, que se corresponderían con las del machón, y las de las columnas. Otra posibilidad es que la solución adoptada para pasar de la anchura de los machones $(1,10 \mathrm{~m})$ a la de las columnas actuales (los tambores miden entre 33 y $38 \mathrm{~cm}$ de diámetro) sea similar a la empleada en el crucero de la iglesia de San Fructuoso de Montelios $^{22}$, donde grandes salmeres descansan sobre

22 Para esta iglesia se barajan tres cronologías: visigoda, mozárabe y fundación visigoda con restauración en el siglo XI (Utrero, 2006: 609-610). 

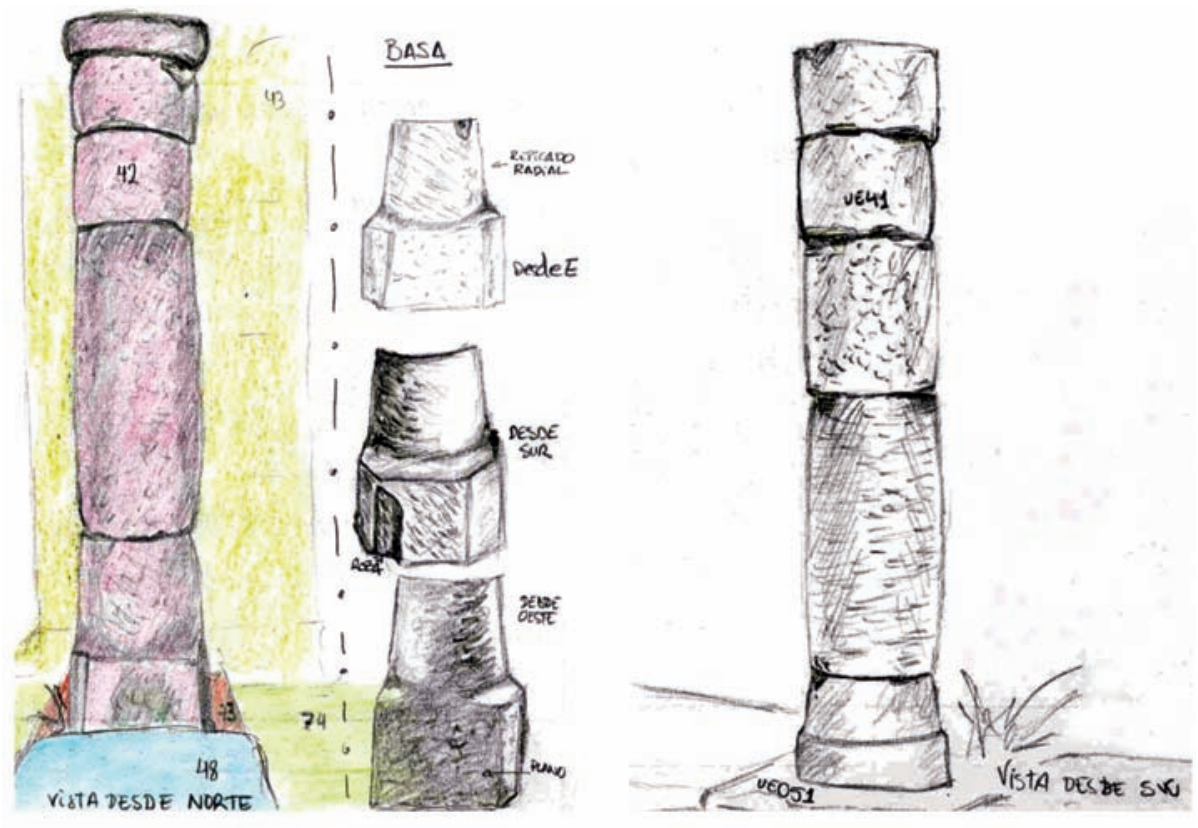

Fig. 24. Dibujos de las columnas que se localizan en la fachada del nártex. A la izquierda la $\mathrm{S}$ y a la derecha la $\mathrm{N}$ columnas con capiteles corintios de menores dimensiones que aquellos (Schlunk, 1947: 279, figura 299). En todo caso, en Bóveda llama la atención que las piezas que forman las actuales columnas tienen diferentes dimensiones entre sí (con diámetros irregulares), diferente éntasis y distintos repicados en varias direcciones, siendo también distintas las basas (figura 24). Por lo tanto, estarían realizadas con materiales reutilizados, procedentes posiblemente de varios pies derechos.

Como hemos comentado, la bóveda que actualmente cubre este espacio se realiza con posterioridad a esta fase, ya que se ha documentado una roza que corta tanto la fachada E del aula como los machones, para encastrar esta bóveda. De igual manera, para disponer las molduras sobre las que descansa, también reutilizadas, ya que existen diferencias tanto a nivel formal como de tamaño entre las piezas empleadas, se cortan los sillares de los paramentos $\mathrm{N}$ y $S$ del nártex.

\section{Fase III}

«El comportamiento mecánico, junto a las frecuentes acciones voluntarias de cambio, es el culpable habitual de determinadas transformaciones arquitectónicas como las grietas, los pandeos, los movimientos de los muros o las ruinas de los conjuntos.» (Utrero, 2006: 47).

La fase III corresponde a la construcción de un segundo piso sobre el aula abovedada. No podemos saber si este segundo piso se realiza porque se produjo un colapso de la estructura anterior (debemos recordar que apuntába- mos la existencia de dos pisos ya desde la primera fase) o de una reforma de esta, porque los escasos restos que conservamos no nos permiten ir más allá en la interpretación. Tampoco podemos saber en qué momento se produce exactamente esta ruina.

Por otra parte, ya habíamos comentado la dificultad que tenemos en la actualidad para vincular los restos del piso superior con lo que conservamos en el aula, ábside y nártex de las fases anteriores, puesto que hemos perdido la conexión estratigráfica que existía entre ellos. Lo cierto es que, a medida que avanza la investigación sobre este conjunto y que vamos teniendo resultados de las analíticas realizadas, todo parece apuntar a que existen bastantes diferencias entre el piso superior y el inferior como para considerarlos coetáneos.

De este segundo piso se conservan únicamente los restos del muro $\mathrm{N}$ del arranque de la bóveda, elemento que constituía el objetivo principal de la intervención llevada a cabo por César Portela entre 2006 y 2007, enfocado hacia su conservación. La intervención consistió en la construcción de una estructura en acero y cristal que protegiese estos restos.

La lectura estratigráfica únicamente se pudo realizar in situ en el paramento $\mathrm{S}$, el que correspondería al interior de la estructura abovedada, ya que el $\mathrm{N}$ está actualmente oculto por un geotextil y un recubrimiento de mortero de cemento. Para realizar la lectura de su cara $\mathrm{N}$ tuvimos que recurrir a las fotografías efectuadas antes de la disposición del recubrimiento en las que se podía apreciar con bastante 

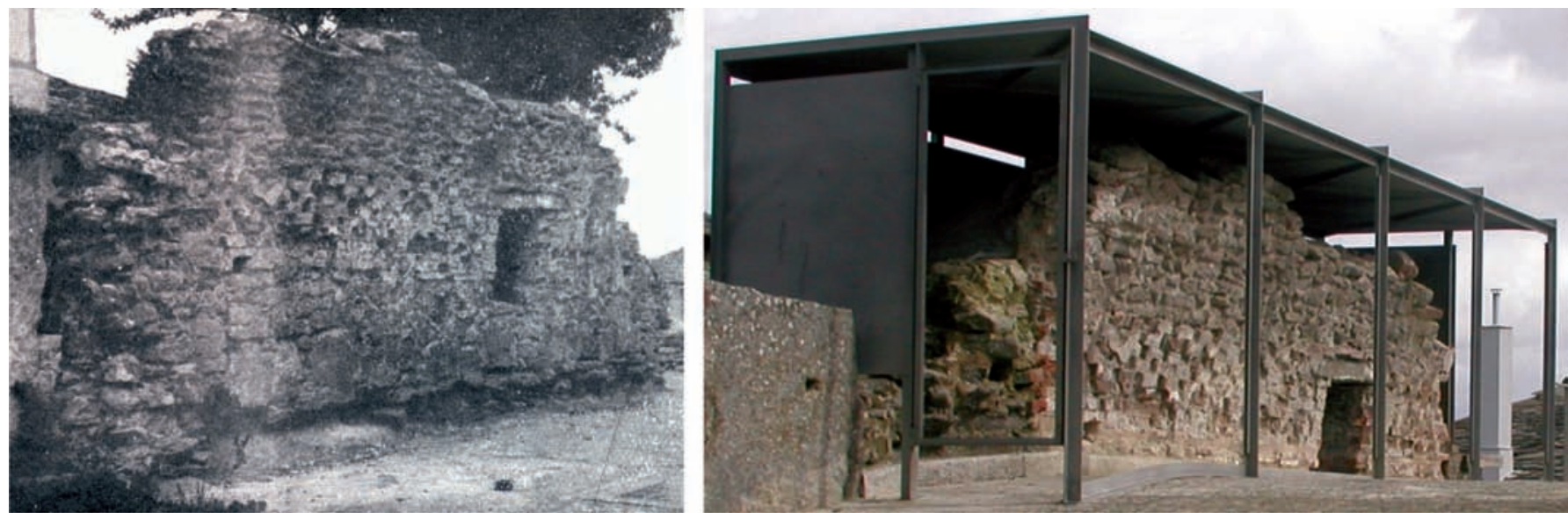

Fig. 25. Fotografías de los restos del piso superior, la de la izquierda está fechada en los años 50 del siglo xx (Chamoso, 1952) y la de la derecha es del estado actual

nitidez su estratigrafía, que confirma los datos registrados en la cara $S$.

La estratigrafía registrada corresponde a tres momentos distintos, aunque posiblemente dos de ellos sean coetáneos y las diferencias sean únicamente por los materiales empleados. De la fase que nos interesa aquí se conservan los restos del arranque de una bóveda realizada con ladrillos de entalle tomados con mortero de cal en el intradós y mampostería con abundante mortero también de cal en el trasdós. El grosor de los ladrillos oscila entre los 5,5 y los $7 \mathrm{~cm}$ y su largo entre los 24 y los $25 \mathrm{~cm}$.

Estos ladrillos, por su morfología, dimensiones y técnicas de fabricación semejan ser de factura romana y algunos autores han apuntado su posible reutilización (Vidal Caeiro, 2003: 244), hecho que ya habíamos puesto en duda anteriormente (Benavides y Blanco-Rotea, 2008: 61). Por otra parte, el ladrillo de entalle romano responde a un uso muy concreto dentro de las bóvedas, cuyo esquema teórico se puede consultar en Pérez Losada (1992), para formar arcos fajones superponiendo los ladrillos a modo de dovelas. En este caso los entalles de un ladrillo se colocan en la misma posición que los del siguiente y el anterior. En Santa Eulalia, la bóveda de la planta alta es corrida, sin arcos embebidos y todo el intradós está realizado con este
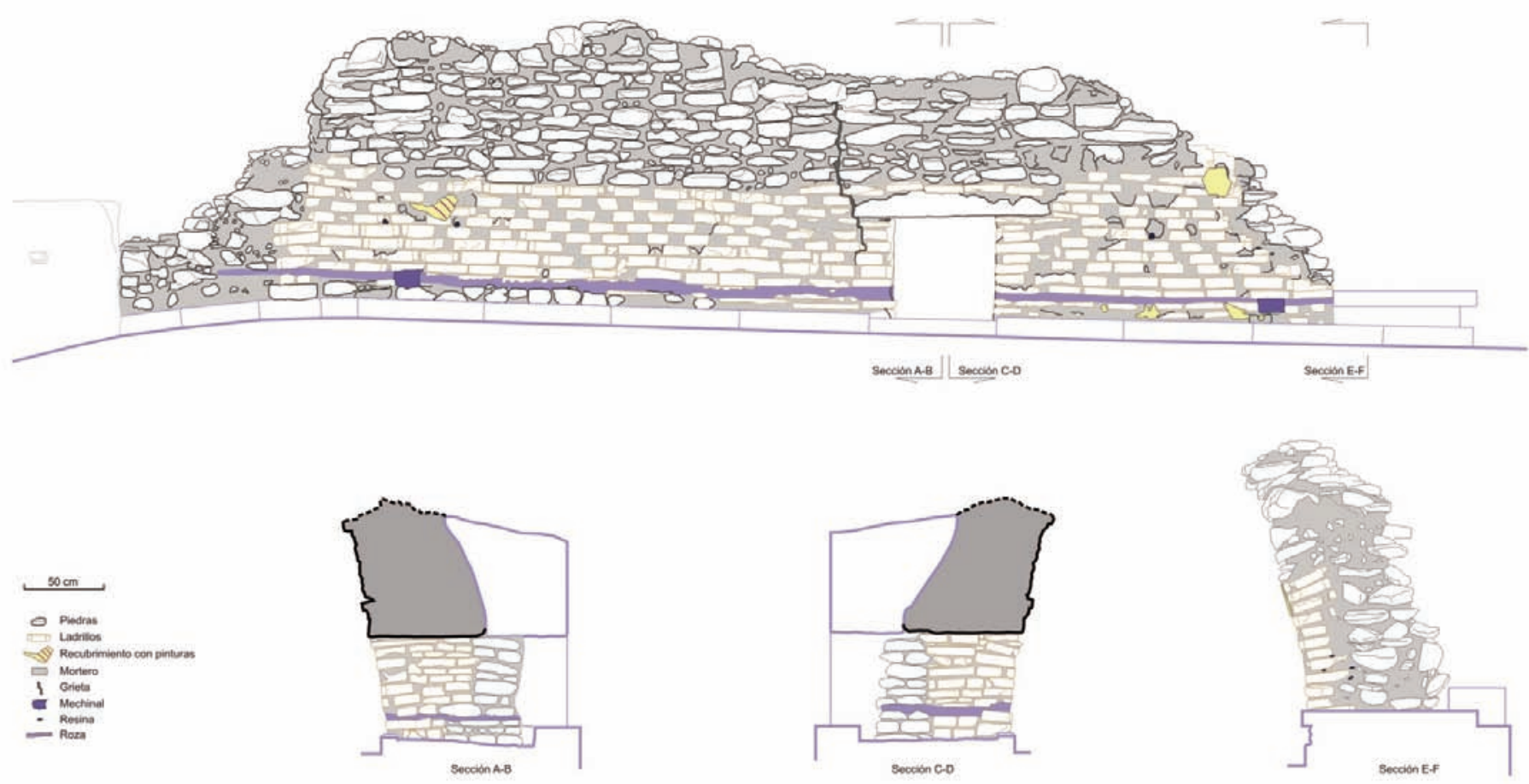

Fig. 26. Alzado y secciones de los restos conservados en la planta alta 


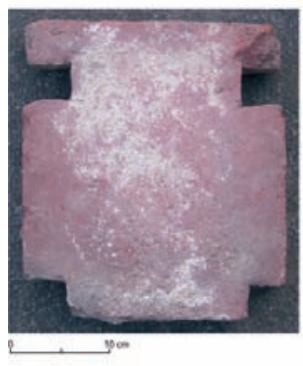

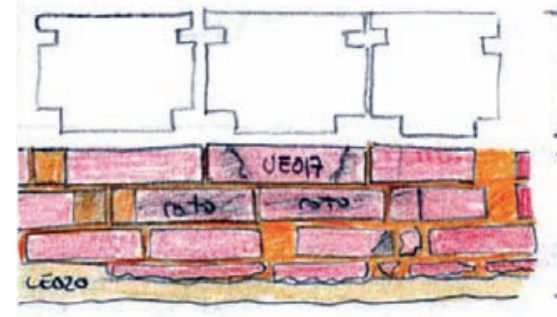

Despiece del aparejo

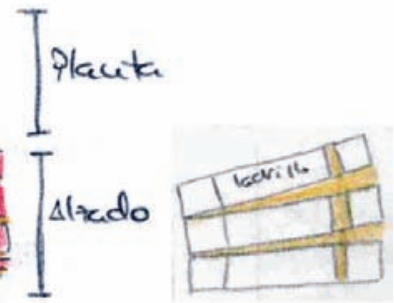

Sección
Fig. 27. Fotografía de un ladrillo de entalle de Santa Eulalia de Bóveda, recuperado durante las intervenciones en el edificio y localizado actualmente en el centro de recepción de visitantes de este conjunto monumental. Croquis del sistema de la disposición de los ladrillos de entalle empleado en la bóveda tipo de ladrillo, que se dispone en hiladas horizontales continuas, alternando entre la hilada inferior y la siguiente la coincidencia del entalle, de modo que al exterior los entalles forman un reticulado. El hueco de estos entalles parece utilizarse para que agarre el mortero de cal que recubriría el intradós de la bóveda sobre el que se dispondrían las pinturas, aunque este mortero es posterior, de la fase IV y, por lo tanto, el dibujo reticulado podría encontrarse originalmente visto.

Además, el ladrillo se dispone radialmente, con una junta muy fina hacia el intradós de la bóveda que va aumentando hacia el trasdós gracias al empleo de mortero. De este modo, por los entalles traseros de la pieza se cuela el mortero, cohesionando así toda la superficie.

La rosca, como se decía, está realizada en una mampostería con piezas de granito irregulares de tamaño medio con abundante mortero de cal. Los morteros del intradós y el trasdós tienen ligeras diferencias, como se verá en el apartado correspondiente, pero posiblemente esto esté más relacionado con su función que con la pertenencia a momentos distintos.

La bóveda se apoya sobre un muro de mampostería del que poco podemos decir, ya que ha quedado oculto bajo el forjado de hormigón que cubre actualmente el edificio de la planta baja. Por lo que se puede apreciar en las fotografías cedidas por José López Fernández, efectuadas durante la restauración de los arquitectos José Manuel Gallego Jorreto y César Portela Fernández-Jardón en los años 1985-1993, se trata de un muro de mampostería irregular realizado con mampuestos de tamaño medio, aunque también se documenta alguno de mayor tamaño, tomados con mortero de cal. En una fotografía de López Martí (1927: 58) se aprecia en este muro una roza que lo recorre de $\mathrm{E}$ a W que, por su posición, parece el lugar en el que se encastraría el suelo de este espacio, que semeja situarse aproximadamente a algo menos de un metro por debajo de la ventana adintelada que todavía hoy existe.

Asimismo, se conservaba todavía en ese momento el arranque del muro W. En la actualidad, tan solo podemos observar las hiladas superiores de este muro. Se trata de hiladas de regularización realizadas con losetas de ladrillo, muchas de ellas fragmentadas, y sobre estas se dispone la bóveda.

La parte superior de este muro se regulariza con ladrillos y losetas, en algunos casos fragmentados. Los ladrillos tienen entre 5,5 y $6 \mathrm{~cm}$ de ancho y unos $24 \mathrm{~cm}$ de largo, aparentemente son sin entalle, mientras que las losetas miden entre 3 y $3,5 \mathrm{~cm}$ de grosor y entre 41 y 43 $\mathrm{cm}$ de largo, las que parecen enteras. En cuanto al arranque del muro W, tan solo podemos apreciar en la esquina inferior NW los restos de este, que miden aproximadamente $1 \mathrm{~m}$ de grosor y coinciden sobre los alzados del ábside del piso inferior, lo que hace que el edificio de la planta alta fuera de menores dimensiones por el W que el de la planta baja; del mismo modo, tenía menor anchura (ver figura 3). Por el E, sin embargo, como ya comentamos, debía adelantarse hasta el nártex.

La reconstrucción de la bóveda del piso superior que hemos realizado a partir de la topografía de alta resolución genera una bóveda de cañón de medio punto, que tendría menor altura que la del piso inferior, ya que está cubriendo un espacio de menores dimensiones.

No sabemos cómo se realizaría la comunicación entre ambos pisos en la fase III y mucho menos en las anteriores, o si se trataba de plantas independientes. La puerta localizada en el muro W del ábside de la que partían unas escaleras hacia el piso superior que fueron eliminadas durante las primeras intervenciones, por considerarse un añadido posterior al monumento ${ }^{23}$, la hemos englobado en la fase IV por el tipo de arco de remate que presenta.

Los otros dos momentos documentados en este muro, a los que nos referíamos al principio, constituyen una reforma en el lado $\mathrm{E}$ en la que se emplean los mismos materiales que en la bóveda original del piso superior,

${ }^{23}$ López Martí (1928: 323). En esta imagen se observa cómo las escaleras giraban hacia el S. Durante el proceso de desmontaje de las escaleras se recupera un fragmento de estela funeraria fechada en época romana que estaba reutilizada como peldaño (Id.: 324). 
aunque con ligeras diferencias en la disposición de los ladrillos y otra reforma realizada en un aparejo de mampostería que continúa la curvatura de la bóveda y que incluye una ventana adintelada. Ambas parecen corresponder a la reconstrucción de la bóveda que se habría fracturado a partir, aproximadamente, del riñón.

\section{LA DECORACIÓN ARQUITECTÓNICA DE SANTA EULALIA DE BÓVEDA}

\section{Apuntes sobre la decoración escultórica}

No nos proponemos hacer aquí un estudio en profundidad de la decoración escultórica de Santa Eulalia, ya que requeriría un análisis más detallado que el que hemos efectuado, pues no era este uno de los objetivos planteados inicialmente, pero sí nos parecía interesante hacer algunos apuntes sobre determinados aspectos de esta decoración que pueden estar en relación con la evolución constructiva del edificio.

Con la excepción de los bajorrelieves que se localizan in situ, la restante escultura decorativa de Santa Eulalia de Bóveda está descontextualizada y únicamente sabemos que, la mayor parte, procede del desescombro realizado en el edificio y su atrio durante las primeras intervenciones, por lo tanto, es difícil vincularla a una u otra fase constructiva. Este es uno de los aspectos que sigue dificultando la datación del edificio que, a no ser por las pinturas con toda la problemática que conllevan, carece de indicadores cronológicos más allá de las técnicas empleadas o de la tipología de sus elementos.

\section{Bajorrelieves in situ}

En los muros del nártex de Santa Eulalia se localizan varios bajorrelieves que han sido ampliamente estudiados con anterioridad ${ }^{24}$ y que han servido a varios autores para aportar una funcionalidad al edificio. Pongamos por caso el relieve denominado «de los lisiados», situado en el muro $\mathrm{N}$ del interior del nártex, en el que se representan dos figuras humanas masculinas enfrentadas, que se ha puesto en relación con las posibles propiedades curativas de la piscina de Bóveda.

En todo caso, no nos interesan tanto aquí los motivos representados o su funcionalidad, sino la relación de estos con el monumento como arquitectura.

${ }^{24}$ López Martí (1927, 1934), Martínez Morás (1927), García y Teijeiro (1933), Gómez Moreno (1949), Chamoso Lamas (1952), Ares Vázquez (1962, 1963, 1964, 1984), Acuña Castroviejo (1973), Arias Vilas (1980), Rodríguez Colmenero (1992), Montenegro (2005) o Vidal Caeiro (2006).
En la fachada del nártex se localizan cuatro bajorrelieves situados en una posición predominante, ya que es lo primero que el visitante observa del edificio. Estos son los únicos de todo el conjunto que guardan una simetría con respecto a la arquitectura de esta zona del edificio y entre sí. Nos referimos a los dos grupos de danzantes y a las dos figuras humanas, interpretadas como masculina y femenina, respectivamente. Estos cuatro relieves son los que presentan una talla más profunda, en relación con todos los que se conservan, y una mayor profusión decorativa. Están además enmarcados por una arquitectura, las figuras aisladas se disponen entre dos columnas que soportan un dintel. Ambas figuras tiene los brazos levantados y sostienen una guirnalda. Se sitúan en la cuarta hilada desde abajo, en un tizón, en la esquina del machón.

Dos hiladas por encima de estás se disponen los bajorrelieves de «danzantes», formados por cinco figuras enmarcadas también por una arquitectura, en la que se aprecia la línea de base y un elemento sustentante que las delimita por los lados y en la parte superior otro posible dintel, de manera similar a lo descrito arriba. El bajorrelieve del machón $S$ está bastante erosionado.

Lo que nos interesa destacar de este grupo es que está tallado con anterioridad a la disposición del sillar en el machón, pues todos se encuentran a paño con los del resto del muro y no se aprecian huellas de talla más allá del acabado final del sillar que está apiconado, mientras que los bajorrelieves sobresalen del paño del muro. Por otra parte, las representaciones están centradas con respecto a la cara del sillar en la que se labran.

Por el contrario, los otros relieves que se aprecian, cuatro en total ${ }^{25}$, se disponen de manera aleatoria y sin aparente concierto en la fachada del machón $S$ y en los paramentos interiores del nártex. Tres corresponden a figuras animales y el cuarto presenta figuración humana. Ninguno de ellos está enmarcado por un elemento delimitador como en el caso de los bajorrelieves comentados arriba.

Nos interesan en concreto dos, el de un ave identificada como ibis (Montenegro, 2008: 30) que descansa sobre un árbol y oculta la cabeza debajo de las alas y el bajorrelieve denominado de los «lisiados» donde se representan dos figuras humanas enfrentadas, ya que de los cuatro son los que presentan un mejor estado de conservación y en los que se aprecian tanto los motivos como las huellas de talla.

\footnotetext{
${ }^{25}$ Vidal Caeiro apunta la existencia de otros dos bajorrelives en la fachada E de
} los machones, pero nosotros no hemos podido localizarlos (Id., 2006: 34-38). 

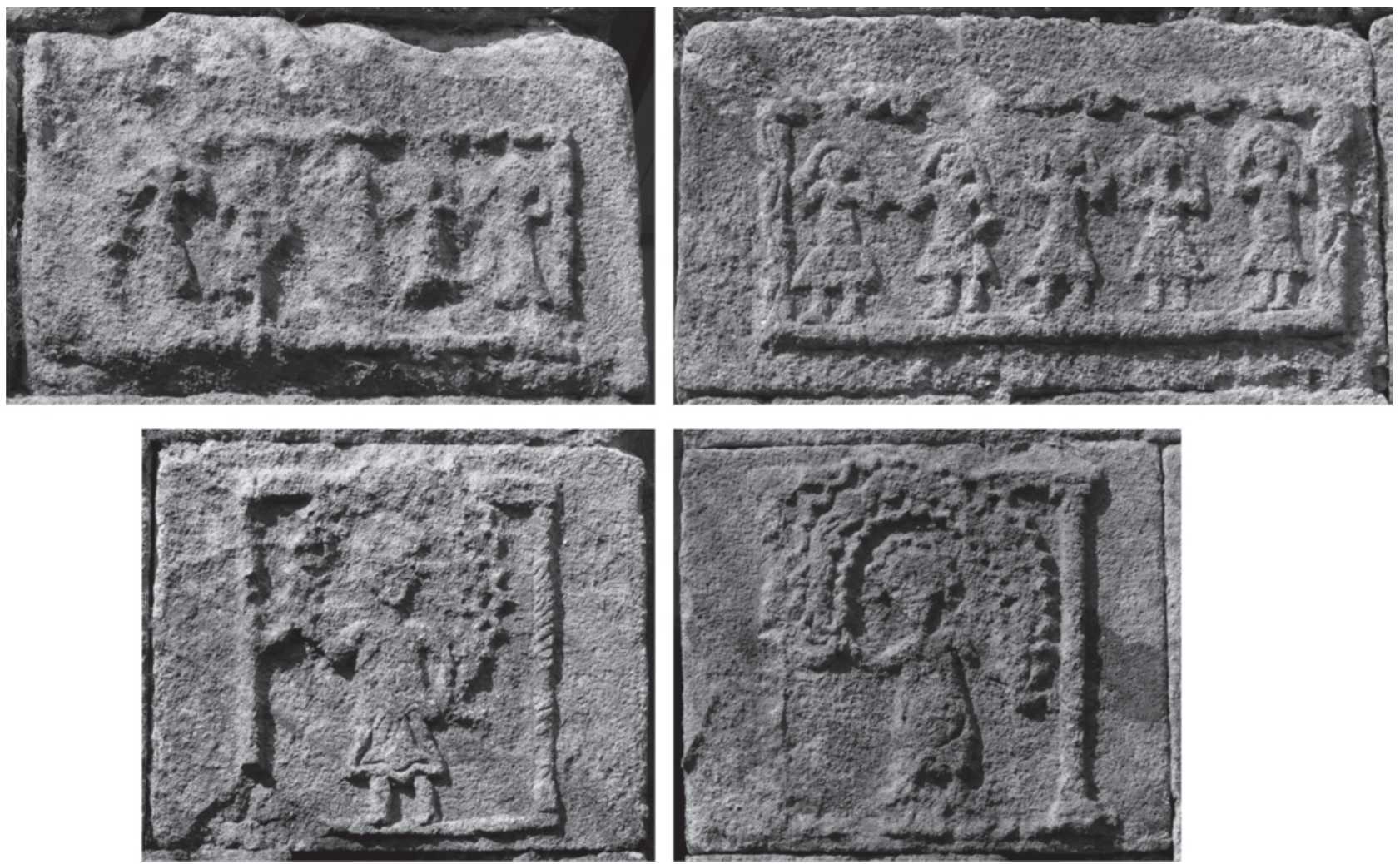

Fig. 28. Fotografías de los bajorrelieves localizados en la fachada de los machones del nártex
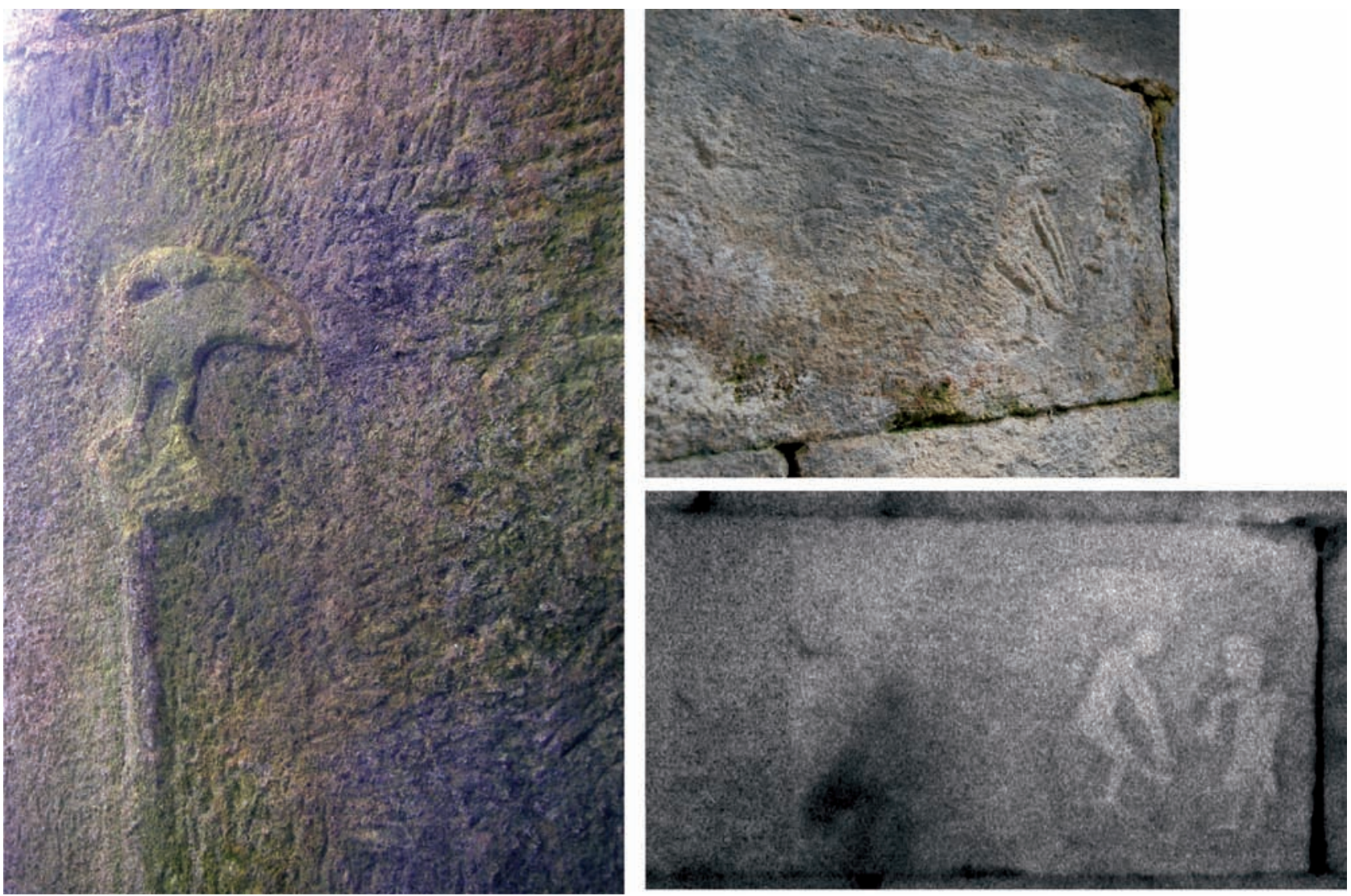

Fig. 29. Fotografías de los bajorrelieves del «ibis» y «los lisiados». La imagen inferior derecha corresponde a la nube de puntos obtenida del escaneado del bajorrelieve de «los lisiados». En ella se puede apreciar cómo una parte del sillar tiene una coloración más clara que corresponde a la zona grabada 
El primero se localiza en el muro W del machón S; concretamente está labrado en el mismo sillar en el que por la fachada se dispone uno de los bajorrelieves arriba descritos con la figura masculina que porta una guirnalda. El segundo, en el muro $\mathrm{N}$ del espacio interior del nártex. Ambos bajorrelieves están trabajados en un lateral de los sillares y en ellos se aprecian las huellas de talla, es decir, el rebaje realizado para labrar los motivos una vez dispuesto el sillar en su posición en el edificio. De este modo, la parte del sillar en la que se labra el motivo se rehunde con respecto al paño de los restantes sillares del muro. Esto nos lleva a concluir que ambos bajorrelieves están tallados a posteriori y a diferencia de los de la fachada del nártex, no estarían concebidos inicialmente en la decoración del edificio. Por su disposición aleatoria, creemos que lo mismo sucedería con los otros dos bajorrelieves. Además, tendrían que haber sido grabados con anterioridad al revestimiento de los muros interiores del nártex, del que todavía se conservan pequeños fragmentos, sobre todo en la fachada E del aula.

\section{Placas decoradas}

Las placas de mármol decoradas que se localizaron durante las primeras intervenciones llevadas a cabo en el monumento se encuentran actualmente depositadas en el Museo Diocesano e Catedralicio de Lugo. Estas placas habían sido puestas en relación por varios autores con la decoración interior del monumento: «Lo bajo de los muros y la capilla irían revestidos de mármoles, correspondiendo a ellos los preciosos fragmentos que veremos después. [...] Esto mismo afianzan los fragmentos marmóreos, que son: dos de mármol sacaroideo; el uno, con dos delfines adosados por el buche y como brotando un surtidor de su hocico; el otro, con una corona de laurel ceñida a un disco radiado cóncavo y orla rectilínea de tallo ondeado con brotes de espirales y granadas alternando. Un segundo grupo, de mármol arenoso como el de las columnas, desarrolla en muy bajo relieve, ondulaciones provistas de hojas y rosetas, modeladas en superficies convexas, acreditando clasicismo, y aun hay otro fragmento pequeño, con algo de trenza y tallo hendidos, de apariencia menos antigua.» (Gómez Moreno, 1949: 421-423). Además de estos bajorrelieves que describe Gómez Moreno, señala Montenegro que durante la intervención de desescombro de 1927 se localizan «losetas de mármol con un grosor uniforme de 2,5 centímetros que apunta a una clara función de revestimiento.» (Id., 2005: 22).

Para el desarrollo de este trabajo nos propusimos revisar estas piezas con la intención de comprobar si tenían algún tipo de huella que nos permitiese vincularlas a las distintas zonas identificadas en el edificio donde parecía que había existido decoración de placas (el friso de los muros interiores del aula o el intradós de la bóveda del ábside). En total están depositadas en este museo 18 piezas.

Nos interesaba, por un lado, conocer el grosor de estas piezas, ya que, en el caso del friso, debían medir entre 6 y 9 $\mathrm{cm}$ de grosor, que es el que resta entre el mortero que se

Fig. 30. En la imagen superior se muestra un detalle del material de las placas, un mármol blanco. Este tipo

de mármol no se ha documentado en otras piezas gallegas ni tampoco se conoce ninguna cantera en la región de este material. Debajo, el rebaje circular de la
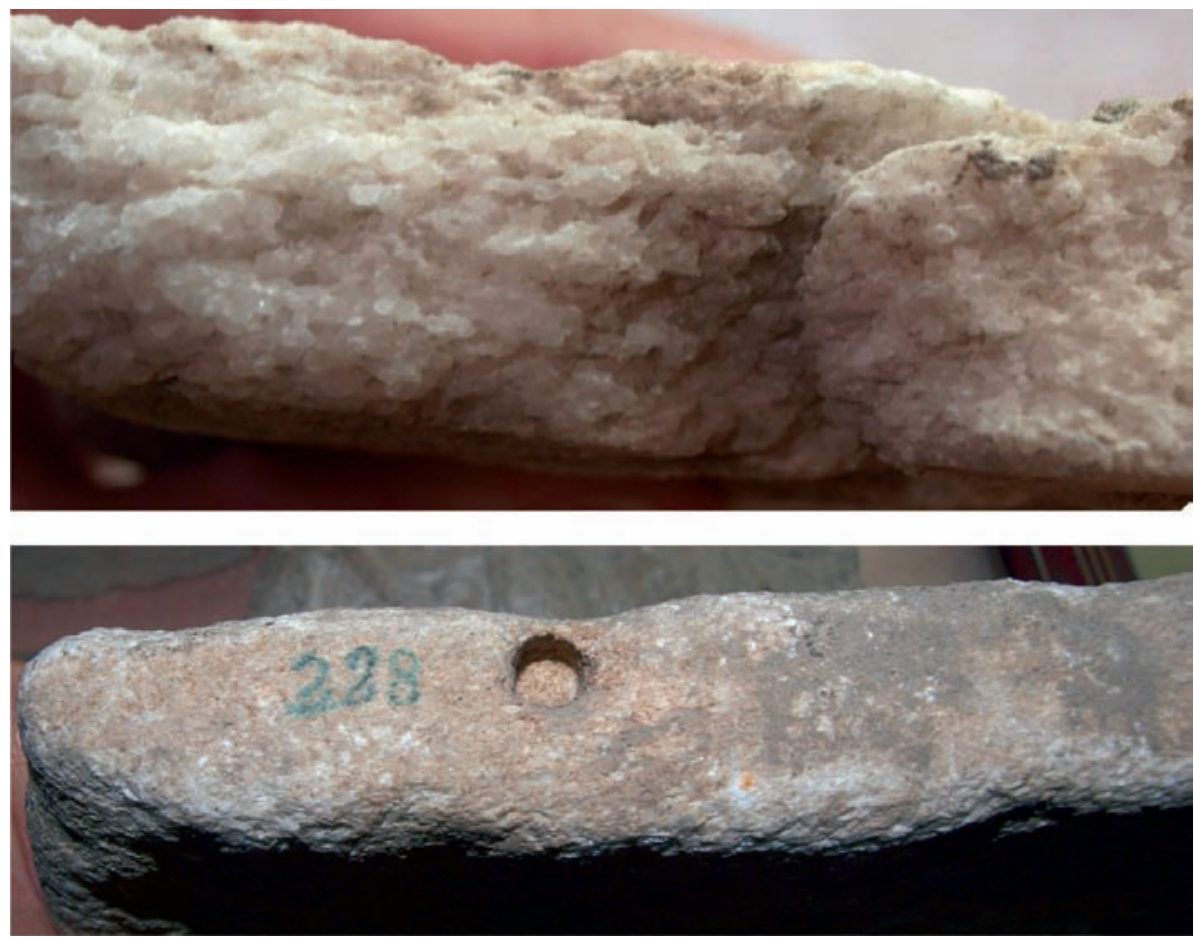

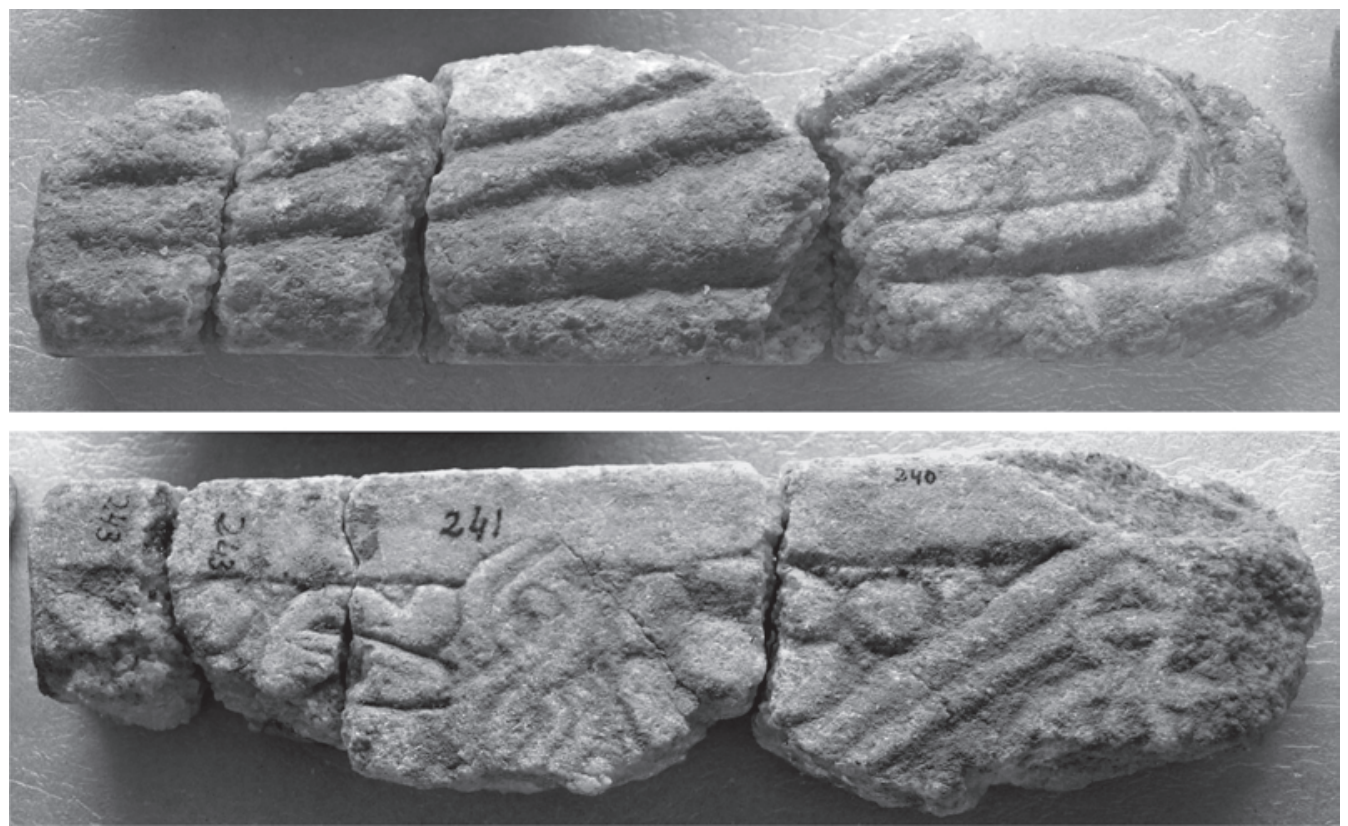

Fig. 31. Anverso y reverso de las piezas $236,238,239,240,241$ y 243 . Detalle del reverso

conserva con la impronta de las placas y la imposta de mármol. No sabemos, sin embargo, qué grosor tendrían las placas que cubrían la bóveda del ábside, pero teniendo en cuenta su posición, este debería ser menor que en el caso del friso. Por otro lado, nos interesaba también la presencia de rebajes en los bordes de las placas en los que encajasen las piezas de hierro que aún se conservan en los agujeros para los engarces de éstas. Debemos decir, que los resultados no son concluyentes, ya que la mayor parte de las placas están rotas y sus bordes muy erosionados y es difícil adscribirlas a alguna zona del edificio.

Con la excepción de una pieza de forma cuadrangular con rosetón inscrito de piedra caliza, todas las demás presentan similitudes en cuanto al material, un mármol muy blanco de cristales apreciables, como ya comentamos, de características similares al empleado en la imposta decorativa que se conserva in situ. En la imposta el material parece más oscuro, pero en el caso de las placas presentan fracturas recientes que permiten observar mejor el color así como su granulometría. Uno de los fragmentos conservados en el museo, concretamente la pieza con la sigla 235, podría formar parte de esta imposta por las similitudes que presenta con la que se conserva en el monumento.

De las restantes, únicamente el mármol con la representación del pez y la del rosetón, de un material diferente, alcanzan los $6 \mathrm{~cm}$ de grosor, mientras que las restantes oscilan entre los 2 y los $5,9 \mathrm{~cm}$. La mayoría presenta restos de mortero en el reverso, pero algunas también en el anverso, lo cual nos habla de una clara reutilización posterior.
En cuanto a las posibles huellas de engarces, únicamente se documenta con claridad en la pieza 228, que tiene un agujero de sección circular en el borde, que es indicativo de que estuvo colocada con la cara tallada en vertical.

Cabría pensar por los rebordes que tiene el mortero que se conserva in situ (ver en la figura 17 el mortero que se localiza entre la impronta de mármol superior y la impronta de las placas del friso), que el friso estuviera rehundido con respecto a las impostas y, en este caso, las placas podrían ser de un grosor menor que el que inicialmente habíamos pensado. Pero esto es, evidentemente, una hipótesis.

Nos detendremos únicamente en dos piezas. Por un lado la formada por los fragmentos 236, 238, 239, 240, 241 y 243, actualmente pegadas y expuestas formando parte de una pieza única. El anverso está decorado con motivos vegetales tallados a bisel, pero al darle al vuelta a la pieza nos hemos encontrado con que también estaba decorada, en este caso con motivos incisos más planos que representan un sogueado, una posible flor de lis y un motivo estrellado (figura 31). Todo apunta a la reutilización de esta placa ya que tanto los motivos como la técnica son diferentes en ambas caras de la pieza.

Por otra parte, estaría la pieza formada por los fragmentos 223 y 224 que encajan entre sí y que había sido descrita por Gómez-Moreno como «corona de laurel ceñida a un disco radiado cóncavo y orla rectilínea de tallo ondeado con brotes de espirales y granadas alternando", como apuntamos arriba. Llama la atención que bajo la 

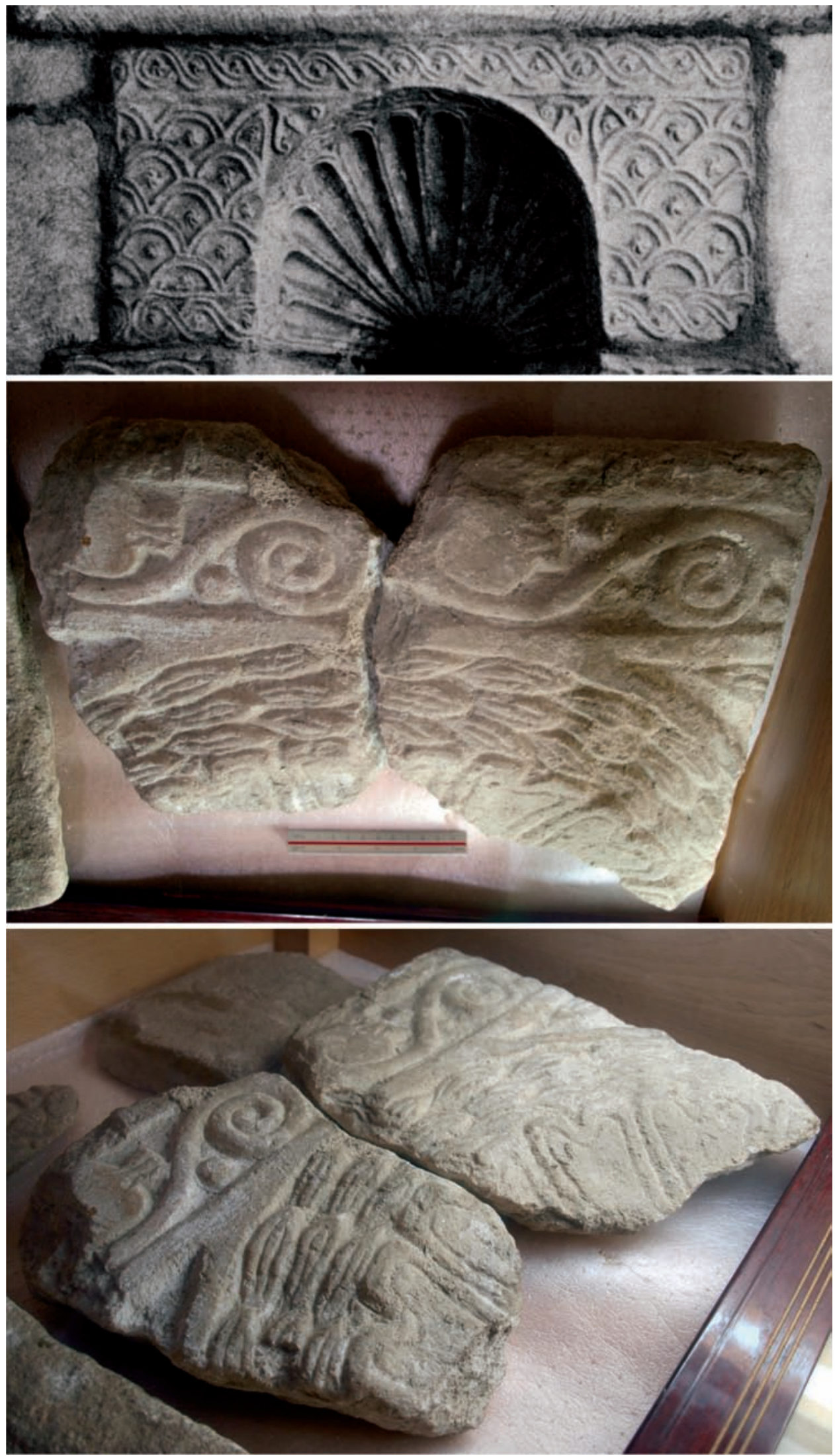

Fig. 32. En la imagen superior, arco que remata una ventana en Vera Cruz de Marmelar (Portugal), imagen extraída de Caballero y Arce (2007: 256-257). En las imágenes inferiores se muestran las dos piezas recuperadas en el desescombro de Santa Eulalia de Bóveda 
corona de laurel la pieza se rehunde a modo de arquito. Las piezas miden en total $53 \mathrm{~cm}$ de largo, 18 de alto máximo y el grosor oscila entre los 5,9 y los $3 \mathrm{~cm}$.

Los paralelos que hemos encontrado de piezas similares a la de Bóveda se localizan en arcos rematando ventanas, como en el caso de Vera Cruz de Marmelar (Portugal). Allí la pieza está reutilizada en la ventana y los autores presentan las dudas sobre si es esta del siglo VII o lo es el edificio en el que está reutilizada (Caballero y Arce, 2007: 256-257). En todo caso, parece que la funcionalidad de esta pieza, cuyas características difieren de las de las restantes piezas que se conservan en el museo, no tendría que ver con la decoración de placas del interior del edificio. En todo caso, si se trata del remate de una ventana, habría que ponerla en relación con el piso superior, ya que en la planta baja no tenemos vanos de estas características.

Finalmente, haremos una mención al único capitel de los conservados en el que todavía se pueden leer sus motivos. Se trata de un capitel corintio degenerado de dos filas de hojas lisas con un botón o flor esquematizada en el ábaco. Los paralelos que podemos encontrar en Lugo están también descontextualizados, como el capitel de San Xoán do Campo (Lugo) también de hojas lisas, cuya datación difiere según distintos autores que lo fechan entre el siglo IV y el x (Cabarcos, 2005). Otros paralelos podemos encontrarlos en Asturias, como en el caso del capitel de San Miguel de Teverga (Museo parroquial de San Pedro), con hojas nerviadas, cuya datación se atribuye probablemente al siglo IX (García de Castro Valdés, 2007: 86).

\section{Las pinturas del aula}

La gran difusión que ha tenido la decoración mural del aula hace innecesaria una descripción detallada ${ }^{26}$, por lo que nos limitaremos a hacer una breve definición y algunas observaciones.

De la parte superior de la bóveda no se conserva resto alguno in situ. Los grandes fragmentos caídos con restos de pintura los conocemos a través de antiguas fotografías y de los magníficos dibujos de Hanson ${ }^{27}$ y de Berenguer ${ }^{28}$. El esquema de la parte central de la bóveda consistía en octógonos formados por cuadrados flanqueados, a cada lado, por un hexágono de lados irregulares; dentro de cada

\footnotetext{
${ }^{26}$ Ver Abad Casal (1979 y 1982), Guardia (2003), Rodríguez Colmenero (1993) y Singul (1997 y 1998).

${ }^{27}$ Dibujo tomado de Montenegro et al 2008: 35.

${ }^{28}$ Schlunk y Berenguer (1991: 191). Precisamente en estos dibujos nos basamos para reconocer la situación de algunos fragmentos conservados en el Museo Provincial de Lugo.
}

figura se inscriben círculos y flores. Es un motivo ampliamente documentado desde época romana altoimperial, tomado de las decoraciones en mosaico ${ }^{29}$ y con repercusión en el arte visigótico y en el asturiano.

En la decoración conservada entre la imposta superior $^{30}$ de mármol y la zona de la bóveda perdida todos los registros están delimitados por una banda roja fileteada de negro y de una fina línea blanca; en la parte inferior esta banda es doble con un damero partido en el medio. Entre la imposta y el motivo descrito se desarrolla otro motivo geométrico muy erosionado, que probablemente consiste en una composición ortogonal de octógonos irregulares, secantes por los lados más cortos. A este motivo no se ha hecho referencia hasta el momento, al menos en las publicaciones consultadas.

En los muros laterales la decoración se organiza con una retícula en losange formada por flores vainiformes con los tallos entrelazados sobre un fondo claro ${ }^{31}$ con ramitas muy tenues y flores. Respecto a las ramitas, pensamos que lo que estamos viendo es el dibujo preparatorio realizado $a$ fresco con ocre y que las ramitas estarían pintadas a secco en color verde. Algunos detalles parciales nos permiten hacer esta observación (figura 36). Dentro de cada rombo o triángulo se representan siempre uno o dos racimos de uvas y un ave o dos, alguna vez en actitud de picotear el racimo.

Aunque las aves representadas no reproducen fielmente las características formales y posturales que permiten su identificación ${ }^{32}$, parece que el pintor tiene la clara intención de representar las diferencias de tamaño: mientras que los pavos reales llenan el espacio delimitado, incluso sobrepasándolo en algún caso, las tórtolas, palomas y perdices siempre están emparejadas y con amplio espacio alrededor, excepto en algunos triángulos en los que sólo aparece una figura.

El espacio triangular resultante entre la curva de la bóveda y los enjarjes se cubre con una gran planta en forma de sombrilla y a sus pies una pareja de aves: un gallo y una gallina u otra ave, los segundos picoteando la planta o las ramitas del fondo.

El intradós de los arcos que dividían el espacio inicial tiene un motivo frecuente también en un período dilatado,

\footnotetext{
${ }^{29}$ Barbet, 2003; V.V.A.A., 1985.

${ }^{30}$ Recordamos que la hipótesis que seguimos aquí es que el friso de placas que sirve de apoyo a las pinturas estaba enmarcado por dos impostas, de las cuales conservamos todavía in situ la superior.

${ }^{31}$ Probablemente el enlucido pulido. Más adelante incidiremos sobre la necesidad de análisis estratigráficos de la pintura.

32 Todas ellas son lo que hoy consideramos «aves de corral»: pavos, faisanes, tórtolas, perdices, codornices, ánade, gallos...; no obstante, las colas, las cabezas y las posturas de algunas no se ajustan a la realidad.
} 

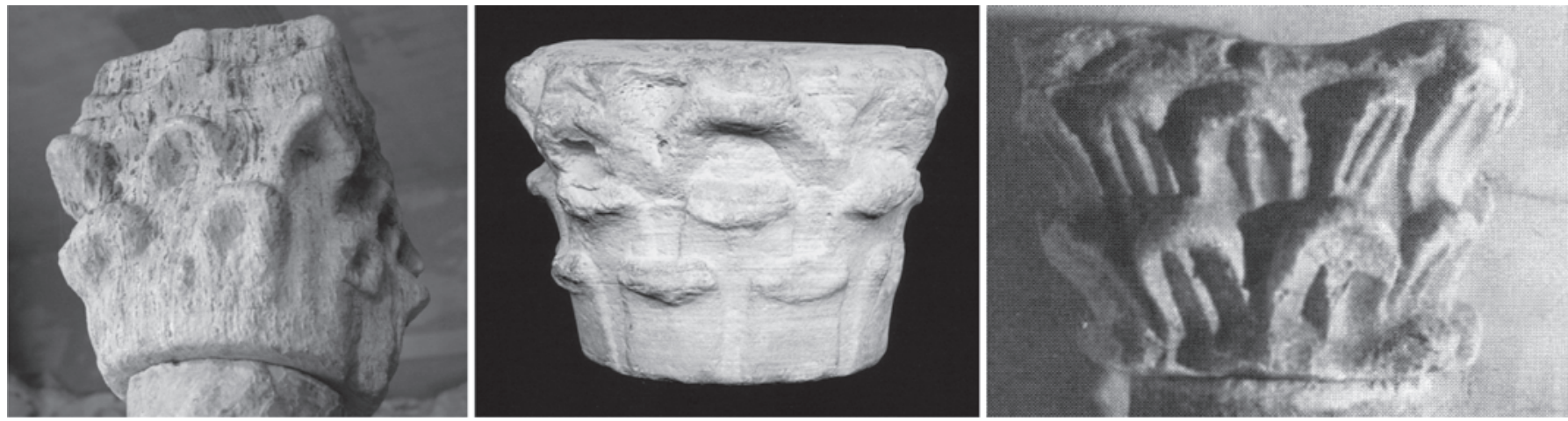

Fig. 33. Capiteles de Santa Eulalia de Bóveda, San Xoán do Campo, y de San Miguel de Teverga
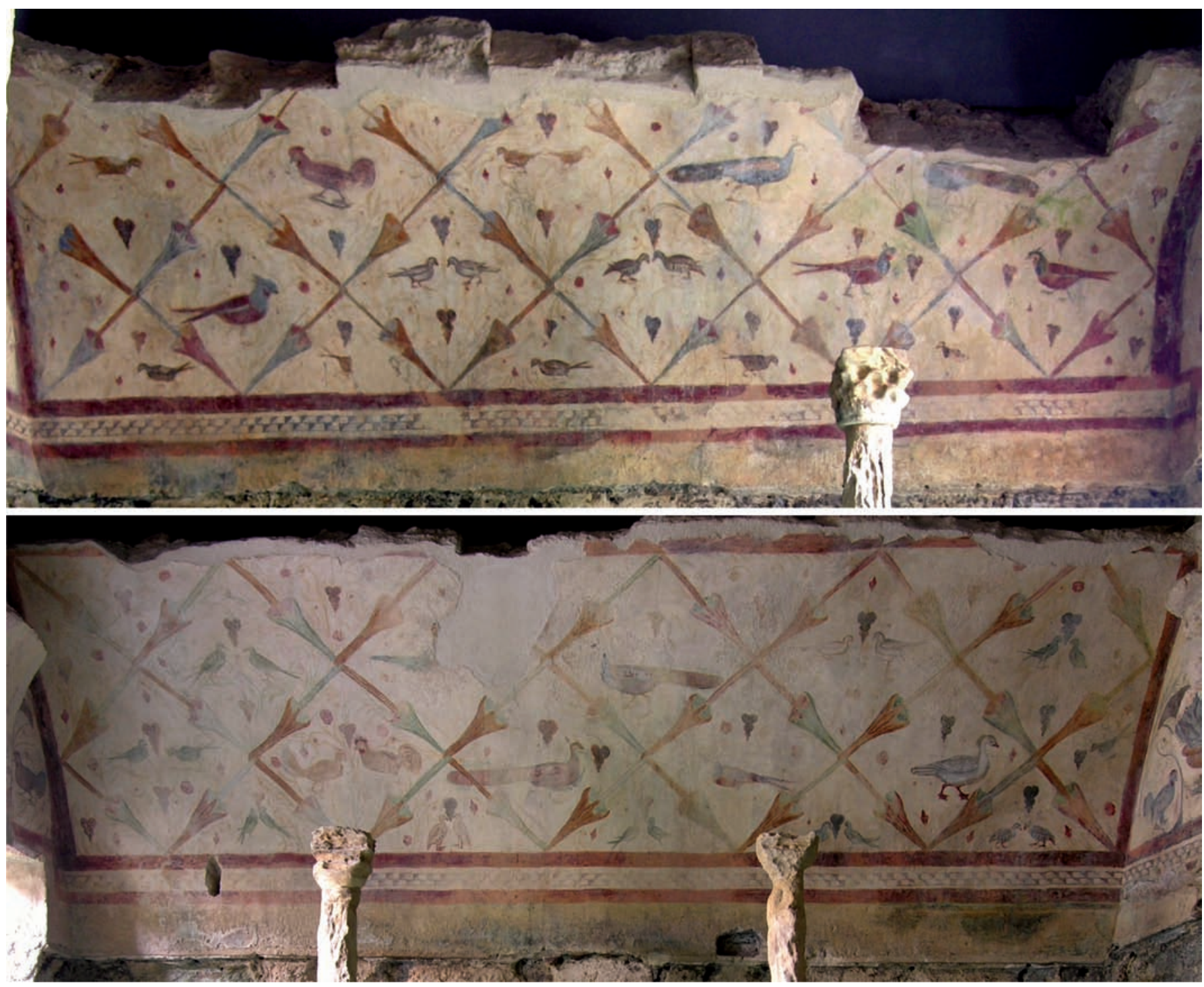

Fig. 34. Pinturas conservadas de la bóveda del aula: lados $\mathrm{N}$ y S

formado por un vaso del que sale una guirnalda de hojas verdes con flores (?) rojas y ramitas blancas, mientras que los alzados laterales se decoran con una secuencia de arquitos siguiendo la curvatura del arco y ramas y sobre estas, separadas por el encuentro de las bandas rojas, aves (ver figura 17). 


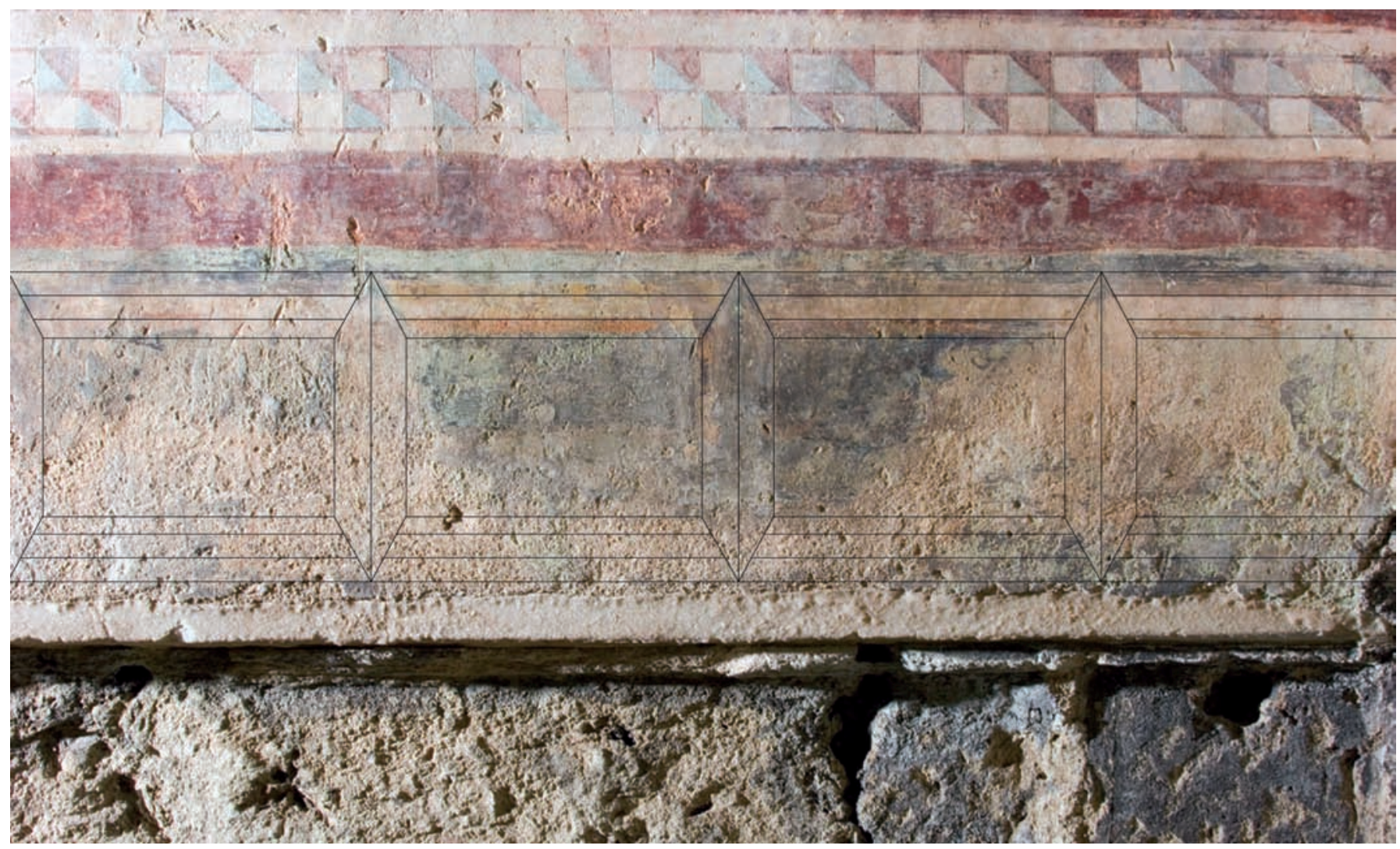

Fig. 35. Hipótesis de la composición ortogonal del arranque de la pintura mural de la bóveda

En la parte central de los hastiales los motivos son diferentes según la orientación. En el muro E, enmarcando la puerta de acceso al aula, se representa una guirnalda de flores saliendo de una gran flor; este motivo sólo se conserva en el lado $S$, aunque cuando se descubrió el edificio también se conservaba en el $\mathrm{N}^{33}$.

En el hastial W solo se conserva parte del extremo S; la decoración consiste en una imitación de mármol que, posiblemente, se completaba con aves, pues se pueden ver en el borde de fractura las patas y la cola, tal vez, de un pavo real.

En el zócalo se observan algunos restos de mortero de preparación bajo la primera imposta, aunque no anclajes, de lo que podemos deducir que probablemente estaba pintado.

\section{La preparación de las pinturas}

El soporte está constituido por varias capas de mortero cuyo número y espesor exactos no hemos podido determinar $^{34}$. En la parte accesible, sobre la imposta de mármol,

${ }^{33}$ Una imagen de este motivo perdido se puede ver en Montenegro (2005: 35, foto 23).

${ }^{34}$ Todos los bordes parecen estar protegidos por morteros de reposición. Aunque no se genera un borde continuo, el efecto visual y la penumbra del recinto este es variable según el muro y oscila entre los 7 y los $9 \mathrm{~cm}$, aunque parece que disminuye considerablemente a medida que asciende (figura 17). En esta parte inferior, está separado del muro por una línea de fragmentos inclinados de ladrillo o tegula ${ }^{35}$ (figura 17). La superficie tiene un acabado muy fino; sin embargo, se observan numerosas marcas de la herramienta de aplicación.

El análisis realizado por J.M. Cabrera en 1991 detecta capas con diferente granulometría ${ }^{36}$. En los más recientes

pueden llevar a confusión. De las intervenciones restauradoras que ha tenido el monumento no existen informes, ni siquiera de la más reciente, dirigida por Carmen del Valle, con lo que se perdieron oportunidades magníficas de documentar y difundir estos detalles constructivos.

${ }_{35}$ Para llevar el enlucido hasta la imposta de mármol. En el mundo romano es frecuente el uso de material latericio entre las capas de mortero, pero se hace con una intención diferente, la de aumentar la cohesión de las capas de mortero o la de aislar las habitaciones de la humedad. Se extiende en altura en todo el espacio que se quiere proteger y el resultado final del enlucido es aplomado.

36 «En los últimos $5 \mathrm{~cm}$ de mortero, más próximos a la superficie, distinguimos un fondo de agarre (cal y arena en proporción 1:2) sobre el cual se aplica otro mortero similar, más rico en cal, tirado con paleta, que correspondería al ARRICIO. En la superficie se aprecia una capa más fina y más rica en Cal, de enlucido, similar al INTONACO. En el mortero de agarre la cal y la arena están en proporción de 1:2, mientras que en la de ARRICIO la proporción aproximada es de 1:1. En el INTONACO la cal es más abundante 3:1 y se detectan partículas de CAOLÍN. Los granos de arena alcanzan tamaños de hasta $3 \mathrm{~mm}$ y los de Cal hasta 6 mm». (Cabrera Garrido, 1992:36). 
Fig. 36. Detalle de las ramitas verdes sobre el dibujo preparatorio ocre (extremo $\mathrm{E}$ del alzado $\mathrm{S}$ del aula)

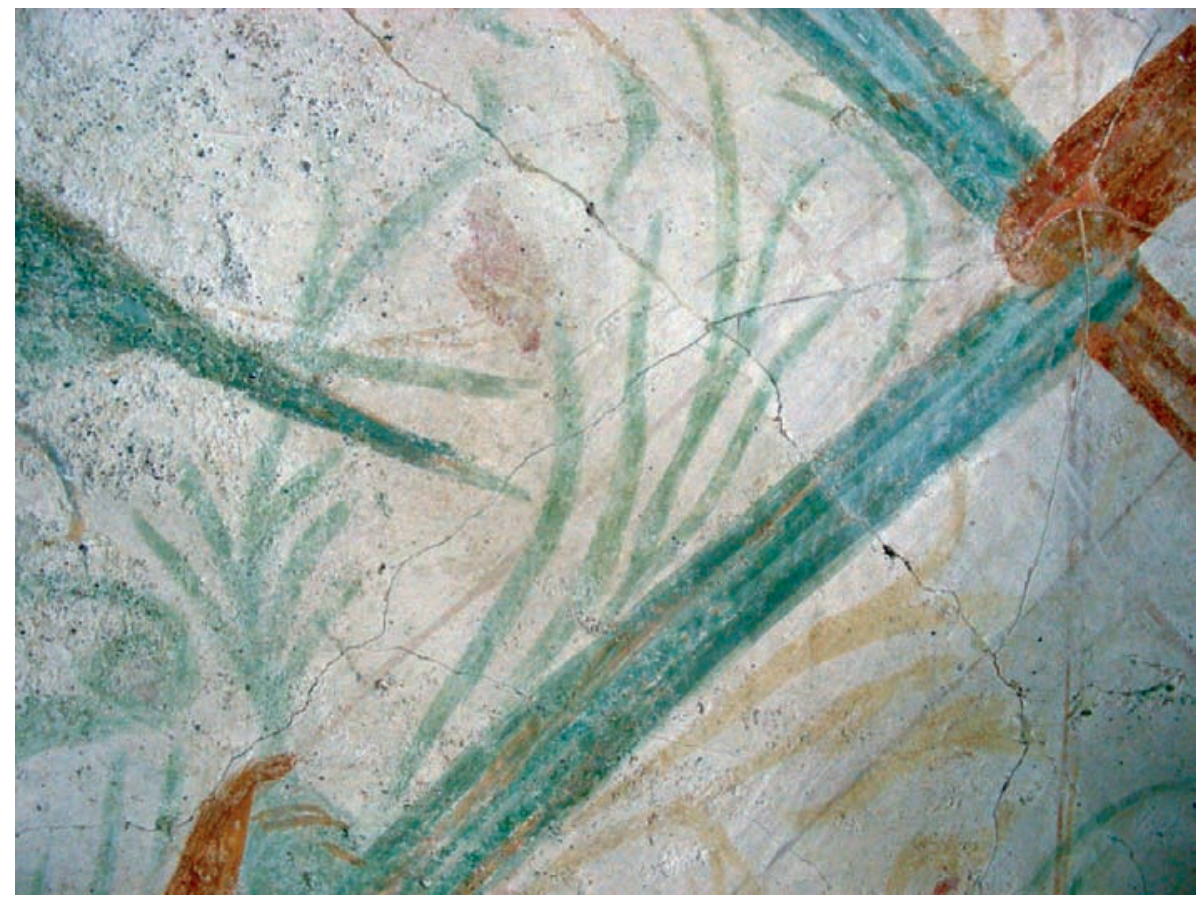

(2007), realizados con muestras muy pequeñas y superficiales parece que, al menos en los enjarjes, se utiliza el mismo mortero para juntas que para la preparación de la capa pictórica (arriccio e intonaco).

Vitrubio describe con todo detalle la fabricación de los enlucidos; aunque las siete capas de mortero que él recomienda o las cinco con que se conforma Plinio raramente se encuentran en la pintura mural romana que conocemos. Incluso Palladius ${ }^{37}$, a mediados del siglo V, sigue sus advertencias, pero es posible que con el paso del tiempo se pierda parte de la técnica y se unifiquen los morteros de las distintas capas de aplicación ${ }^{38}$.

En el análisis visual de los fragmentos de pintura parece que la naturaleza y la granulometría del árido es similar en las diferentes capas de aplicación (generalmente 3 en los fragmentos reconocidos); sólo se percibe una clarísima diferencia en la capa final de enlucido que parece componerse exclusivamente de cal, tal vez con árido finísimo de mármol o calcita que no podemos apreciar de visu. En este sentido ha sido muy útil revisar los fragmentos conservados en el Museo Provincial, rescatados por Felipe Arias en 1974 de la escombrera de las primeras excavaciones, sobre todo para documentar la pintura de la bóveda perdida de imitación de artesonado.

${ }^{37}$ Libro I, Tit. VIII-X.

${ }^{38}$ De hecho casi todas las pinturas pompeyanas analizadas cuentan con sólo tres capas. En la pintura fragmentada de la Domus Oceani de Lugo hemos llegado a reconocer hasta seis, aunque en la mayoría de los casos se documentan dos (Benavides, 2002: vol 1).
En algunos fragmentos, curiosamente, se ven áridos algo más gruesos en la capa anterior al enlucido y en otros, diminutos trozos de ladrillo en la capa más alejada ${ }^{39}$; lo último sucede casi siempre en los fragmentos que consideramos que podían formar parte de la bóveda perdida.

Los motivos decorativos están encajados entre líneas maestras en forma de cuadrícula, con incisión a punta seca o cordada realizadas con regla o tendel sobre el mortero fresco. De modo similar se traza un dibujo preparatorio para encajar las flores y tallos que forman los losanges, aplicado a fresco sobre el intonaco, con pincel y tierra ocre. También se encajan con dibujo preparatorio las figuras.

Respecto a la técnica pictórica empleada en Santa Eulalia se suele denominar como fresco. En la pintura romana que conocemos de otros yacimientos arqueológicos de Lugo siempre se documentan técnicas mixtas en las que se ejecutan a fresco una parte de la pintura y a secco, más o menos empastado, muchos de los detalles decorati-

\footnotetext{
${ }^{39}$ Esta adición de arcilla es frecuente en el mundo romano, Vitrubio la aconseja explícitamente en los enlucidos de parajes húmedos [VII, IV, 18]; estudios recientes demuestran que en el siglo $\mathrm{X}$ ya no es usual esta práctica: «Se observa que, en general, las estratigrafías de muestras de época romana tienen un mayor número de superposición de capas, con una esmerada selección de la arena en la preparación del soporte. Las primeras capas contienen cal y arena gruesa, las siguientes cal y arena fina y por último las que reciben los pigmentos junto a la cal. Destaca la presencia de arcilla en pequeñas cantidades en las muestras de este período.

Las estratigrafías de las muestras islámicas y modernas reducen el número de capas preparatorias, así como la granulometría de la arena empleada es más fina. En su composición mineralógica no se detecta la mezcla de arcillas identificadas en las romanas [...]». (Rovira Llorens, 2007: 698).
} 

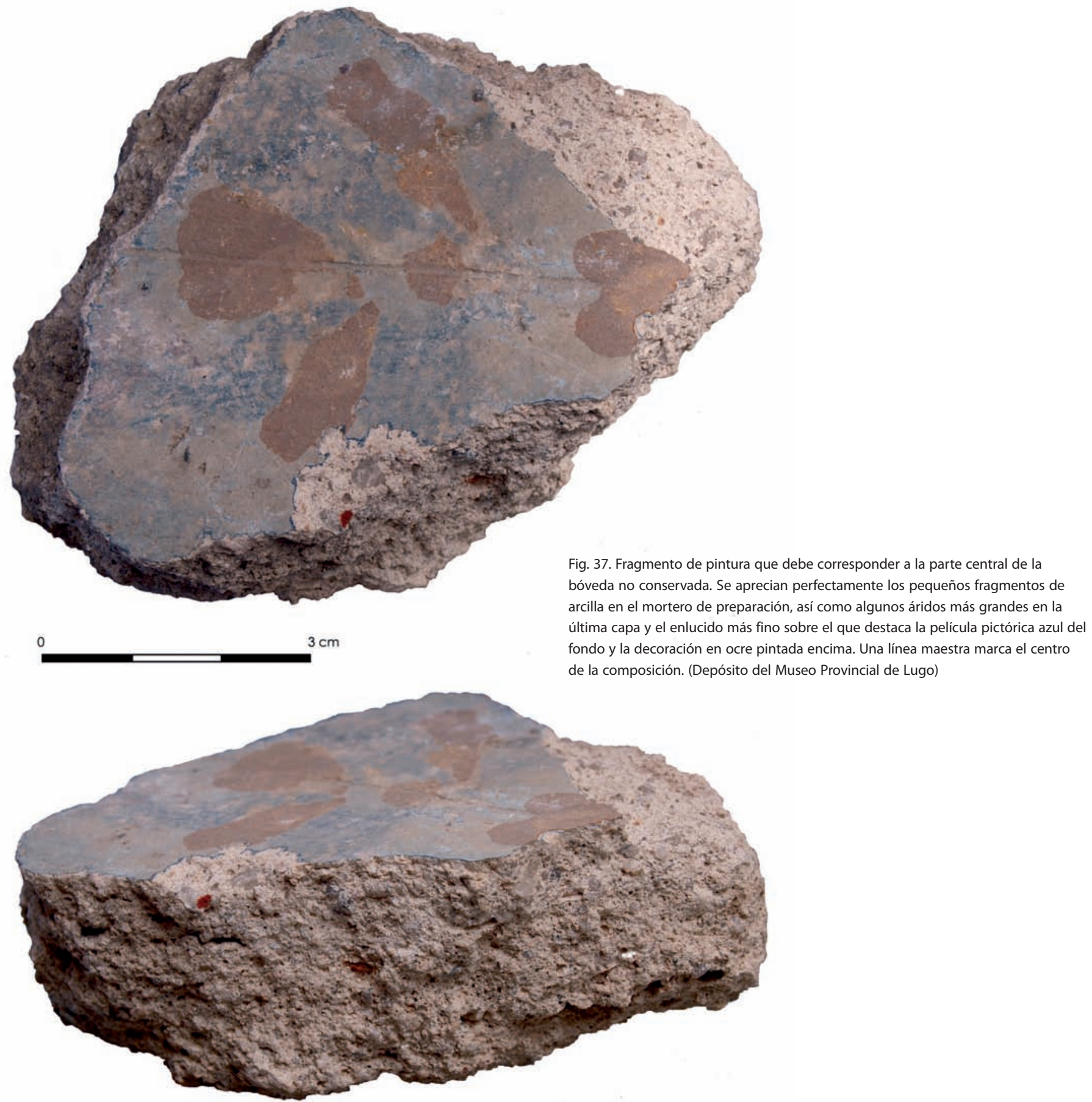

$\operatorname{vos}^{40}$. Algunos de estos detalles no son fáciles de observar in situ en Santa Eulalia; sin embargo, en los fragmentos conservados en el Museo Provincial se distinguen dos o tres capas de pintura ${ }^{41}$. Además, hay pigmentos que solo deben

${ }^{40}$ Es una percepción visual ya que aún no se realizaron análisis en este sentido y por tanto, nada podemos asegurar.

${ }^{41}$ Aunque no pasan del todo desapercibidos estos detalles en la pintura del monumento, lógicamente se perciben mejor al manipular los fragmentos, además de que éstos, aunque estén sucios y erosionados, no han recibido ningún tratamiento superficial. Se observa sobre todo en los rojos de los fondos aplicarse a secco, como el azul egipcio o la tierra de Verona, identificados por Cabrera, o el rosa. Las limpiezas realizadas en los primeros años tras su descubrimiento pudieron eliminar parte de estas capas de pintura ${ }^{42}$.

que suelen estar muy empastados, a veces son tan gruesos como la capa de enlucido. También suelen tener cierto relieve las bandas pintadas encima; sin embargo, los colores que se superponen para aportar matices son casi siempre muy sutiles.

42 «Es inolvidable la impresión que se recibía contemplando las pinturas del sector de bóveda descubierto primero, con toda la opulencia de colorido que 


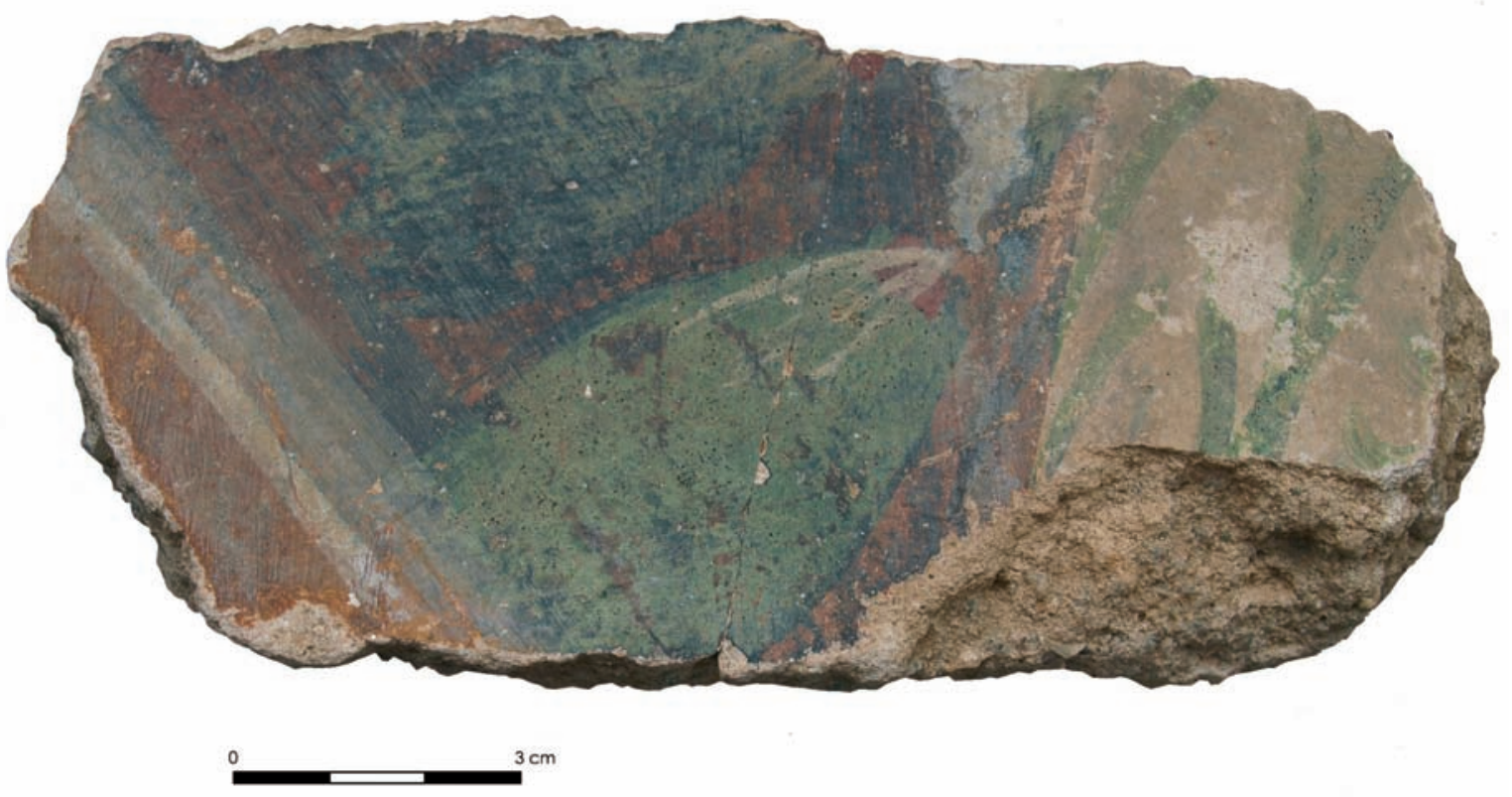

Fig. 38. Fragmento de pintura que debe corresponder a los enjarjes en el que se puede ver cómo los distintos matices de verde se consiguen por superposición de colores y cómo el rojo de las hojas está pintado sobre el verde y los trazos blancos sobre ambos. (Depósito del Museo Provincial de Lugo)

\section{Los pigmentos}

La paleta es relativamente amplia, no tanto en el número de pigmentos utilizados como en la gama que se consigue al mezclar o superponer colores y formada por distintas tonalidades de rojo, ocre, azul, verde, gris y rosa.

En Santa Eulalia, Cabrera identificó varios pigmen$\operatorname{tos}^{43}$ de uso común en el mundo romano, incluso uno de los considerados onerosos: el cinabrio ${ }^{44}$. Parece que, además de estos pigmentos, se utilizaron óxidos de hierro en los colores pardos y probablemente en los $\operatorname{rojos}^{45}$.

mantenía el ambiente húmedo del subterráneo. Luego, ya al aire libre, y a la intemperie durante más de un año que se tardó en protegerlas con un techo, se llenaron de verdines, cayó algún témpano de enlucido con ellas, sufrieron más aún al limpiarlas y aparecen hoy degradadas, secas sin los toques a temple que, sobre su técnica al fresco, las perfeccionaban.» (Gómez Moreno, 1949: 415416).

${ }^{43}$ El pigmento verde es «Tierra verde»; el negro «Carbón de Huesos»; el rojo "Cinabrio» y el blanco «Blanco de San Juan». El azul es azul egipcio sobre fondo negro (Cabrera Garrido, 1992: 37-46).

${ }^{44}$ Vitrubio lo llama también bermellón; los latinos lo llamaban minium y los griegos cinnabari.

${ }^{45}$ Aunque se detectó cinabrio en el rojo de la muestra analizada, pensamos que lo más probable es que se utilizase para los detalles y no para todas las cenefas que delimitan los registros decorativos. Debía ser un pigmento bastante caro a tenor de los comentarios de Vitrubio (VII, V, 29): «El aplauso que los antiguos solicitaban en sus obras á fuerza de habilidad, se busca ahora por los colores y su viveza: de forma que el mérito que las obras tenian por la destreza del artifice, se ha de conseguir ahora á costa del dueño. ¿Quién de los antiguos no gastó el bermellón tan parcamente como una medicina?».

\section{Fragmentos conservados en el Museo Provincial de Lugo}

De los ochenta y tres fragmentos inventariados, casi la mitad pueden adscribirse a la parte central de la bóveda que se perdió, doce corresponden a los enjarjes y cuatro al hastial de imitación de mármol; seis, que se parecen entre sí, no coinciden con los registros conservados in situ pero se pueden relacionar con un fragmento mayor descontextualizado ${ }^{46}$. Otros se pueden encajar en zonas diversas; solo uno de ellos parece no tener paralelo en el conjunto. En algunos se documentan líneas maestras (incisión) y jornadas.

Además de estos fragmentos, se conservan en el Museo otros cuatro descontextualizados, sin fecha ni lugar de procedencia. Uno de ellos podría proceder de Santa Eulalia; es un fragmento bastante grande que podemos situar perfectamente en una esquina del hexágono rojo de la bóveda perdida.

\footnotetext{
${ }^{46}$ Pensamos que podrían pertenecer a las zonas perdidas de la partición del aula, aunque en el desescombro se recogieron trozos de arcadas (Chamoso Lamas, 1952: 232), es aventurado pensar que pertenezcan a esta zona puesto que no quedan in situ más que los restos de los enjarjes y de los restos de arcadas desconocemos si existe alguna documentación y mucho menos su paradero. Por otra parte, si tenemos en cuenta que el edificio se colmató probablemente con tierra y escombros (quinientos metros cúbicos según el mismo autor) de los alrededores, es posible pensar que los trozos de pintura de los que no encontramos paralelos in situ procedan de otra edificación del entorno o del piso superior.
} 


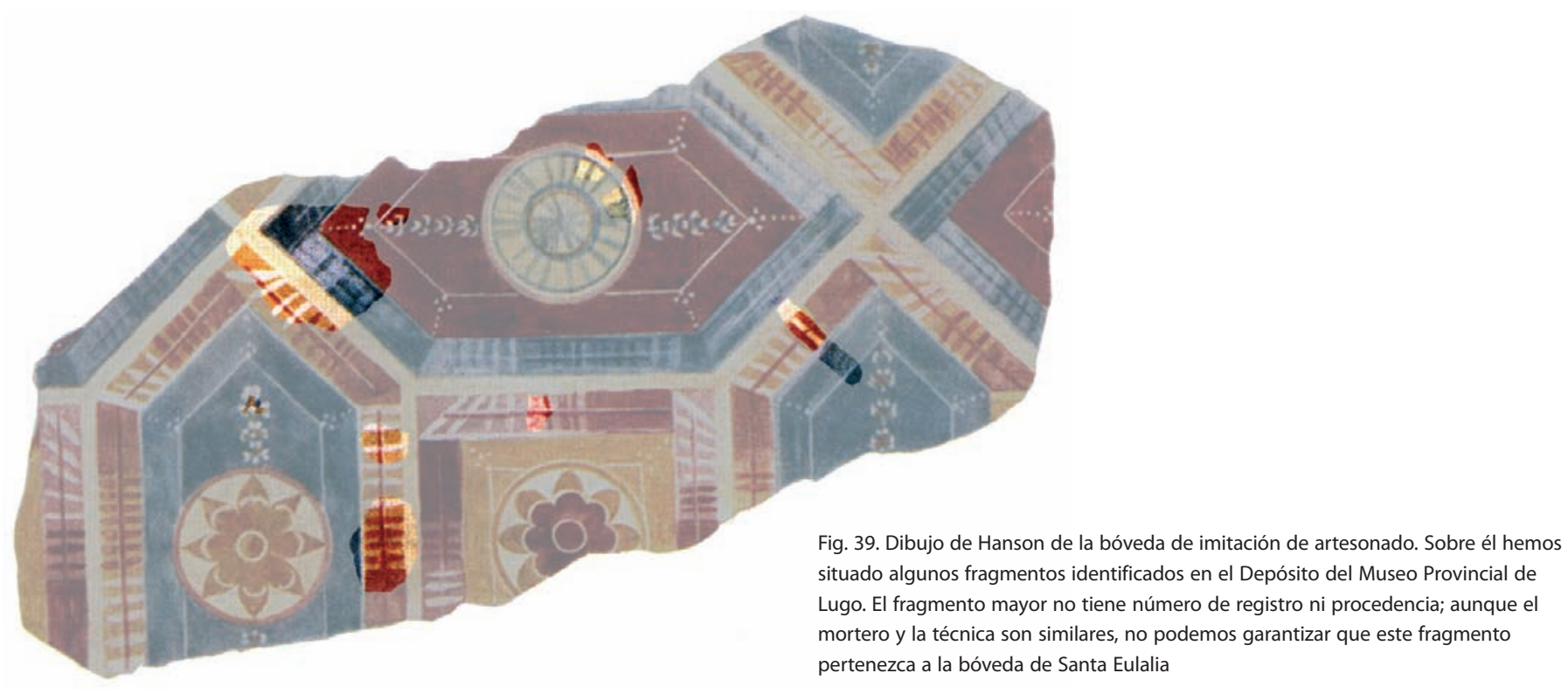

\section{ANÁLISIS DEL MATERIAL CONSTRUCTIVO DE SANTA EULALIA DE BÓVEDA}

\section{Lectura interpretativa de la caracterización de morteros de Santa Eulalia de Bóveda}

El trabajo conjunto entre los equipos de restauración y arqueología en la intervención de 2007 determinó la necesidad de caracterizar los morteros como apoyo del análisis estratigráfico. Teniendo en cuenta la evolución constructiva identificada a través de dicho análisis, se extrajeron muestras de mortero con distintas funcionalidades dentro del edificio, que se enviaron para su estudio a la Cátedra de Petrología de la E.T.S. de Ingenieros de Minas de Madrid, dirigida por J.M. García de Miguel.

Se analizaron catorce muestras, tres de ellas tomadas en UE vinculadas a la fase I, cuatro a la fase II, dos a la fase III, tres a la fase IV, una a la fase $\mathrm{V}^{47} \mathrm{y}$ otra en una UE indeterminada sobre la que existían bastantes dudas y que resulta ser un mortero confirmando los estudios realizados por Cabrera en 1992, como era la denominada «capa negra» que recubre algunas partes del monumento (el mortero analizado por Cabrera corresponde al recubrimiento documentado en la fachada del monumento, mientras que el analizado por García de Miguel se recoge sobre el mortero de sujeción de las placas de mármol en el alzado $S$ del aula).

\footnotetext{
${ }^{47}$ En este caso se tomó una muestra de mortero del que teníamos constancia que era de reposición (dato proporcionado por José López Fernández de la empresa constructora RESCONSA) para poder comparar los resultados con los de los morteros históricos.
}

Morteros vinculados a la fase I: las tres muestras presentan distintas características tanto petrológicas como químicas. El mortero 1 es diferente a los demás pues utiliza básicamente arcilla como aglomerante ${ }^{48}$. El 2 y el 3 pueden tener bastante en común; el hecho de que se detecte más o menos ligante puede deberse a que la muestra es demasiado pequeña y además disgregada. Ambos son morteros muy duros y difíciles de extraer.

Morteros vinculados a la fase II: al igual que en la fase anterior, los morteros presentan características petrológicas y químicas variables. El 4 y el 5a pueden ser, perfectamente, diferentes capas de una misma preparación. El $\mathbf{6}$ no podemos descartar que sea del mismo momento, cabe pensar que por cuestiones prácticas (para agilizar el fraguado, ya que tiene que soportar las losas de mármol) se le añadió yeso. También tiene yeso el 9, aunque no parece muy probable que se estén realizando al mismo tiempo el trasdosado de la bóveda del piso alto y la decoración con las placas de mármol entre impostas. El 7 es diferente a los de su fase, pero en la segunda fase es el único analizado con la función de junta (es frecuente el uso de calcita como árido, incluso en el mundo romano, para conseguir una granulometría más fina y una disminución de la porosidad). También tiene calcita como árido el $17 \mathbf{a}$.

Morteros vinculados a la fase III: los morteros analizados en esta fase poseen algunas características similares, ya que aunque varía la relación árido/aglomerante entre ellos, presentan semejanzas en cuanto a granulometría, propor-

${ }^{48}$ En edificios romanos de Lugo conviven los muros de juntas de arcilla con los de juntas de cal. 
ción cuarzo/feldespato y composición química ${ }^{49}$. Se parecen químicamente a los morteros 5 a y 6 de la fase II. El mortero 9 contiene yeso en el árido al igual que el 6 y la proporción cuarzo/feldespato es similar a la del mortero 5a. El 8 y el 9 parece que tienen similitudes suficientes entre sí como para poder considerarlos del mismo momento.

Morteros vinculados a la fase IV: los morteros 14 y 17 a guardan estrecha semejanza en cuanto a composición química y proporción cuarzo/feldespato y son similares en cuanto a las características del árido, pero no así el mortero 15. Además, el 14 y el 17a parecen tener ciertas similitudes con el mortero 7. Parece que no hay duda de que el 14 y el 17a pueden ser contemporáneos. El 15 es improbable que tenga que ver con el $\mathbf{2 b}$; la contaminación con cloruro de magnesio puede deberse a que se trata de una cal magra utilizada en las restauraciones de la época de Menéndez Pidal.

Mortero indeterminado: el mortero negro no podemos encuadrarlo en ninguna fase. Podríamos pensar que es posterior a la pérdida de las placas de mármol porque está recubriendo el mortero de sujeción de las placas y no se observa en su reverso ${ }^{50}$, pero también está recubriendo la cara inferior de las losas del suelo, como señala Cabrera (Cabrera Garrido, 1992: 15) ${ }^{51}$.

\section{Propuesta metodológica y limitaciones para la datación absoluta del monumento}

Uno de los objetivos finales del estudio realizado en Santa Eulalia de Bóveda era obtener la época de construcción del edificio original y de las distintas intervenciones realizadas en él a lo largo del tiempo.

Aunque en el proyecto inicial no estaba contemplado realizar análisis encaminados a la datación absoluta del monumento, las numerosas dudas que surgen del estudio, tanto de los elementos decorativos como de la propia arquitectura de Bóveda, nos llevan a plantear la necesidad de abrir una nueva vía de actuación, la cual todavía se encuentra en proceso de elaboración. Esta vía estaba prevista para una segunda fase de trabajo en el monumento que todavía no ha comenzado. Aún así, la colaboración

\footnotetext{
${ }^{49}$ En el caso de estos dos morteros, cabría la posibilidad de que ambos sean de reposición, lo cual contribuye a que las muestras coincidan. Por ello, volvemos a hacer hincapié en la necesidad de continuar efectuando análisis.

${ }^{50}$ La manganesa aporta hidraulicidad y tal vez por eso se emplea en un sitio tan húmedo. En el mundo romano se utiliza como pigmento pero para conseguir un mortero hidráulico se utilizaba puzolana o ladrillo. Vitrubio recomienda también cubrir con pez las tejas empleadas como aislamiento (Vitrubio VII, IV, 18-19). Aunque parece factible que los restos de placas ornamentales de mármol conservados en el Museo Catedralicio de Lugo procedan del edificio, no podemos asegurar que pertenezcan a la decoración entre impostas del aula.

${ }^{51}$ Sin embargo, no especifica en qué zona del suelo se documentó este mortero negro.
}

\begin{tabular}{|c|c|c|}
\hline Fase & Muestra & Resumen resultados \\
\hline \multirow[t]{3}{*}{ I } & $\begin{array}{l}\text { Mortero la (muestra supericial } \\
\text { de mortero de juntas de los } \\
\text { arcos fajones de la bóveda del } \\
\text { aula, alzado N) }\end{array}$ & $\begin{array}{l}\text { Es diferente a todos los demás estudiados ya que como aglomerante se emplea arcilla con } \\
\text { algo de cal; es de granulometria gruesa con elevada proporción de cuarzo. Relación } \\
\text { aglomerantéárioo 1:2. Porcosidad interparticula: 15\%. Contaminado con azuffe, fóstoro y } \\
\text { magnesio }\end{array}$ \\
\hline & $\begin{array}{l}\text { Mortero } 2 b \text { (muestra superficial } \\
\text { de de la zona interior del } \\
\text { arranque de la bóveda del aula, } \\
\text { alzado S) }\end{array}$ & $\begin{array}{l}\text { Es un mortero bastante singular porque es muy compacto y muy poco poroso a pesar de } \\
\text { ser muy pobre en cal. Relación aglomerante:arido } 1: 5 \text {. Porosidad interparticula: } 5 \% \text {. } \\
\text { Contaminado con cloro y magnesio. }\end{array}$ \\
\hline & $\begin{array}{l}\text { Mortero } 3 \text { (muestra supericial } \\
\text { de mortero de juntas de la } \\
\text { bóveda que cubre el espacio } \\
\text { del ábside; alzado E) }\end{array}$ & 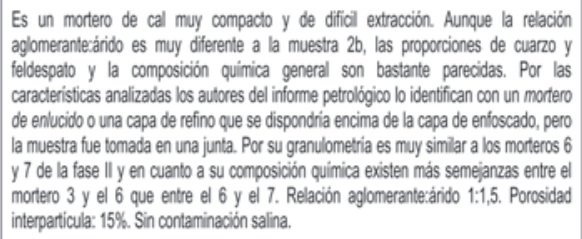 \\
\hline \multirow[t]{4}{*}{$\|$} & $\begin{array}{l}\text { Mortero } 4 \text { (muestra superficial } \\
\text { del mortero de juntas de un } \\
\text { resto de los enjaries que } \\
\text { separaban espacialmente el } \\
\text { aula; alzado W) }\end{array}$ & $\begin{array}{l}\text { Es un mottero muy rico en cal cuya composición quimica difiere del resto de los morteros } \\
\text { analizados dentro de esta fase constructiva. Por las caracteristicas analizadas su } \\
\text { funcionalidad es la de un montero de enlucioio con una proporción differente a la del } \\
\text { montero } 3 \text { de la fase I, aunque la muestra fue tomada en una junta. Relación } \\
\text { aglomeranteárído 1:1. Porosidad interparticula: } 15 \% \text {. Contaminado con azurfe, cloro y } \\
\text { magnesio. }\end{array}$ \\
\hline & $\begin{array}{l}\text { Mortero 5a (muestra supericial } \\
\text { de mortero de preparación de } \\
\text { las pinturas que recubren la } \\
\text { boveda del aula) }\end{array}$ & 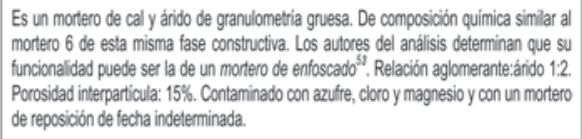 \\
\hline & $\begin{array}{l}\text { Mortero } 6 \text { (muestra del motero } \\
\text { de revestimiento de los alzados } \\
\text { inteniores del aula que } \\
\text { sopoctarian las placas de } \\
\text { mármol, azzado S) }\end{array}$ & $\begin{array}{l}\text { Es un mortero muy rico en aglomerante y es probable que además de cal contenga yeso } \\
\text { en su composición, añadido tal vez con la intenciön de acortar el tiempo de fraguado. En } \\
\text { cuanto a granulometria se parece al mortero } 3 \text { de la fase I y al } 4 \text { de la fase lla; sin } \\
\text { embargo, su composición quimica es muy similar a la del mortero } 5 \text { a. Relación } \\
\text { aglomerantéárido 1,5:1. Porosidad interparticula: } 20 \% \text {. Contaminado con magnesio, } \\
\text { fósioro y azufre (?). }\end{array}$ \\
\hline & $\begin{array}{l}\text { Mortero } 7 \text { (mortero de juntas } \\
\text { del arco de ladrilo que cubre la } \\
\text { puerta de access al aula) }\end{array}$ & $\begin{array}{l}\text { Es un mortero rico en cal, de granulometria fina y con una elevada proporción de calcita } \\
\text { como ánido (18\%). Debido a esta peculiandad en el árido su composición quimica no es } \\
\text { comparable a la de otros morteros de esta fase constructiva. Relación aglomerantéárido } \\
\text { 1,25:1. Porosidad interparticula: } 10 \% \text {. Sin contaminación salina. }\end{array}$ \\
\hline \multirow[t]{2}{*}{ III } & $\begin{array}{l}\text { Mortero } 8 \text { a (muestra de mottero } \\
\text { recogida en el interior de una } \\
\text { grieta de la bóveda de ladrillo } \\
\text { del alzado } \mathrm{N} \text { del piso alto) }\end{array}$ & $\begin{array}{l}\text { Es un mortero de cal de granulometria media-fina, con proporciones normales de } \\
\text { elementos comunes a otros monteros estudiados. Relación aglomeranteáarido } 1: 1,5 \text {. } \\
\text { Porosidad interparticula: } 20 \% \text {. Sin contaminación salina. }\end{array}$ \\
\hline & $\begin{array}{l}\text { Mortero } 9 \text { (muestra de mortero } \\
\text { de juntas del trasdis de } \\
\text { mamposteria de la bóveda de } \\
\text { ladillo del alzado } \mathrm{N} \text { del piso } \\
\text { alto) }\end{array}$ & $\begin{array}{l}\text { Es un mortero de cal, con árido de granulometria fina con algo de yeso (2\%). Guarda gran } \\
\text { similitud, respecto a las proporciones de los componentes quimicos con el montero } 8 \text { a. } \\
\text { Relación aglomerante:árido } 1: 3 \text {. Porosidad interparticula: } 15 \% \text {. Sin contaminación salina. }\end{array}$ \\
\hline \multirow[t]{3}{*}{ IV } & $\begin{array}{l}\text { Mortero } 14 \text { (muestra de mottero } \\
\text { de preparación con restos de } \\
\text { pelicula pictónica del } \\
\text { revestimiento de la boveda del } \\
\text { piso allo) }\end{array}$ & $\begin{array}{l}\text { Es un mottero de cal con alto contenido en calcio y con ánido de granulometria gruesa- } \\
\text { media. Se detecta un contenido elevado en hierro que seguramente procede del pigmento } \\
\text { utilzado en la pelicula pictónica. Su composicón quimica es de gran semejanza con el } \\
\text { montero } 17 \text { a. Relaciön aglomeranteárido } 1: 2,5 \text {. Porosidad interparticula: } 10 \% \text {. Sin } \\
\text { contaminación salina. }\end{array}$ \\
\hline & $\begin{array}{l}\text { Mortero } 15 \text { (muestra de mottero } \\
\text { de juntas de la reconstrucción } \\
\text { con mamposteria de la bóveda } \\
\text { del piso alto) }\end{array}$ & $\begin{array}{l}\text { Es un motero de cal con ánido de granulometria media. Su composición química es similar } \\
\text { a la del mortero } 2 \mathrm{~b} \text {, pero la proporción cuarzofieldespato y otras caracteristicas } \\
\text { granulométricas no coinciden. Relación aglomerante.ánido 1:2. Porosidad interparticula: } \\
\text { 10\%. Contaminado con cloruro de magnesio. }\end{array}$ \\
\hline & $\begin{array}{l}\text { Mortero } 17 \text { a (muestra de } \\
\text { mottero de preparación de las } \\
\text { pinturas del nártex) }\end{array}$ & $\begin{array}{l}\text { Es un motero de cal con alto contenido en calcio y ánido de granulometria media (contiene } \\
\text { un } 15 \% \text { de calcita como árido). Relación aglomeranteárido 1.2,5. Porosidad interparticula: } \\
10 \% \text {. Sin contaminación salina. }\end{array}$ \\
\hline ? & $\begin{array}{l}\text { Mortero CN-M (capa negra } \\
\text { extraida del alzado S del aula) }\end{array}$ & 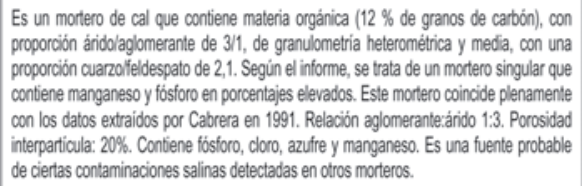 \\
\hline
\end{tabular}

Tabla 1. Resumen de los resultados de los análisis de los morteros

${ }^{52}$ Los resultados coinciden con el «arriccio» analizado por Cabrera (Cabrera Garrido, 1992: 36).

${ }^{53}$ Los resultados coinciden con el «mortero de agarre» analizado por Cabrera. Se trataría de la primera capa de preparación de la bóveda, según Vitrubio el mortero de «rectitud», con el que se crearía una superficie uniforme para regularizar la fábrica. 
entre los tres equipos mencionados al principio de este texto se ha puesto ya en marcha.

Una vez establecidas las fases de construcción mediante la lectura estratigráfica, se inició un trabajo de datación de diferentes materiales de construcción por medio de luminiscencia. Estos materiales son ladrillos de las fases constructivas I, II y III y morteros de todas las fases identificadas.

Los ladrillos son un tipo de material que suele ser datado por luminiscencia, utilizando metodologías estándar. Los morteros, sin embargo, son mucho mas problemáticos y la datación por luminiscencia presenta una serie de requisitos e inconvenientes. A pesar de ello, como se expone a continuación, es el único método que por el momento ofrece garantías a la hora de obtener una edad absoluta.

\section{Datación de morteros: métodos y limitaciones}

Los morteros son uno de los materiales de construcción mas utilizados desde tiempos muy antiguos (los ejemplos mas antiguos datan de unos $12 \mathrm{Ka}^{\mathrm{BP}}{ }^{54}$ ) y su estudio ha sido extenso en las últimas décadas ${ }^{55}$. El principal objetivo de estos estudios ha sido conocer su composición original y su datación. La composición suele ser variable dependiendo de los materiales originales (aglomerante y árido) y tanto el posterior proceso de curado como su deterioro (debido a humedad, polución atmosférica, etc.) con el tiempo constituyen un problema importante para conocer esa composición original.

La datación de morteros puede ayudar a conocer la época de construcción de muchos edificios históricos de edad no conocida y sus diferentes fases, ya que mientras en construcción ha sido frecuente la reutilización de diversos materiales como el ladrillo o la piedra, este hecho no es posible en el caso de los morteros, que deben constituirse en el momento de construcción de cada paramento. Por ello, el mortero es un elemento ideal de datación representativa de cada fase constructiva.

La datación de morteros ha sido abordada desde diferentes puntos de vista y aplicando diversas metodologías, pero hasta ahora solo han tenido un éxito parcial ${ }^{56}$. Además de la datación por luminiscencia, se han intentado otros procedimientos como la datación por radiocarbono del aglomerante o diversos métodos geoquímicos.

En el caso de los morteros de cal, la reacción del $\mathrm{Ca}(\mathrm{OH})_{2}$ con el $\mathrm{CO}_{2}$ atmosférico para formar $\left(\mathrm{CaCO}_{3}\right)$ durante el proceso de curado del mortero permite datarlo

\footnotetext{
${ }^{54}$ Elert et al., 2002: 62-75.

${ }^{55}$ Ver nota 55.

${ }^{56}$ Heinemeier et al., 1997: 487-495; Zacharias et al., 2002: 379-382; VendrellSaz et al., 1996: 143-149.
}

por ${ }^{14} \mathrm{C}$. Sin embargo, existen varios problemas bien conocidos debido al contenido previo del aglomerante en calcita, procedente de roca caliza, debido a la deficiente o incompleta calcinación de esta para formar el $\mathrm{Ca}(\mathrm{OH})_{2}$. Este hecho origina que se puedan obtener fácilmente edades más antiguas que la edad real del mortero. Además, otros problemas se deben al lento proceso de curado de algunos morteros poco porosos (que puede durar muchas década $\left.{ }^{57}\right)$ o a la recristalización debido a la disolución y reprecipitación del carbonato cálcico, incorporando carbono más moderno, lo que origina edades más recientes de la real.

La datación por métodos geoquímicos se basa en la comparación de las abundancias elementales entre morteros, cuando la edad de parte de ellos o de parte del edificio es conocida, aunque solo permite obtener edades relativas. El método se basa en el hecho de que el cation Ca de la estructura de la calcita puede ser parcialmente sustituido por otros elementos (como $\mathrm{Mg}, \mathrm{Fe}^{2+}, \mathrm{Sr}, \mathrm{Rb}$ y $\mathrm{Ba}$ ), dependiendo del ambiente. De esta forma, si el aglomerante calizo de dos morteros ha sido obtenido de rocas calizas con diferentes características geoquímicas, será posible diferenciarlos de acuerdo con la concentración de esos elementos minoritarios ${ }^{58}$. La limitada aplicación de esta técnica permite su uso solo en casos en los que existe documentación histórica del edificio o edificios estudiados y la cronología obtenida será solamente relativa.

\section{La datación de los materiales de construcción de Santa Eulalia por luminiscencia}

Los materiales arqueológicos y arquitectónicos pueden ser datados por Termoluminiscencia (TL) si los minerales que incorporan han sido calentados en el proceso de fabricación. En el caso de los ladrillos, la cocción sería el momento datado por la TL. Sin embargo, los minerales presentes en los morteros, al no haber sufrido un proceso de calentamiento, deben ser datados por Luminiscencia Estimulada Ópticamente (conocida por su acrónimo en inglés, OSL), de modo que el momento datado corresponde a aquel en el que los minerales de la arena han quedado ocultos o protegidos de la luz. Este momento se corresponde con el de colocación del mortero, como ya hemos comentado, por lo que permite datar el momento de fabricación de un paramento.

La edad obtenida por ambos métodos se puede calcular conociendo la paleodosis acumulada desde el momento de fabricación del material constructivo y la

\footnotetext{
${ }^{57}$ Ver nota 55.

${ }^{58}$ Vendrell-Saz et al., 1996:143-149.
} 
dosis anual de radiación ionizante que este recibe ${ }^{59}$. La radiación ambiental (alfa, beta y gamma) causa la creación de defectos en la red cristalina de los minerales datados, lo que da lugar a la deslocalización de electrones y su posterior almacenamiento en trampas de potencial estables. Estos electrones pueden ser liberados de esas trampas aplicando una energía adicional, provocando así su recombinación, lo que libera energía en forma de fotones (luminiscencia). La señal luminiscente es, por lo tanto, una función de la dosis absorbida, por lo que si la dosis ambiental es constante será una función dependiente del tiempo transcurrido desde su calentamiento (en ladrillos) o su exposición a la luz (en morteros).

En ambas técnicas, y sobre todo en la OSL, se ha producido en los últimos años una serie de avances y mejoras metodológicas que permiten obtener resultados cada vez más precisos ${ }^{60}$. Entre estos avances, los nuevos procedimientos de datación por OSL han permitido realizar las primeras tentativas de datar morteros con resultados desiguales pero prometedores ${ }^{61}$. Actualmente, la Unidad de Geocronología del Instituto Universitario de Xeoloxía Isidro Parga Pondal de la Universidad de A Coruña está trabajando en la mejora y desarrollo de esta técnica aplicada a morteros. En este sentido, el trabajo que se está realizando en Santa Eulalia de Bóveda representa un trabajo pionero para desarrollar los procedimientos que nos permitan datar estos materiales con la precisión requerida en el trabajo arqueológico.

Algunos de los trabajos de datación de morteros por OSL existentes en la literatura advierten de la existencia de problemas a la hora de calcular la paleodosis. Estos problemas se deberían a la incompleta o deficiente exposición de la arena a la luz durante la fabricación del mortero ${ }^{62}$. Sin embargo, los trabajos en curso muestran que este no es un inconveniente en los morteros muestreados en el edificio de Bóveda. Sin embargo, sí pueden existir complicaciones en el cálculo de la dosis anual debido a que es necesario tener en cuenta el material que rodea la muestra hasta unos $50 \mathrm{~cm}$ de radio, correspondiente al rango de penetración de la radiación gamma. Así, para el cálculo de la dosis anual debe considerarse la dosis de todos los elementos de un muro: morteros, ladrillo y/o piedra En medios heterogéneos, la modelización de esta esfera puede no ser lo suficientemente exacta como para rendir edades con la precisión que el trabajo arqueológico necesita.

\footnotetext{
${ }^{59}$ Aitken, 1985; Aitken, 1998.

${ }^{60}$ Murria y Wintle, 2000: 57-73 y Roberts, 1997: 819-892.

${ }^{61}$ Zacharias et al., 2002: 379-382 y Goedicke, 2003: 409-415.

${ }^{62}$ Ver nota 62
}

En Santa Eulalia los paramentos muestreados están construidos incorporando ladrillo, mortero y piedra. Además, el alto nivel de humedad puede tener un efecto importante en la composición elemental de los morteros. El flujo de agua puede cambiar la concentración de U, que aporta gran parte de la dosis anual, comprometiendo la exactitud de la datación. Por ello, se ha optado por calcular la dosis anual utilizando tres métodos diferentes que permitan obtener información acerca de las dosis de radiación totales y parciales de todos los materiales. De esta forma, se ha obtenido la composición de U, Th y K de los materiales que había que datar por medio de Análisis por Activación de Neutrones en las instalaciones de la Unidade de Ciências Radioquímicas e Radiofarmacéuticas del Instituto Tecnológico Nuclear de Portugal. Además, se ha medido la dosis gamma in situ, en cada punto muestreado por medio de un espectrómetro gamma portátil. Por último, en cada punto de muestreo se situarán durante unas semanas dosímetros cuya dosis será medida posteriormente por termoluminiscencia (TLD) para obtener la dosis gamma total que afecta a cada punto muestreado, proceso que todavía no ha tenido lugar.

\section{Resultados preliminares}

Las medidas preliminares (a partir del cuarzo extraído de cada muestra) por OSL y TL respectivamente de las paleodosis de los morteros y los ladrillos muestreados proporcionan unos resultados que permiten ser optimistas de cara a la obtención de la edad de cada fase constructiva del edificio. Las medidas de TL de los ladrillos permiten establecer dos grupos de paleodosis, uno entre 18,22 y 17,64 Grays (Gy) y otro entre 14,26 y 9,17 Gy. Acorde con lo esperado, las paleodosis de los ladrillos tomados en el piso inferior son similares entre sí y mayores que las del piso superior, lo que coincide con la hipótesis de que el piso superior corresponde a una fase de construcción más moderna.

El cálculo de la paleodosis de los morteros es algo más complejo, aunque los errores son menores que en el caso de la TL de los ladrillos. La representación gráfica en radial-plots ${ }^{63}$ e histogramas de las paleodosis de cada alícuota medida en cada muestra de mortero indica una elevada dispersión en algunas muestras y baja dispersión en otras. A pesar de estas diferencias, las paleodosis fueron calculadas por medio del Modelo de Edad Central (CAM) ${ }^{64}$ siguiendo las recomendaciones de la bibliografía ${ }^{65}$.

\footnotetext{
${ }^{63}$ Galbraith et al., 1999: 339-365.

${ }^{64}$ Nota 64.

${ }^{65}$ Goedicke, 2003: 409-415.
} 


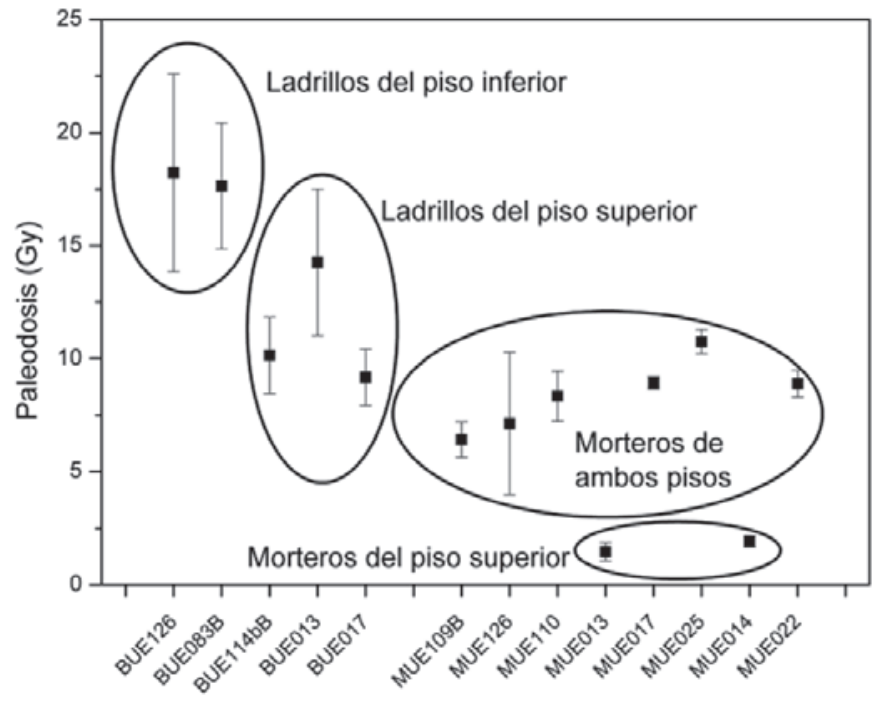

Fig. 40. Representación gráfica de la paleodosis (en Gy) medida en cada muestra. Tanto en los ladrillos como en los morteros se observan dos grupos diferenciados de muestras según su paleodosis

Las paleodosis obtenidas siguiendo este modelo muestran dos grupos de muestras diferenciados. Uno compuesto de morteros con una paleodosis pequeña $(1,46-1,92$ Gy), que corresponde a dos muestras del piso superior (MUE013 y MUE014), y otro compuesto por el resto de muestras medidas tanto en el piso superior como el inferior (MUE109; MUE126; MUE110; MUE017; MUE025: MUE022). Este último grupo comprende paleodosis de entre 6,42 y 10,75 Gy. El amplio intervalo de este grupo podría deberse a que los morteros corresponden a dos o más fases constructivas o bien a importantes diferencias en la dosis anual a la que están sometidas.

Uno de los factores fundamentales para la obtención de dataciones absolutas que permitan asignar un período histórico concreto para la construcción y las reformas del edificio es la desviación estándar en el cálculo de la paleodosis. Las desviaciones estándar obtenidas para la TL de los ladrillos oscilan entre el 24 y el 13\%, mientras que para los morteros oscilan entre el 13 y el $3 \%$, aunque para dos de las muestras son excesivamente elevadas (28 y $44 \%)$, lo que podría atribuirse a la dispersión de los datos y a las limitaciones del modelo de cálculo de la edad utilizado para casos en que la dispersión es precisamente elevada. Para mostrar la repercusión de la desviación estándar en el cálculo final de la edad se expone el siguiente ejemplo: supongamos que la edad absoluta real de uno de los materiales datados sea de 1000 años. Una desviación del $20 \%$ implica un error de \pm 200 años (es decir un intervalo de 400 años de edad), mientras que un error del $10 \%$ supondría \pm 100 años de error (un intervalo de 200 años) y uno del $5 \%$ serían \pm 50 años (un intervalo de 100 años). Dada la desviación estándar obtenida para las paleodosis, estos serían aproximadamente los porcentajes de error que se obtendrían para las edades de las muestras, suponiendo que la dosis anual se pudiese calcular con un error mínimo (1-2\%).

Esta circunstancia hace estrictamente necesario obtener un cálculo muy preciso de la dosis anual. Las mediciones preliminares realizadas de la dosis anual de cada muestra por medio de Análisis por Activación de Neutrones han permitido obtener una desviación estándar muy baja (en torno al $1 \%$ ), pero muy diferente a la obtenida con Espectrometría gamma in situ (con una desviación mucho mayor del 10-15\%). Los mayores problemas en el cálculo de la dosis anual, en este caso, se deben a la heterogeneidad de este medio, como se ha explicado ya anteriormente, ya que los muros están constituidos por sillares de roca, ladrillos y morteros de diferente composición. Aunque la dosis anual beta es independiente de este problema, el correcto cálculo de la dosis gamma (que suele suponer un $30 \%$ de la dosis anual ${ }^{66}$ ) depende por completo de elaborar un modelo adecuado o bien de utilizar un método alternativo. El método alternativo que se seguirá consiste en situar dosímetros de alúmina en los puntos muestreados durante un período de tiempo relativamente corto pero representativo (entre semanas y meses). Estos dosímetros acumulan una señal luminiscente debido a su interacción con la radiación gamma. Esta señal se mide posteriormente en el laboratorio por TL, con lo que se obtiene una dosis gamma más precisa que permite afinar el cálculo de la dosis anual y, por lo tanto, la edad final. Actualmente, se están realizando los trámites burocráticos pertinentes para situar los dosímetros en el edificio y obtener una edad final.

\section{CONCLUSIONES}

Si retomamos la imagen del capitel de San Xoán do Campo (Lugo) recogida en la figura 33, sobre ella se apunta en su ficha una adscripción cultural tardorromana o perrománica, del siglo IV al X. Gutiérrez Behemerid y Rodríguez Colmenero lo adscriben a época tardorromana, concretamente al siglo IV; Núñez Rodríguez a época visigoda, al igual que Varela Arias que lo ubica en el siglo VII; e Yzquierdo Perrín lo clasifica como un capitel prerrománico de los siglos IX-X. Lo interesante es el comentario que se expone a continuación: «Tal disparidad de dataciones corresponde a un hecho claro: la perduración de la

\footnotetext{
${ }^{66}$ Aitken, 1985
} 
tipología del capitel corintio en Galicia desde los tiempos tardorromanos (siglo IV) hasta el final del período perrománico, sometido a un proceso de esquematización, simplificación y desvirtuación de sus elementos característicos que en ningún modo fue lineal, sino que dependió de las tradiciones locales, de la mayor o menor pericia del artesano, de la dureza del material empleado o de la tendencia de ciertos tallistas a inspirarse en unos modelos tardorromanos que siguieron siendo considerados como un ideal» (Cabarcos, 2005). Este sería un problema similar al que se produce en Santa Eulalia de Bóveda, cuya arquitectura y decoración presentan similitudes con otros modelos del mundo romano y/o asturiano, abriéndose entre ambos un importante abanico de posibilidades del que se hicieron eco los distintos autores que trabajaron en el monumento.

Pongamos por caso el único de los tres capiteles conservados que se puede analizar formalmente, ya que el estado de conservación de los otros impide hacer una mínima descripción de su decoración. Los modelos más similares a este que hemos localizado son los de San Xoán do Campo que, como acabamos de ver, presenta una amplia cronología (del siglo IV al X) y el de San Miguel de Teverga ${ }^{67}$ que se adscribe, posiblemente, al siglo IX. Por otra parte, si añadimos lo ya comentado sobre la posición estratigráfica en la que los elementos fueron hallados, tampoco podemos asegurar la pertenencia de capiteles, basas y fustes de Santa Eulalia al edificio original del piso inferior.

El trabajo del que deriva este artículo tenía como objetivo principal la identificación de la secuencia constructiva del edificio; consideramos que este estudio está aún abierto a la espera de los resultados definitivos de las analíticas que se están llevando a cabo y que, sobre todo, se centran en obtener una cronologías absolutas que permitan datar esta secuencia. Como ya hemos comentado, a lo largo del siglo Xx el edificio ha sido sometido a importantes intervenciones que han afectado tanto al subsuelo del edificio como a sus muros, lo cual dificultó en gran medida la lectura del conjunto ya que, en muchas partes, la estratigrafía había sido cortada impidiendo observar las relaciones existentes entre las distintas partes del edificio. Del mismo modo, la importante presencia de morteros de recubrimiento, tanto históricos como de reposición, ha influido también negativamente en la lectura estratigráfica. No obstante, podemos inferir algunas conclusiones de los datos obtenidos.

\footnotetext{
${ }^{67}$ Que se conserva en el Museo Parroquial de San Pedro de Teverga (García de
} Castro, 2007: 86).
Un aspecto que nos perece interesante reseñar, que ha sido comentado en los apartados referidos a la arquitectura de Santa Eulalia, son las semejanzas y diferencias documentadas en las distintas técnicas empleadas en el edificio. Parece claro que aunque a lo largo del tiempo de uso de Santa Eulalia y en sus sucesivas reformas se utiliza de forma recurrente la combinación de la piedra y el ladrillo, sobre todo en los elementos de cubierta, el tipo de ladrillo y su uso varía en las tres fases iniciales.

Resulta notable, por ejemplo, el uso de ladrillos macizos en arcos y bóvedas de la planta baja con grosores variables, sin embargo, su disposición en obra varía entre los elementos identificados como de la fase I y la II. En el caso de la fase I en los arcos fajones de la bóveda cada ladrillo se separa el siguiente con una capa de mortero que mantiene el grosor en todo el ancho del ladrillo, creando una junta ancha, mientras que en los enjarjes de la fase II los ladrillos presentan una junta más fina en el intradós que en el trasdós creando así con el mortero la curvatura del arco. Lo mismo sucede en el arco de ligera herradura de la entrada. Además debemos recordar que mientras en el arco de la rosca de la bóveda del ábside los ladrillos del salmer y las primeras dovelas se disponen horizontalmente, en la puerta se disponen radialmente ya desde el salmer. Estas pequeñas diferencias, unidas a los cortes identificados para la disposición de los enjarjes nos llevan a separarlos en dos fases constructivas.

Sin embargo, se reserva para la planta alta el ladrillo de entalle que únicamente se documenta en esta bóveda y que, como hemos dicho, se viene considerando ladrillo romano reutilizado en una bóveda que la mayor parte de los autores sitúa en un momento posterior a la construcción original, aspecto con el que estamos de acuerdo. Lo cierto es que el empleo de ladrillo de entalle para fechas tardías y la manera de disponerlo en Santa Eulalia es inusual. Este ladrillo, como ya se apuntó, se emplearía en la construcción de arcos fajones en bóvedas romanas. Este es uno de los motivos que ha llevado a plantear la reutilización de material romano en una bóveda que con seguridad es posterior a la fase original del edificio. Hemos manifestado anteriormente (Benavides y Blanco-Rotea, 2008: 61) nuestras dudas con respecto a esta reutilización. Los ladrillos que hemos podido observar in situ y los que se encuentran depositados en el centro de recepción de visitantes del monumento están prácticamente todos ellos enteros. Para cubrir una bóveda de estas dimensiones sería necesaria una cantidad de ladrillos importante, mucho mayor que el que se emplearía en unos arcos fajones embebidos en la bóveda, es decir, si toda la bóveda se realiza a base de ladrillos de 
entalle sería necesaria la reutilización de ladrillos provenientes de varias bóvedas. En este sentido nos planteamos varias posibilidades, la reutilización de ladrillo de entalle de una bóveda romana y la copia de este tipo de ladrillo en un momento posterior en el que además se emplea siguiendo una técnica constructiva totalmente diferente a la de su uso original. Esta hipótesis podría apoyar la planteada más arriba sobre la existencia de dos pisos desde la primera fase del edificio. En todo caso, aunque no resulte del todo lógico, cabría preguntarse, si se podría estar copiando un modelo de ladrillo formalmente romano en un momento posterior, mientras que no se mantiene su uso original puesto que puede haber perdido la tradición constructiva que posibilitaría su correcto uso.

Si a todo ello sumamos los resultados de las paleodosis de las muestras analizadas en ambos pisos, claramente nos encontramos ante dos grupos distintos de ladrillos y morteros.

En cuanto a la tipología de la planta del edificio, no existe un modelo similar en Galicia que permita buscar paralelos claramente definidos con los que poder comparar Santa Eulalia. De hecho, los edificios gallegos altomedievales que han sido estudiados mediante un análisis arqueológico, Santa Comba de Bande fechada en el siglo IX (Caballero et al., 2004) y San Martín de Prado, cuya primera fase se vincula al perrománico (Feijoo y Rúa 1995), no presentan similitudes en muchos aspectos con Santa Eulalia, y desde luego la planta difiere bastante de ambos.

Con respecto al arco de herradura de la entrada al aula, algunos autores lo señalan como el origen de este tipo de arco en la Península: «Si aceptamos las cronologías tradicionales de estos edificios, el dintel con arco de descarga, tendría su origen en época tardorromana (Bóveda) y perviviría en la visigoda (Nazaré y Trampal) y mozárabe (Melque y Lourosa). [...]

En Santa Eulalia de Bóveda, el arco de ladrillo de la entrada única occidental descargaría sobre un dintel de piedra, del que sólo se conservarían los extremos empotrados ahora como impostas. Tanto Camps (1953: 61) como Fontaine (1978: 99), el primero bajo influencias sirias, ven en este ejemplo el primero de los posteriores. Aunque en un principio se aceptó la fecha del siglo IV, en la actualidad las hipótesis cronológicas son múltiples, habiendo indicios para sugerir una fecha altomedieval de este y otros elementos de Santa Eulalia» (Utrero, 2006: 65-66).

Como hemos visto, la pintura del aula responde a la decoración mural derivada de la remodelación del edificio, con la división del espacio inferior. Aunque aceptemos la hipótesis más difundida sobre el origen tardorromano del edificio, es difícil seguir encuadrando la pintura en este momento. Creemos que esta circunstancia, lejos de ser negativa, abre una puerta hacia el conocimiento de la construcción después de Roma.

Las técnicas constructivas romanas tuvieron una difusión enorme debido a la expansión del Imperio por un vasto territorio y no es raro pensar que hayan perdurado casi intactas varios siglos tras la «desaparición» del mundo romano. Las recomendaciones de Vitrubio las secundan autores muy posteriores a él ${ }^{68}$; incluso hoy siguen siendo tremendamente útiles tanto para conocer la construcción romana como para trabajar con materiales tradicionales.

Por lo que conocemos de la pintura de Santa Eulalia, la técnica de ejecución, los colores y los motivos mantienen la tradición romana. $\mathrm{Si}$, como parece, su ejecución fue más tardía, el hecho se explicaría perfectamente porque se trataba de una técnica eficaz y duradera y que con el paso del tiempo sólo fue preciso adaptarla a las nuevas corrientes ideológicas con la introducción, tal vez, de ciertos elementos simbólicos que en el caso de esta pintura no parecen tan claros, puesto que han originado casi tantas interpretaciones como autores han escrito sobre ella.

Esta pintura parece alejarse de la asturiana en la que casi todos los autores apuntan que están reflejadas. Aunque con semejanzas en los motivos decorativos, se diferencian en la preparación de los muros, con morteros extraordinariamente ricos en cal y una paleta menos colorida (con la ausencia de bermellón y azul egipcio tan característicos de la época romana) que en Santa Eulalia de Bóveda; no obstante, los análisis de la pintura asturiana tampoco han sido exhaustivos ${ }^{69}$.

${ }^{68}$ Como bien dicen las reconocidas especialistas en pintura mural antigua, Claudine Allag y Alix Barbet, será muy difícil establecer una cronología de las pinturas murales basándonos en el análisis de los morteros debido a la perduración de las técnicas constructivas romanas: "Ces quelques indications pratiques, valables à l'époque oú Vitruve écrivait sont-elles suffisantes, n'y a-t-il pase eu d'autres procédes? Quels quils soient, sont-ils un héritage du passé, dérivé de techniques grecques? et ontils duré longtemps?

Sur ce dernier point, nous possédons un autre témoignage littéraire, du milieu du $V^{e} s$. ap. J.-C., c'est celui de Palladius, qui dans le De re rustica, donne quelques conseils pour le choix du sable et de la chaux por confectionner des mortiers. Malheureseument ces conseils sont assez peu nombreux pour nous en apprendre davantage que Vitruve, ils sont assez semblables à ceux de l'auteur du de Architectura: la permanence des techniques de la maçonnerie est nette et il peut sembler vain d'entreprendre une étude des mortiers, avec l'espoir qu'elle se révèle utilizable pour différencier des époques». (Allag y Barbet, 1972: 938).

69 «En la iglesia de Santullano las diversas capas de enlucido (tectorium) están reducidas a dos: la trullisatio y el intonaco. La trullisatio representa la primera mano de revoco extendida sobre el muro humedecido para sacar la «rectitud» a la pared. Se compone de cal y arenato. En la iglesia de Santullano esta primera capa, variable entre $2,5 \mathrm{~cm}$ y $3 \mathrm{~cm}$ de espesor, tiene una composición de un 30 por 100 de arena y un 70 por 100 de cal. A continuación de la trullisatio, se extendió una capa de $0,5 \mathrm{~cm}$ a $1 \mathrm{~cm}$, aproximadamente, de espesor, llamada intonaco, compuesta de arena muy fina y polvos de mármol y cal en proporciones 
En defensa de la «romanidad» de la pintura de Santa Eulalia podemos decir que su ejecución es similar a otras que conocemos de cronología romana bajoimperial. Hoy la pintura conservada parece algo plana porque tiene lagunas, está parcialmente erosionada y perdió una parte, probablemente importante, de los motivos ejecutados a secco que aportaban volumen y profundidad. Observando los motivos geométricos de la bóveda perdida y de las decoraciones sobre la imposta vemos que están pintados para ofrecer este efecto visual de profundidad. En la bóveda, el perímetro de los cuadrados y hexágonos está pintado en degradación de $\operatorname{color}^{70}$, de modo que produciría el efecto de un artesonado ${ }^{71}$; esto se observa también en el motivo infinito sobre la imposta, en el que en las bandas que cierran el casetón se emplea un color más luminoso en la parte central y más oscuro en los exteriores y el fondo del casetón es todavía más oscuro. El efecto visual debía de ser parecido al de la bóveda. Incluso el damero partido debía de ofrecer sensación de perspectiva.

En la decoración de flores y aves, los distintos matices, obtenidos muchas veces por superposición de colores y la delicadeza de algunos acabados, indican una maestría notable, independientemente de la fidelidad o realismo de las representaciones. Tal vez el pintor está pintando de memoria una representación conocida, pero no sobre un modelo directo, y se basa en sus propias vivencias para representar las aves o plantas ${ }^{72}$.

iguales. Sobre ella se aplicaron, ya definitivamente, los colores desleídos en agua» (Arias, 1992).

«En la pintura mural de la iglesia de Santullano se han empleado varios pigmentos colorantes, en cuya composición se pueden identificar los siguientes materiales: blanco, integrado por caliza y cuarzo; rojo, óxidos hidratados de hierro; amarillos, óxidos de hierro; negro, madera carbonizada.

El empleo de estos pigmentos de forma generalizada en la pintura mural de otras iglesias asturianas no se puede confirmar al carecer de estudios técnicos precisos en la totalidad de las mismas [...] De acuerdo con los estudios realizados por Jesús María Puras la composición de los pigmentos de los frescos de Valdediós quedaría resumida en los siguientes datos:

Habitualmente la pared se colorearía con óxido férrico para dar un tono blanco crema más cálido. Amarillo y ocre claro, integrado por almagre, óxido de hierro hidratado y silicato de aluminio; rojo, óxido de hierro anhidro; verde, óxido férrico y ferroso; azul grisáceo o negro azulado, calcinación de materias orgánicas y probablemente de la combustión de huesos animales o maderas muy densas como encina, boj..." (Arias, 1999: 61).

${ }^{70}$ La degradación de color se refuerza con pinceladas transversales a modo de veladuras; este mismo sistema lo emplea el pintor para dar volumen a la secuencia de arquitos de los laterales de los enjarjes.

${ }^{71}$ En Santullano, que es el paralelo más utilizado, como apunta M. Guardia (2003: p.276), parece que la imitación de artesonado está copiada de un mosaico y probablemente el efecto de profundidad es menos patente que en la imitación de artesonado de Santa Eulalia.

${ }^{72}$ No es un hecho inusual; mientras que las ilustraciones del Dioscórides de Viena (Cruz, 2007: 229) son muy realistas, no sucede lo mismo con las del magnífico ambón donado por el obispo Agnellos a la Catedral de Rávena (Palol y Ripoll, 1988: 33); ambas representaciones están fechadas en el siglo VI.
Es obvio que no se conoce un paralelo exacto a las pinturas de Bóveda, aunque existen numerosos paralelos parciales; es decir, edificios diversos con decoraciones pictóricas que representan motivos similares. Precisamente, el hecho de que los diversos motivos representados en Santa Eulalia aparezcan en edificios de diferente funcionalidad y cronología hace que nos encontremos ante un monumento bastante singular.

El esquema de decoración de la bóveda está ampliamente documentado en un período muy amplio tanto en mosaico como en pintura ${ }^{73}$. Del mismo modo aparecen representadas las retículas ${ }^{74}$, los jarrones, las flores, las aves y las uvas y por supuesto las imitaciones de mármoles.

Las flores y los frutos representaban para los romanos un símbolo de inmortalidad por el constante morir y renacer $^{75}$. Las aves también son un tema frecuente en el mundo funerario ${ }^{76}$; los pavos afrontados con un vaso en el medio tienen un amplio uso en el ámbito cristiano en el

${ }^{73}$ Los esquemas repetitivos combinando formas geométricas adornadas con figuras vegetales estilizadas son frecuentes en las decoraciones de las bóvedas pintadas como en la casa de Polibio en Pompeya (Croisille, 2005: 74), en el hipogeo de Via Dino Compagni (Tortorella, 2004: 108-109) y en las revestidas de mosaico como las de los Mausoleos de Gala Placidia y de Santa Constanza (Barral, 2003: 37 y 82-83; Collins, 2007: 66), en las que también aparecen las decoraciones de los intradoses de los arcos con ramos, sin olvidar en la segunda las representaciones de aves, flores y frutas; eso sí, junto a numerosas representaciones humanas de las que en Galicia no tenemos ejemplos en épocas tan tempranas.

Aunque con menos pericia, se representan en los alzados de la «basílica» de Troia, en Portugal, la composición geométrica de la bóveda, la banda de pequeños cuadrados alternantes divididos diagonalmente, las imitaciones de mármol y los jarrones. Nunes Pedroso encuadra esta pintura en el siglo IV d. C. (Id., 1998 y 2006).

${ }^{74}$ Respecto a la retícula de Santa Eulalia de Bóveda, Abad Casal hace una reflexión interesante: «Santa Eulalia de Bóveda pertenece a un momento muy evolucionado de la fase más antigua, cuando el trellis ha dejado de ser una sucesión de hojas y flores para convertirse en un tallo vegetal con sus correspondientes ensanchamientos y hojas que salen de ellos, tal vez por influencia de las decoraciones de zarcillos vegetales. Esta influencia se hace más patente por el hecho de que los tallos que constituyen el enrejado base no se limitan a cruzarse unos por delante de otros, sino que van enlazados entre sí, formando nudos; cada tallo hace zig-zag y anuda con los más próximos. El enrejado así formado no es por tanto una sucesión inorgánica de hojas y flores, sino un conjunto de tallos vegetales fuertemente enlazados. Las hojas que salen de los engrosamientos de los tallos se encuentran también en los mosaicos con zarcillos, no en los decorados con trellis vegetal.» (Abad Casal, 1982: 368).

Se trata de una retícula muy original de la que no hemos encontrado de momento paralelos exactos. Guirnaldas con una sucesión de tallos y flores en espiral aparecen, entre otros, en el pórtico del templo de Isis en Pompeya (Ranieri, 2004: 288-289). Retículas formadas por sucesiones de motivos son bastante frecuentes en el mundo romano: Domus Aurea (Sciortino y Segala,1999: 80), Villa di Arianna (Stabies) (Formoso, 2006: 87), villa de Popea en Oplontis, Villa de Minori (Laken, 1998: 297 y 395), Domus de las columnas rojas de Sísapo (Hevia et al., 2004: 473) etc. y también en momentos mucho más tardíos como es el caso del apodyterium de Qusayr' Amra construido en el siglo VIII (VibertGuigue, 2004: 210-213; Manzano, 2007: 339) .

${ }^{75}$ Beltrán de Heredia et al., 2007: 107

${ }^{76}$ Catacumbas de Domitila (Giuliani, 2002: 27). 
que estas aves asumen el significado específico del símbolo de la resurrección, mientras el vaso alude a la copa de la inmortalidad ${ }^{77}$.

Aunque no podemos obviar que las representaciones de flores, frutos y aves son también habituales de las pinturas y los mosaicos de las villae ${ }^{78}$.

Si tenemos en cuenta lo que apunta Utrero sobre la reutilización de piezas romanas en la cimentación y la fábrica del primer edificio (Utrero, 2006: 143), así como otros aspectos relacionados con su construcción que hemos comentado más arriba, resulta difícil seguir manteniendo la hipótesis de que el origen del monumento se remonta a época romana. En cuanto a la fase decorativa, existen abundantes paralelos que lo relacionan con el mundo asturiano, pero también con modelos orientales, como sucede con la decoración de placas de mármol. Sin embargo, si aceptamos que esta decoración la hemos considerado una reforma del primer edificio tendríamos que adelantarla a la fecha del siglo IX en la que se encuadran los modelos asturianos.

Quizás detrás del problema de Santa Eulalia se encierran otros de mayor envergadura, por un lado la escasez de estudios de la arquitectura altomedieval gallega desde un punto de vista arqueológico, de manera que podamos establecer contextos bien definidos funcional y cronológicamente, sobre una base estratigráfica, para un período que

\footnotetext{
77 Aunque la interpretación del simbolismo de ciertos elementos dificulta el encuadre de algunas pinturas en un mundo pagano o cristiano o de transición entre ambos. Como ejemplo podemos anotar que para los romanos, los pavos estaban relacionados con la diosa Juno y el mausoleo de Adriano contaba con dos magníficos ejemplares de bronce dorado que, posteriormente, se apropiaron los Papas y en la Edad Media estaban decorando la fontana exterior de la Basílica de San Pedro (Opper, 2008: 210).

Son innumerables y de amplia cronología las representaciones de pavos, casi siempre afrontados con un recipiente entre ambos, del que, a veces, picotean la fruta: tumba del Banquete en Constanta, Rumanía (Chera, 1996: 338); en la Rue Saint-Patrice de Bayeux (Amadei-Kwifati y Bujard, 2007: 423), tumba 25 de la necrópolis de la Isola Sacra; tumba de Via Portuense; tumba en Silistra, Bulgaria (Baldassarre et al., 2006: 52, 314 y 365); en el mausoleo de Marcus Clodius Hermes en San Sebastiano; en el ninfeo-hipogeo de Via Livenza; en el hipogeo de los Flavios (Portella, 2000: 106, 206, 213), en el hipogeo de Via Dino Compagni (Giuliani, 2002: 14) en Roma, etc.

${ }_{78}$ Aparte de las incomparables pinturas pompeyanas o de las magníficas decoraciones de la villa de Livia, la Domus Aurea, la Villa Piccola, bajo San Sebastiano o la domus bajo Santi Giovanni e Paolo en Roma (Portella 2000: 202-205; V.V.A.A. 2006: 8-9), etc., una decoración de hojas lanceoladas alternando con un gallito y un carbonero se conserva en la villa de Valdonega en Verona (Baldassarre et al., 2006: 191) y también son frecuentes en provincias las decoraciones con estos temas: pavos y jarrones con frutas aparecen en decoración mural en villae, como sucede en Newport en la Isla de Wight (Johnston, 2004: 37), pájaros sobre ramas en la Casa del Mitreo de Mérida; flores en el peristilo de la Domus Oceani de Lugo En mosaico, se representan pavos en la villa de Bignor (Johnson, 1995: 35) y en la casa de Fortunatus en Fraga aparecen diversas figuras, pájaros y frutos (Fernández-Galiano, 1987: 212). En el santuario de la villa romana de Milreu (Teichner, 2006: 213) se conservan ladrillos con decoraciones similares: pavos afrontados, jarrones, etc.
}

se encuadra entre la tardorromanidad y la Alta Edad Media. Por otro, la ausencia de estudios complementarios que permitan obtener indicadores cronológicos fiables. Y, finalmente, la pervivencia de unas técnicas constructivas romanas durante un periodo bastante prolongado que pueden haber llevado a interpretaciones erróneas.

«Pero no es solamente la arqueología la que nos puede hacer valorar más el papel que la ciudad [Lugo] jugó en tempos pretéritos, puesto que el estudio de las fuentes escritas, sean literarias o de otra índole, no está ni mucho menos acabado, pueden reinterpretarse de nuevo y pueden y deben ser el complemento de los objetos materiales que se arrancan del subsuelo.

Al mismo tiempo, se hace necesario revisar viejos conceptos historiográficos que, de tan manidos, se convirtieron poco menos que en dogmas de fe. Me refiero en concreto a dos que pueden afectar directamente a nuestra visión del pasado remoto de la ciudad: la llamada crisis del siglo III y los tintes de decadencia y ocaso que siempre fueron unidos indisolublemente a expresiones tales como Bajo Imperio. Y digo esto porque puede pasar que sean esas, y las inmediatamente posteriores, las etapas más brillantes de la historia remota de Lucus» (Novo Güisán, 2003: 205-206).

No queremos terminar este texto sin hacer mención al estado de conservación del edificio y en particular de las pinturas. Desde su descubrimiento se realizaron numerosas intervenciones, sobre todo encaminadas a preservar la pintura del aula. Sin embargo, algunas de ellas fueron poco afortunadas y aportaron casi más problemas de los que resolvieron; sin duda la más nefasta fue la intervención de González Trigo ${ }^{79}$, cuyo objetivo fue eliminar el agua en un edificio creado para el agua y acabar así con la «piscina de aguas inagotables», como la definió Abad Casal (1979: 917). En la actualidad, aunque se observan numerosas fisuras y abrasiones de la película pictórica y del enlucido, que dejan a la vista las arenas del mortero, en general, la pintura está bien adherida al sustrato. Está parcialmente colonizada, pero sin duda la patología más grave y activa es la formación de escamas originada por la acción de los sulfatos procedentes de los hormigones y cuya cristalización está posiblemente potenciada por el corte del muro $\mathrm{N}$ realizado en la intervención de $1985^{80}$.

\footnotetext{
${ }^{79}$ Es lamentable que desde los servicios técnicos de la Dirección General del Patrimonio Artístico y Cultural no sólo se aprobase la intervención destructora e irreversible, sino que, obligaron al arquitecto a realizar una recreación totalmente improcedente, cuando él había propuesto una protección bastante respetuosa con la ruina y que mejoraría su ventilación.

${ }^{80}$ Un informe más detallado sobre el estado de conservación se puede ver en Benavides y Blanco-Rotea, 2008.
} 


\section{Bibliografía}

Abad Casal, L. 1979, Aportación al estudio de Santa Eulalia de Bóveda, Congreso Nacional de Arqueología 1979, Zaragoza, pp. 917-921.

Abad Casal, L. 1982, La pintura romana en España, 2 vol, Universidades de Sevilla y Alicante, V.1 pp. 147-152; 368-370; 384-386; 404; 410-413 y 439448; v. 2 pp. 103-106.

Acuña Castroviejo, F. 1973, Galicia romana: Artes plásticas, Tesis Doctoral, Universidad de Santiago de Compostela, pp. 213-219, 248, 284-290 y 294295.

Aitken, M. J. 1985, Thermoluminescence dating, London.

Aitken, M. J. 1998, An Introduction to Optical Dating, Oxford.

Allag, C. y Barbet, A. 1972, Techniques de preparation des parois dans la peinture murale romaine, Mélanges de l'Ecole française de Rome, Antiquité, Vol. 84, pp. 935-1070.

Amadei-Kwifati, B. y Bujard, S. (Guiral Pelegrín, C. ed.) 2007, Les peintures de la rue Saint-Patrice à Bayeux (Calvados), Circulación de temas y sistemas decorativos en la pintura mural antigua, Actas del IX Congreso Internacional de la Association Internationale pour la Peinture Murale Antique, ZaragozaCalatayud 2004, pp. 423-426.

Ares Vázquez, N. 1962, Santa Eulalia de Bóveda. Dos lisiados y un monasterio, Boletín de la Comisión de Monumentos Históricos y Artísticos de Lugo, T. VII, no 57-58, pp. 115-123.

Ares Vázquez, N. 1963, Santa Eulalia de Bóveda. Mensaje de la cigüeña, Boletín de la Comisión de Monumentos Históricos y Artísticos de Lugo, T. VII, no 59-60, pp. 173-182.

Ares Vázquez, N. 1964, Santa Eulalia de Bóveda. Otro relieve en el pórtico, Boletín de la Comisión de Monumentos Históricos y Artísticos de Lugo, T. VII, no 61-62, pp. 237-246.

Ares Vázquez, N. 1984, Inscripciones lucenses medievales en verso, Boletín del Museo Provincial de Lugo, T. II, pp. 119-134.

Arias 1992: falta (v. nota 70)

Arias Páramo, L. 1999, Prerrománico Asturiano. El arte de la Monarquía Asturiana, Gijón.

Arias Vilas, F. 1980, Santa Eulalia de Bóveda, Museo Provincial de Lugo y Ministerio de Cultura, Lugo.

Fontaine, J. 1978, El Prerrománico, Madrid.

Baker, G.H. 1998, Análisis de la forma: urbanismo y arquitectura, México.

Baldassarre, I., Pontrandolfo, A., Rouveret, A. y Salvadori, M. 2006, Pittura romana. Dall'ellenismo al tardo-antico, Milano.

Barbet, A. 2003, Les décors centrés en mosaïque et leur écho en peinture murale, Revue Archeologique, n. ${ }^{\circ}$ 2, pp. 319-330.

Barral i Altet, X. 2003, La Alta Edad Media. De la Antigüedad Tardia al Año Mil, Köln.

Beltrán de Heredia Bercero, J., Burjachs Casas, F., Expósito Barea, I., Tresserras Juan, J. y Matamala, J.C. 2007, Estudio del «jardín» funerario de la necrópolis de la Plaza de la Vila de Madrid a partir de las investigaciones arqueobotánicas, Quaderns d'Arqueologia i història de la ciutat de Barcelona, n. ${ }^{\circ} 3$, pp. 103 113.

Benavides García, R. 2002, Memoria de los trabajos de documentación y conservación de las pinturas murales romanas del yacimiento arqueológico de la calle Doctor Castro 20-22 de la ciudad de Lugo, Informe inédito depositado en los Servicios Técnicos de la Dirección Xeral de Patrimonio, Consellería de Cultura, Xunta de Galicia.

Benavides, R. y Blanco-Rotea, R. 2008, Mirando cara o futuro: coñecer para conservar, Montenegro et al. 2008, Santa Eulalia de Bóveda, Santiago de Compostela, pp. 43-82.

Caballero Zoreda, L., Arce, F. y Utrero, M. a A. 2004, La iglesia de San Torcuato de Santa Comba de Bande (Orense): Arqueología de la Arquitectura, Archivo Español de Arqueología 77: 273-318.

Caballero Zoreda, L. y Arce Sainz, F. 2007, Producción decorativa y estratigrafía, Caballero Zoreda, L. Y Mateos Cruz, p. (eds.) 2007, Escultura decorativa tardorromana y altomedieval en la península Ibérica, Anejos de Archivo Español de Arqueología, XLI, pp. 233-274.

Caballero Zoreda, L., Mateos Cruz, P. y Utrero Agudo, M.a A. (Eds.) 2009, El siglo VII frente al siglo VII: arquitectura, Anejos de Archivo Español de Arqueología, LI.
Cabarcos Fernández, I. 2005, Bases, fustes e capiteis. Catálogo de elementos columnarios medievais no Museo Provincial de Lugo, Lugo.

Cabrera Garrido, J.M. 1992, Santa Eulalia de Bóveda. Informe relativo al estado de la piedra y a las actuaciones necesarias para su conservación, informe inédito.

Castillo López, A. del 1932, La Arquitectura en Galicia, Geografía General del Reino de Galicia, Barcelona, pp. 849-851.

Chamoso Lamas, M. 1952, Sobre el origen del monumento soterrado de Santa Eulalia de Bóveda (Lugo), Cuadernos de Estudios Gallegos, t. XXII, pp. 231-251.

Chera, C. 1996, Stratigraphische und chemische analyse der muster von wandmalereien aus der Scythia Minor, Béarat, H., Fuchs, M., Maggetti, M. y D. Paunier, D. (Ed.) 1997, Roman Wall Painting. Materials, Techniques, Analysis and Conservation, Proceedings of the International Workshop, Fribourg 7-9 March 1996, Friburgo, pp.337-345.

Collins, R. (Lynch, J. dir.) 2007, Los Visigodos, Madrid.

Croisille, J.M. 2005, La peinture romaine, Paris.

Cruz Villalón, M. 2007, Aplicación metodológica al estudio de la escultura. El conjunto visigodo de Extremadura, Caballero Zoreda, L. y Mateos Cruz, P. (eds.) 2007, Escultura decorativa tardorromana y altomedieval en la península Ibérica, Anejos de Archivo Español de Arqueología, XLI, pp. 221-232.

Elert, K., Rodriguez-Navarro, C., Sebastian Pardo, E, Hansen, E. y Cazalla, O. 2002, Studies in Conservation 47, pp. 62-75

Feijoo Martínez, S. y Rúa Carril, V. 1995, La iglesia perrománica de San Martín de Prado en Lalín, Pontevedra-España, Informes de la Construcción 435, pp. 91-100.

Fernández-Galiano Ruiz, D. 1987, Mosaicos romanos del Convento Cesaraugustano, Zaragoza.

Formoso, E. 2006, Les décors à reseau. Des peintures murales surprenantes et méconnues, La peinture Antique, Dossiers d'Archeologie, no 318, pp. 86-89.

Galbraith, R.F. et al. 1999. Archaeometry, 41, pp. 339-364.

Galindo Díaz, J. A. 1996, El conocimiento constructivo de los ingenieros militares del siglo XVIII. Un estudio sobre la formalización del saber técnico a través de los tratados de arquitectura militar, Tesis doctoral en línea, disponible en http://www.tdr.cesca.es/TESIS UPC/AVAILABLE/TDX1014102-085840//01TESIS.pdf (consulta: 01/05/2009).

García de Castro Valdés, C. 2007, La escultura arquitectónica en el área central del Reino de Asturias: tipos, tradiciones y tendencias, Caballero Zoreda, L. y Mateos Cruz, p. (eds.) 2007, Escultura decorativa tardorromana y altomedieval en la península Ibérica, Anejos de Archivo Español de Arqueología, XLI, pp. $85-132$.

García y Teijeiro, M. 1933, Un vistazo al subter-templo de Santa Eulalia de Bóveda sito en tierras de Mera de Lugo, Artes Gráficas Gerardo Castro, Lugo.

Giuliani, R. (coord.) 2002, La conservazione delle pitture nelle catacombe romane. Acquisicioni e prospettive, Scavi e Restauri 1, Città del Vaticano.

Goedicke, C. 2003, Radiation Measurements, 37, pp. 409-415

Gómez-Moreno Martínez, M. 1949, Santa Eulalia de Bóveda, Misceláneas, Historia-Arte-Arqueología, Primera Serie. La Antigüedad, Madrid, pp. 415-423.

Guardia, M. 2003, El Santuario romano de Bóveda en su ornamentación pictórica, Semata, no 14, pp. 253-76.

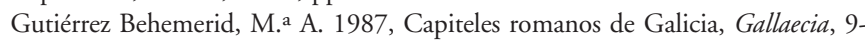
10 , pp. 261.

Heinemeier, J., Jungner, H., Lindroos, A., Ringbom, A., Konow, T. von y Rud, N. 1997, Nuclear Instruments and Methods in Physics Research B 123, pp. $487-$ 495

Hevia Gómez, P., Corral Díaz, R.M., Sierra Sáiz, N. (Guiral Pelegrín, C. ed) 2007, Excavación y restitución de las pinturas del viridarium de la Domus de las Columnas Rojas de Sisapo, Circulación de temas y sistemas decorativos en la pintura mural antigua, Actas del IX Congreso Internacional de la Association Internationale pour la Peinture Murale Antique, Zaragoza-Calatayud 2004, pp.471-474.

Johnson, P 1995, Romano-British Mosaics, UK.

Johnston, D. E. 2004, Roman Villas, UK.

Laken, L. 1998, Wallpaper patterns in Pompeii and the Campanian Region: towards a fifth pompeian style?, Barbet, A (dir.) 2001, La peinture funéraire antique, París, pp. 295-300.

López-Martí Castillo, L. 1927, Los descubrimientos de Santa Eulalia de Bóveda, Boletín de la Real Academia Gallega, T. XVII, nº 194, pp. 57-62. 
López-Martí Castillo, L. 1928, Los excavaciones de la iglesia de Santa Eulalia de Bóveda, Boletín de la Real Academia Gallega, T. XVII, no 204, pp. 322-326.

López-Martí Castillo, L. 1934, Santa Eulalia de Bóveda. Descripción y gráficos del monumento allí existente, Junta del Museo Provincial de Lugo, $\mathrm{n}^{\circ} 1$.

Manzano, E. (Lynch, J. dir.) 2007, La expansión de los musulmanes en la Peninsula, Madrid.

Mañana-Borrazás, P., Rodrígue Paz, A., Blanco-Rotea, R. 2008, Una experiencia en la aplicación del Láser Escáner 3D a los procesos de documentación y análisis del Patrimonio Construido: su aplicación a Santa Eulalia de Bóveda (Lugo) y San Fiz de Solovio (Santiago de Compostela), Arqueología de la Arquitectura, 5, pp. 15-32.

Martínez Morás, F. 1927, Los hallazgos de Bóveda. Nuevos descubrimientos, Boletin de la Real Academia Gallega, T. XVI, n. ${ }^{\circ}$ 191, pp. 267-272.

Montenegro Rúa, E. J. 2005, El descubrimiento y las actuaciones arqueológicas en Santa Eulalia de Bóveda (Lugo), Lugo.

Montenegro Rúa, E. J. 2008, O monumento de Santa Eulalia de Bóveda, Síntese da súa historia coñecida, Montenegro et al. 2008, Santa Eulalia de Bóveda, Santiago de Compostela, pp. 11-40.

Montenegro et al. 2008, Santa Eulalia de Bóveda, Santiago de Compostela.

Murray, A. S. y Wintle, A. G. 2000, Radiation Measurements, 32, pp. 57-73

Novo Güisan, J.M. 2003, Lugo nos tempos escuros. As mencións literarias da cidade entre os séculos V e X (e IX), Boletín do Museo Provincial de Lugo, XIII 2006/2007/2008, 2009, pp. 205-207.

Nunes Pedroso, R. 1998, La «Basilique» de Tróia. Un décor luso-romain du ivo s. ap. J.-C., Barbet, A (dir.) 2001, La peinture funéraire antique, París, pp. $305-$ 308 y 397.

Nunes Pedroso, R. 2006, Réseaux, plantes et marbres. Une importante peinture luso-romaine du iv ${ }^{e}$ s. ap. J.-C., La peinture Antique, Dossiers d'Archeologie, $n^{o}$ 318, nov-dec. 2006, pp. 70-75.

Núñez Rodríguez, M. 1978, Historia da arquitectura galega. Arquitectura prerrománica, Santiago de Compostela, pp. 113-117 y 131-139.

Opper, T. 2008, Hadrian Empire and Conflict, Catálogo de la exposición, The British Museum Press, London.

Palladius (Rutilius Taurus Aemilianus): De re rustica, [en línea], <http:// http:// www.culturaapicola.com.ar/wiki/index.php/Palladius $>$, [última consulta: $20 /$ 07/2009]

Palol, P. de y Ripoll, G. 1988, Los godos en el occidente europeo. Ostrogodos y Visigodos en los siglos V-VIII, Madrid.

Pérez Losada, F. 1992, Hipocaustos na Galicia Romana, Gallaecia, 13, pp. 129176.

Portela Fernández-Jardón, C. y Gallego Jorreto, J. M. 1990, Restauración. Santa Eulalia de Bóveda - Lugo, (Proyecto inédito), A Coruña.

Portella, I. della 2000, Subterranean Rome, Könemann, Germany.

Ranieri Panetta, M. 2004, Pompeya: historia, vida y arte de la ciudad sepultada.

Roberts, R. G. 1997, Radiation Measurements, 27, pp. 819-892

Rodríguez Colmenero, A. 1992, Culto a las aguas y divinidades orientales en el Lugo romano: los monumentos de Bóveda y San Roque, Espacio, Tiempo y Forma, Serie II, Ha Antigua. Termalismo antiguo. Actas de la mesa redonda Aguas mineromedicinales, termas curativas y culto a las aguas en la Península Ibérica, t. v, pp. 309-335.

Rodríguez Colmenero, A. 1993, Arte e proceso urbanizador, En Rodríguez Iglesias, F. 1993, Galicia Arte, T. IX, Arte Prehistórica e Romana, A Coruña, pp. 288-341.

Rodríguez Colmenero, A. 1993, Pintura e mosaico, En Rodríguez Iglesias, F. 1993, Galicia Arte, T. IX, Arte Prehistórica e Romana, A Coruña, pp. 344-371.

Rovira Lloréns, S. (ed.) 2007, VII Congreso Ibérico de Arqueometría, Actas [recurso electrónico].
Singul Lorenzo, F. L. 1997, La pintura de Santa Eulalia de Bóveda (Lugo) Ortodoxia y clasicismo en la pintura paleocristiana del Noroeste hispánico, Boletin Auriense, T. 27, pp. 175-193.

Singul Lorenzo, F. L. 1998, La pintura de Santa Eulalia de Bóveda (Lugo): significado y relaciones con el arte paleocristiano y la pintura asturiana. Ortodoxia y clasicismo en la pintura paleocristiana del Noroeste hispánico, Boletin Auriense, T. 28, pp. 59-84.

Schlunk, H. 1935, Santa Eulalia de Bóveda, Das Siebente Jahrzent. Festschrift für A. Goldschmidt, pp. 1-13. Berlin.

Schlunk, H. y Berenguer, M. 1991, La pintura mural asturiana de los siglos IX y X. Oviedo: Servicio Central de Publicaciones del Principado de Asturias.

Sciortino, I., Segala, E. 1999, Domus Aurea, Milano.

Teichner, F. (2006): «De lo romano a lo árabe». La transición del sur de la provincia Lusitania a Al-Gharb Al-Andalus. Nuevas investigaciones en los yacimientos de Milreu y Cerro da Vila", Chavarría, A. et al. (eds.), Villas Tardoantigua en el Mediterráneo Occidental, Anejos de AEspA XXXIX, pp. 207-220.

Tortorella, S. 2007, Riflessioni sui temi della pittura funeraria romana, Guiral Pelegrín, C. (ed) 2007, Circulación de temas y sistemas decorativos en la pintura mural antigua, Actas del IX Congreso Internacional de la Association Internationale pour la Peinture Murale Antique, Zaragoza-Calatayud 2004, pp.103-111.

Utrero Agudo, M.a Á. 2006, Iglesias tardoantiguas y altomedievales en la península Ibérica. Análisis arqueológico y sistemas de abovedamiento, Anejos de Archivo Español de Arqueología, XL.

Varela Arias, M. ${ }^{\text {a }}$ E. 1984, La escultura medieval en el Museo Provincial de Lugo: Ensayo de Catalogación, Tesis de Licenciatura inédita, Santiago de Compostela, pp. 27-29.

Vendrell-Saz, M., Alarcón, S., Molera, J., García-Vallés, M. 1996, Archaeometry, 38, pp.143-149.

Vidal Caeiro, L. 2003, Santa Eulalia de Bóveda: Análisis de los ladrillos, Gallaecia, 22, pp. 225-252.

Vidal Caeiro, L. 2006, Arqueología de Santa Eulalia de Bóveda, III Premio de investigación Manuel Vázquez Seijas, Lugo, pp. 11-122.

Vitrubio: Los diez libros de arquitectura, Traducción de José Ortiz y Sanz 1787, Reproducción facsímil 1992, Madrid.

Vivert-Guigue, C. 2007, L’adaptation de décors antiques à l'époque omeyyade au Proche-Orient, Guiral Pelegrín, C. (ed), Circulación de temas y sistemas decorativos en la pintura mural antigua, Actas del IX Congreso Internacional de la Association Internationale pour la Peinture Murale Antique, ZaragozaCalatayud 2004, pp.209-216.

V.V.A.A. 1985, Le décor géométrique de la mosaïque romaine, París.

V.V.A.A. 2006, Case Romane e Antiquarium sotto la Basilica dei Ss. Giovanni e Paolo al Celio, Roma.

V.V.A.A. 2007, Caracterización de la composición y estructura de pigmentos decorativos de épocas romana, islámica y moderna de excavaciones arqueológicas de la ciudad de Sevilla mediante técnicas arqueométricas, Rovira Lloréns, S. (ed.) 2007, VII Congreso Ibérico de Arqueometría, Actas [recurso electrónico], pp. 688-699.

Yzquierdo Perrín, R. 1993, Galicia Arte. Tomo X. Arte medieval, A Coruña, pp. 107-108.

Zacharias, N., Mauz, B., Michael, C.T. 2002, Radiation Protection Dosimetry, 101, pp. 379-382.

Recibido : 31 de agosto de 2009

Aceptado : 26 de octubre de 2009 